Review

\title{
Specific control of cell-material interactions: Targeting cell receptors using ligand-functionalized polymer substrates
}

\author{
Andrew E. Rodda a,b,c Laurence Meagher $^{\mathrm{b}, \mathrm{c}}$, David R. Nisbet ${ }^{\mathrm{d}}$, \\ John S. Forsythe ${ }^{a, c, *}$ \\ a Monash University, Department of Materials Engineering, Wellington Road, Clayton 3800, Victoria, Australia \\ b CSIRO Materials Science and Engineering, Bayview Avenue, Clayton 3168, Victoria, Australia \\ c Cooperative Research Centre for Polymers, 8 Redwood Drive, Notting Hill 3168, Victoria, Australia \\ d School of Engineering, The Australian National University, Canberra 0200, Australian Capital Territory, Australia
}

\section{A R T I C L E I N F O}

\section{Article history:}

Received 8 July 2013

Received in revised form

18 November 2013

Accepted 26 November 2013

Available online $\mathrm{xxx}$

\section{Keywords:}

Conformation

Orientation

Bioconjugation

Attachment

Immobilization

Bio-orthogonal

\begin{abstract}
A B S T R A C T
Cells respond to their environment in complex and sometimes poorly understood ways. Protein, peptide and synthetic peptidomimetic ligands may all be used to stimulate cells via receptor signaling, using interactions that are often highly specific. Polymer substrates that present these ligands provide a promising way to control cell development, both for applications in biotechnology and for fundamental studies of cell biology. Here we review a large range of techniques that have been employed to create and characterize ligandfunctionalized substrates, with a particular focus on techniques that allow specific and consistent stimulation.
\end{abstract}

(c) 2013 Elsevier Ltd. All rights reserved.

Abbreviations: 2D/3D, two/three dimensional; AA, amino acid; AFM, atomic force microscope/microscopy; ATRP, atom transfer radical polymerization; BCA, bicinchoninic acid; bFGF, basic fibroblast growth factor; BSA, bovine serum albumin; CAM, cell adhesion molecule; CDI, 1,1' carbonyldiimidazole; CNTF, ciliary neurotrophic factor; CTA, chain transfer agent; CuAAC, copper-mediated azide-alkyne click (reaction); DPN, dip-pen nanolithography; EBL, electron beam lithography; ECM, extracellular matrix; EDC/NHS, $N$-(3-dimethylaminopropyl)- $N$-ethylcarbodiimide with $N$-hydroxysuccinimide activation; EGF, epidermal growth factor; ELISA, enzyme-linked immunosorbent assay; ERK/MAPK, extracellular signal regulated kinase/mitogenactivated protein kinase; FGF, fibroblast growth factor; FRET, Förster resonance energy transfer; GAG, glycosaminoglycan; GF, growth factor; GNP, gold nanoparticle; His-6, hexahistine; HPLC, high performance liquid chromatography; IPN, interpenetrating polymer network; IR, infrared; L-DOPA, L-3,4-dihydroxyphenylalanine; LbL, layer-by-layer (deposition); LIF, leukaemia inhibitory factor; MMP, matrix metalloproteinase; nCP, nanocontact printing; NGF, nerve growth factor; NMP, nitroxide-mediated polymerization; NMR, nuclear magnetic resonance spectroscopy; NTA, nitriloacetic acid; PDMS, polydimethylsiloxane; PEG, poly (ethylene glycol); PI3k, phosphoinositide 3-kinase; QCM, quartz crystal microbalance; RAFT, reversible addition-fragmentation chain transfer; SAM, self-assembled monolayer; SANPAH, $N$-sulfosuccinimidyl-6-(4'-azido-2'-nitrophenyl-amino) hexanoate; SAP, self-assembling peptide; SMCC, succinimidyl-4-( $N$-maleimidomethyl)cyclohexane-1-carboxylate; SPR, surface plasmon resonance; TBTA, tris((1benzyl-1H-1,2,3-triazol-4-yl)methyl)amine; TGF- $\beta$, transforming growth factor beta; ToF-SIMS, time-of-flight secondary ion mass spectrometry; $\mu C P$, microcontact printing; UV, ultraviolet; VEGF, vascular endothelial growth factor; XPS, X-ray photoelectron spectroscopy.

* Corresponding author at: Monash University, Department of Materials Engineering, Wellington Road, Clayton 3800, Victoria, Australia. Tel.: +61 399059609 .

E-mail address: John.Forsythe@monash.edu (J.S. Forsythe). 


\section{Contents}

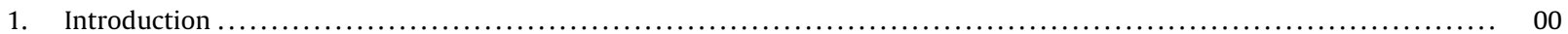

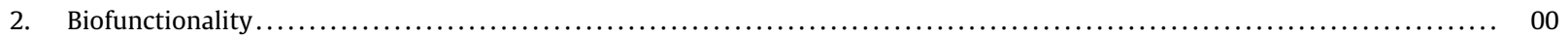

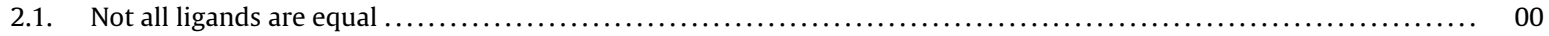

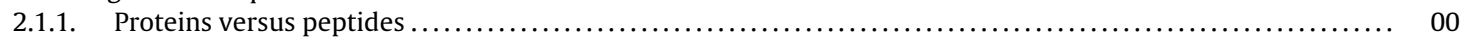

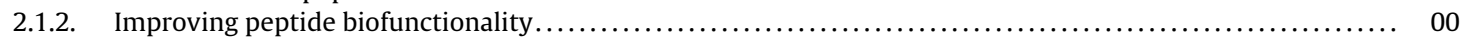

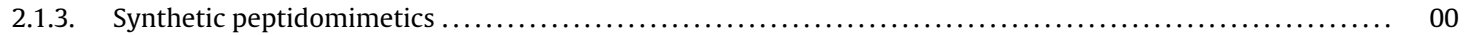

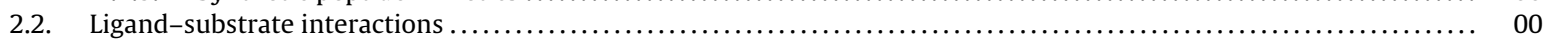

2.2.1. Changes in conformation and binding site accessibility resulting from attachment to substrates .......... 00

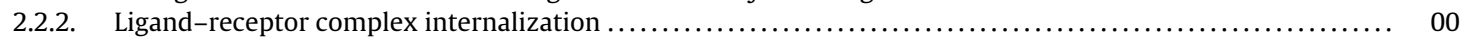

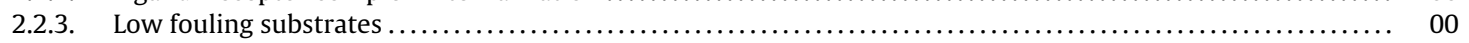

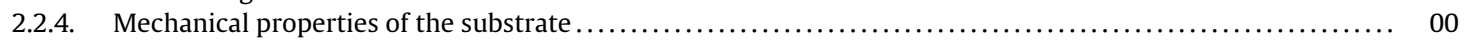

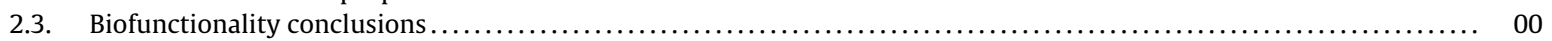

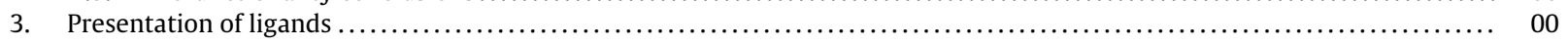

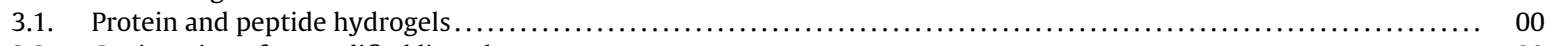

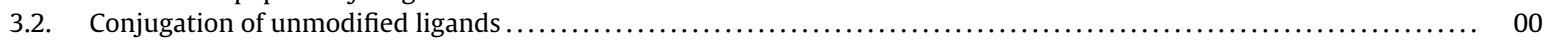

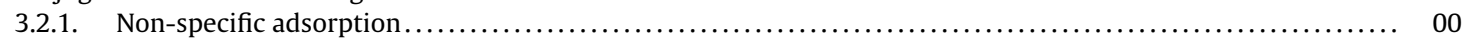

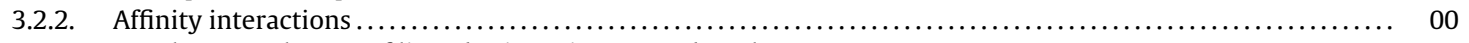

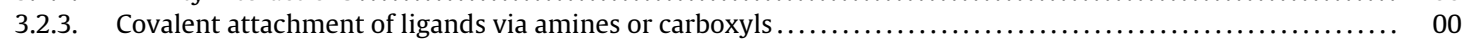

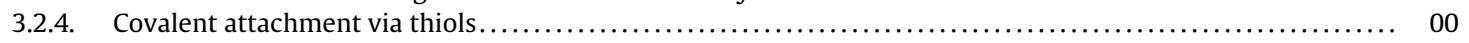

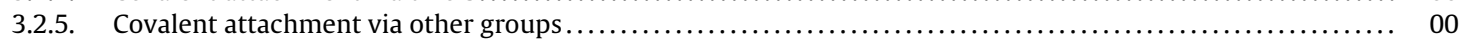

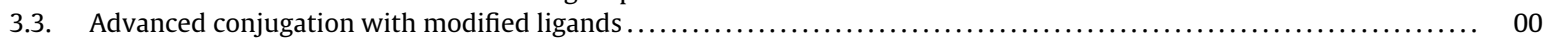

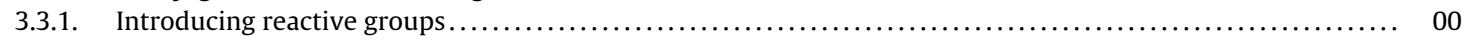

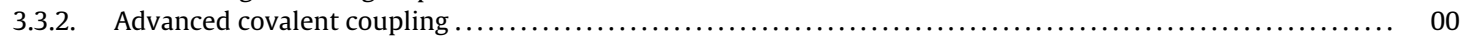

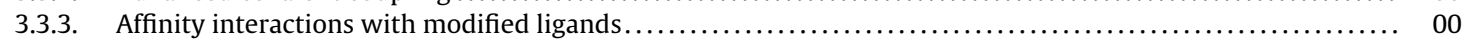

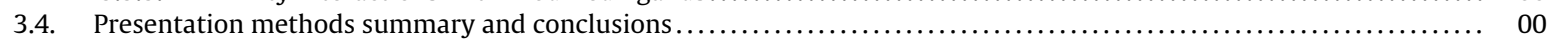

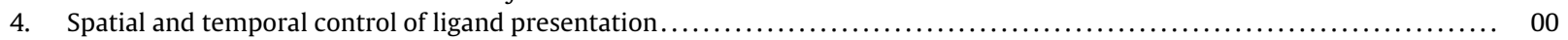

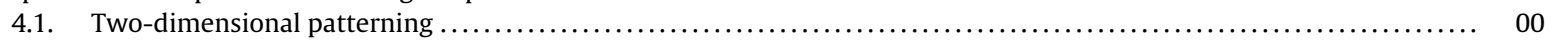

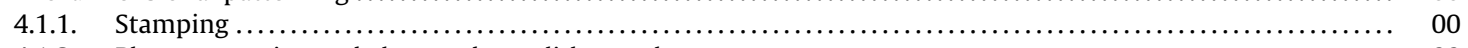

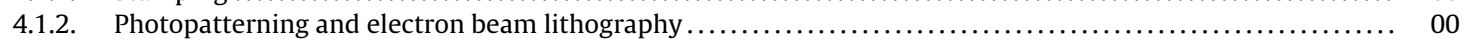

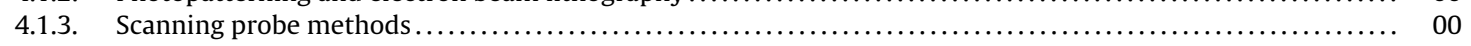

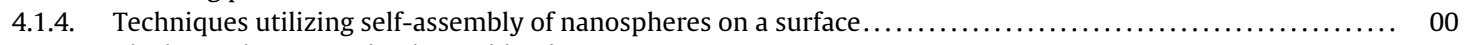

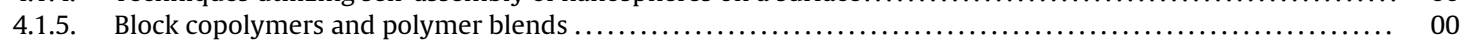

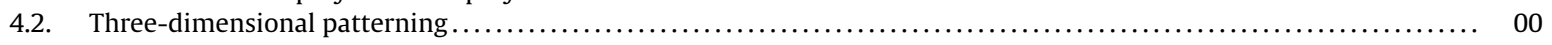

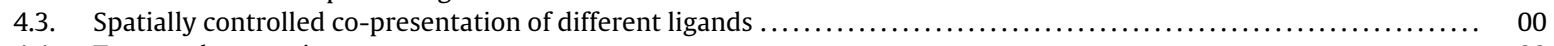

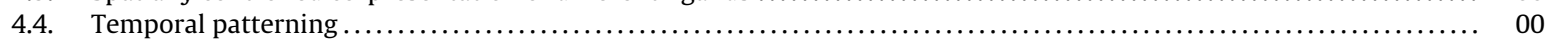

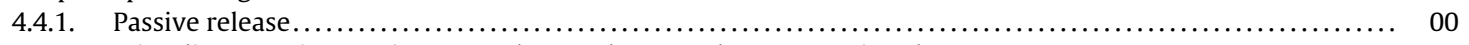

4.4.2. Stimuli responsive spatiotemporal control: researcher-responsive changes $\ldots \ldots \ldots \ldots \ldots \ldots \ldots \ldots \ldots \ldots \ldots$

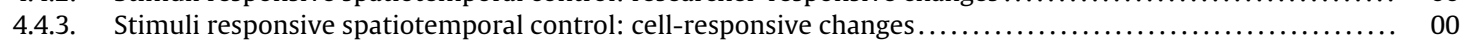

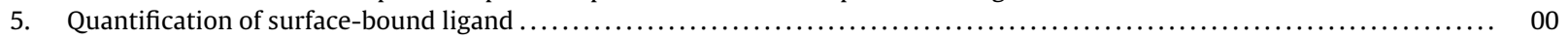

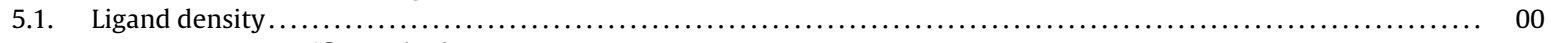

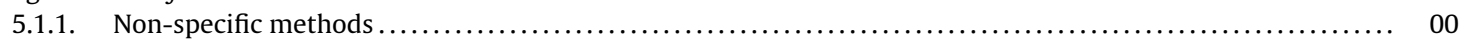

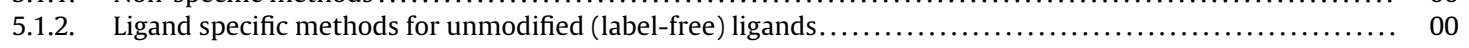

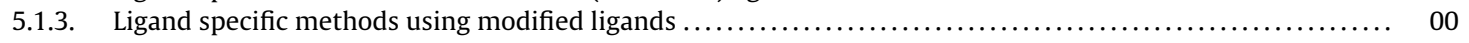

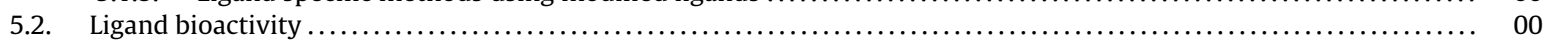

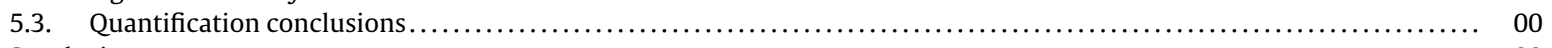

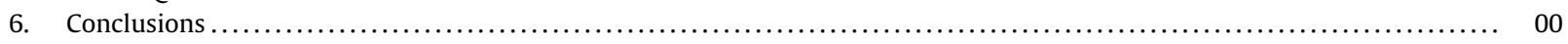

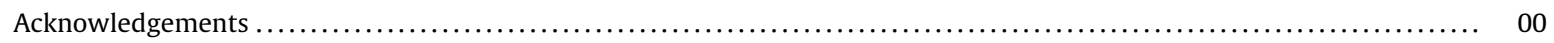

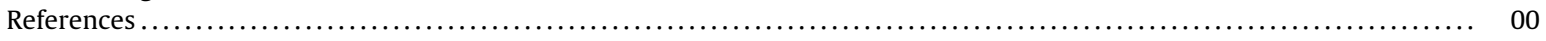

\section{Introduction}

Receptors in the cellular membrane are a vital way in which cells can sense and respond to their local environment. Binding between cell receptors and their ligands, which may include proteins, peptides and synthetic molecules, is tightly controlled by physical, electrostatic and hydrophobic/hydrophilic interactions between the two. These interactions make ligand-receptor binding highly specific and therefore a prime candidate for tightly controlled cell stimulation.

Ligand-functionalized culture substrates are a promising method for achieving this stimulation [1]. The advantages of using functionalized polymer substrates, compared to soluble ligands, vary with circumstance. They may include: receptors requiring a surface-bound ligand for activation (e.g., many adhesion signals); increased receptor stimulation time and concordant increased length of signaling period; ability to control ligand release over a period of time; ability to use smaller amounts of (sometimes quite expensive) ligand; and the ability to achieve continual stimulation in vivo without repeated dosing at high concentrations. Functionalized substrates may also be useful for creating simplified models of the in vivo microenvironment for the study of fundamental biological interactions, reproducible drug toxicology/efficacy 


\begin{tabular}{|ll|}
\hline One letter amino acid codes \\
A & alanine \\
C & cysteine \\
D & aspartic acid \\
E & glutamic acid \\
F & phenylalanine \\
G & glycine \\
H & histidine \\
I & isoleucine \\
K & lysine \\
L & leucine \\
N & asparagine \\
O & hydroxyproline \\
P & proline \\
Q & glutamine \\
R & arginine \\
S & serine \\
T & threonine \\
V & valine \\
Y & tyrosine \\
& \\
\hline
\end{tabular}

screening and for the generation of cells for use in therapy.

In this review we examine the myriad of techniques that have been used to create polymer-based substrates to target specific receptors. Relevant literature from other fields, including non-polymeric substrates, antibody and other diagnostic chips, nanoparticles, and soluble ligands has also been included where appropriate. We attempt to define general principles that can be used to make informed decisions when designing these substrates.

\section{Biofunctionality}

In this section we examine the suitability of different ligands for presentation from cell substrates. We also examine several ways in which attachment of a ligand to a substrate can change that ligand's biofunctionality, often (but not always) for the worse. The discussion here will also serve as background and justification for discussions on presentation methods later in this article.

Here we define a ligand to be biofunctional if it docks with a receptor, affecting downstream signaling. Note that under this definition, ligands may act as agonists (full or partial receptor activation) or antagonists (preventing agonists from binding, thus disabling the receptor). Many ligands can bind to multiple receptors, with each receptor having a different cellular function. Binding of short RGDbased peptides (arginine-glycine-aspartic acid; standard one letter amino acid codes will be used throughout this review) to integrin receptors is a common example; while different integrin receptors are known to have distinct cellular functions, the RGD motif binds to a large number of different receptors $[2,3]$. At the same time, it is important to note that receptors can also complex with multiple ligands; glycoprotein 130, a cytokine receptor, can bind to multiple cytokines, including ciliary neurotrophic factor (CNTF), interleukin-6, and leukemia inhibitory factor (LIF), with each of these interactions producing different cellular outcomes [4].

Direct recommendations of any particular ligand or ligand type over another will not be given here, as in many cases it is up to the researcher to confirm that their ligand of interest is appropriate under their specific conditions. There will also be no tables or lists of ligands that have been previously immobilized: many lists or reviews of this type already exist, e.g., growth factors [5,6], RGD ligands [7,8], and short peptides [9]. While there are many examples using integrin-binding ligands (as a heavily investigated area of research) we aim to show general principles applicable to any signaling cascade.

\subsection{Not all ligands are equal}

\subsubsection{Proteins versus peptides}

When examining cellular interactions with ligandfunctionalized substrates, there can be significant differences between the effects of a full protein and those of a smaller peptide that bears the same motif. This has been particularly investigated in the context of integrin-binding ligands such as RGD; however short peptides also exist that bind to other receptors, such as non-integrin-binding adhesion peptides and growth factor mimics [10-18]. Peptide sequences for non-receptor-binding functions such as growth factor binding peptides or enzymatic degradation sequences will not be discussed here.

For the purposes of this discussion, "peptides" will refer to those amino acid-based materials that are produced (using well-known synthesis protocols) by reacting amino acids (AAs) sequentially. In contrast, proteins are usually longer sequences that are either extracted or produced recombinantly. We recognize that alternative definitions are possible, and that some sequences of intermediate length may be produced by either method; in these cases, the functional properties of the resulting polypeptide may not fit cleanly into either category. Excellent recent opinion articles have also examined differences between proteins and peptides $[19,20]$ and Table 1 further examines these differences in detail. Many of the functional differences between proteins and peptides can be described in a single comparison: complexity versus simplicity. However, deciding which of these is appropriate for a given study is a more difficult matter.

Peptides have many practical advantages over proteins: they are more resistant to environmental stresses, such as heat or solvents; they are easier to obtain in a single, chemically pure form; they are usually synthesized to contain only one or a small number of motifs, each with a defined function; and they are more easily modified to a different sequence or to include non-natural amino acids [20]. Peptides may be useful for elucidating the function of various parts of proteins, deconstructing their actions into tractable pieces (see also Section 4.3).

However no peptide system has yet come close to mimicking the well-adapted functional complexity, specificity and affinity of most proteins. Proteins often bind to their receptors with higher affinity than peptides due to well-defined tertiary structure. Proteins such as those found in the extracellular matrix (ECM) can contain large 
Table 1

Comparison of protein versus peptide ligands.

\author{
Proteins (extracted or produced recombinantly) \\ Functionality \\ Binding sites show high specificity. \\ Contain motifs for multiple receptors as well as growth \\ factor-binding sites and other sequences. Probably contain as-yet \\ unrecognised motifs. \\ Motifs may be exposed by mechanical forces or proteolytic \\ degradation. \\ High affinity when correctly folded.
}

Higher order structure from protein folding and dimerisation.

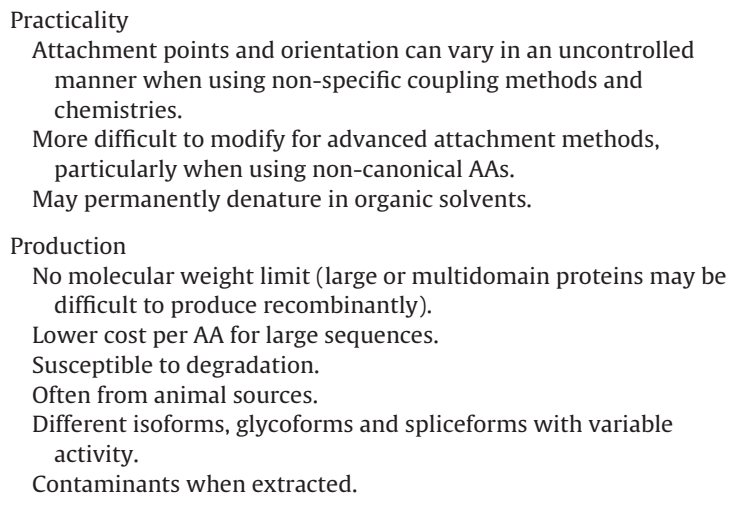

More difficult to modify for advanced attachment methods, particularly when using non-canonical AAs.

May permanently denature in organic solvents.

Production

No molecular weight limit (large or multidomain proteins may be difficult to produce recombinantly).

Lower cost per AA for large sequences.

Susceptible to degradation.

Often from animal sources.

Different isoforms, glycoforms and spliceforms with variable activity.

Contaminants when extracted.

Peptides (synthesised)

Small sequences may bind to multiple receptors, especially when very short, e.g. the tripeptide RGD motif binds to many integrins (although receptor-specific peptides do exist).

Single function per motif, more easily analyzed results. Multiple motifs can be combined using fusion peptides or similar.

No dynamic interactions within current peptide ligands.

Generally lower affinity, although some cyclic peptides can bind strongly.

Variable secondary and higher-order structures. Linear peptides may have more flexible conformation compared to cyclic ones.

Can readily be synthesised with a single functional group or motif for controlled, oriented attachment.

Can be synthesised using amino acids that have protecting groups (for later modification) or non-canonical amino acids.

Resistant to many solvents.

Step-by-step manufacture limits molecular weight.

Lower cost overall.

More stable, particularly when cyclised.

Synthesised.

A single, chemically defined form.

Chemically pure. numbers of functional sites, and in many cases function in ways that are yet to be fully understood. These functional sites can provide not only receptor-binding sequences, but sequences which may be sensitive to protease degradation, which can unfold to reveal "cryptic" binding sites, which sequester growth factors from the surrounding environment, or which modulate structure or mechanical properties of the proteins $[19,21]$, and these may affect receptor signaling. Many receptor-binding proteins also typically exist in glycosylated forms whose interactions are difficult to mimic using simple peptides.

Comparing specificity in proteins and peptides is difficult. Specificity in proteins can vary: while some growth factors commonly bind only to a single receptor, the multifunctional ECM proteins can participate in many simultaneous interactions. While this is advantageous when trying to elicit a strong cellular response, it can also make deconstructive analysis of downstream responses more difficult. In some circumstances, using protein domains may cut down the number of potential interactions, while retaining the higher affinity from the full protein [22,23]. On the other hand, although specific peptide ligands do exist for some receptors, short peptide ligands are often non-specific [19].

\subsubsection{Improving peptide biofunctionality}

Several types of modifications can alter the functional properties of small peptides, giving increased affinity and specificity. These modifications may stabilize the peptide's active site and its surrounding AAs into a conformation that promotes strong binding to the receptor and subsequent activation. However, affinity may be decreased if the peptide is constrained into an unfavorable conformation [24].

Firstly, this can be achieved by adding additional amino acids on either side of the minimal binding motif (see also Fig. 1). As the combination of residues flanking these short motifs is modified, the peptide segment can adopt a more stable tertiary structure, which can increase cell adhesion [25] and specificity for different receptors [7,26] to RGD peptides. Such effects have also been observed for nonRGD ligands: Khew et al. showed that the peptide GFOGER (where $\mathrm{O}$ is hydroxyproline) needed to be presented in a helical formation (similar to collagen, from which the sequence is derived) in order to most effectively bind its target, $\alpha_{2} \beta_{1}$ integrin receptors. This structure was achieved by using longer peptide sequences surrounding the main motif [27].

Secondly, cyclized RGD peptides may also show increased specificity and affinity compared to analogous linear peptides [28], and this can enhance cell responses to biomaterials [29]. Cyclization can also prevent enzymatic degradation [24]. The degree of specificity and affinity of the ligand toward its receptor can be influenced by the number of amino acids, their sequence and use of D-amino acids $[24,30]$. Furthermore, the exact conformation of the cyclic ligand can alter affinity: for example, Assa-Munt et al. examined an RGD peptide that contained 4 cysteine residues, and showed that altering the pairing of the two disulfide bonds within the peptide could cause a tenfold change in its affinity for $\alpha_{v} \beta_{3}$ integrin receptors [31]. 


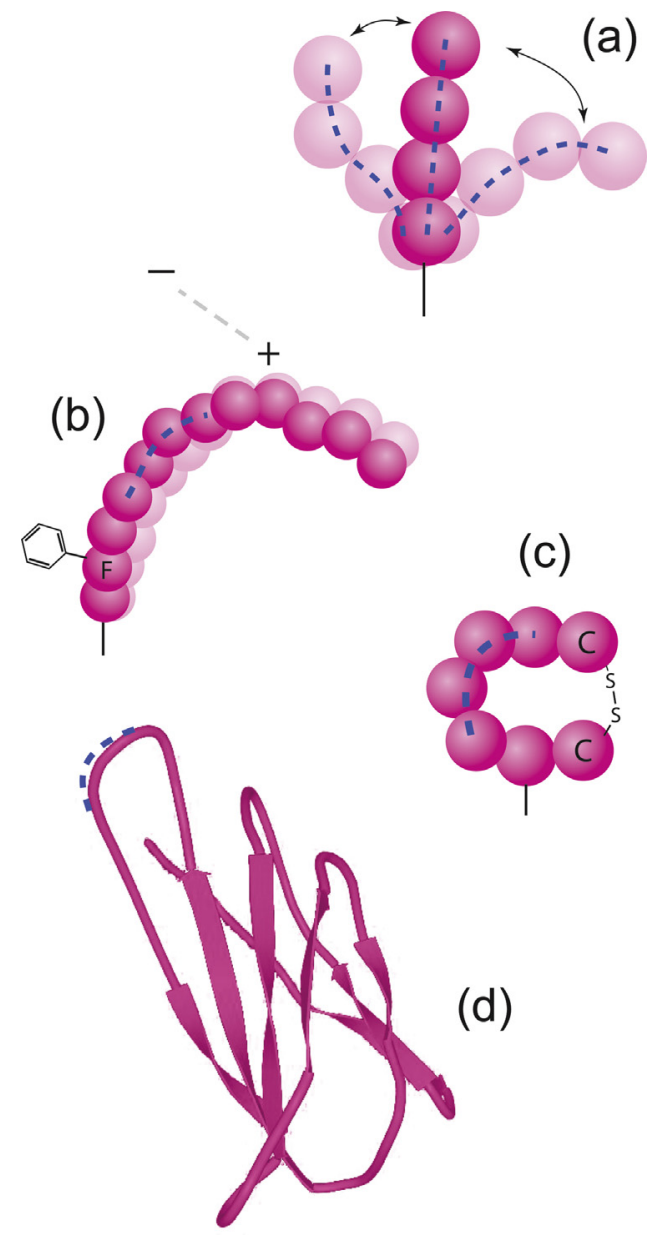

Fig. 1. (a) Minimal binding peptide motifs (e.g. RGD or IKVAV) have decreased affinity and specificity for receptors due to lack of stable structure (binding site conformation shown in blue). (b) Addition of flanking amino acids from the corresponding protein can increase structural stability and potentially induce electrostatic and hydrophobic interactions with the receptor. (c) Small cyclic peptides have very stable structures and can bind with affinities approaching that of whole proteins. (d) Protein domains e.g. the 10th Type III domain from fibronectin (image adapted from Protein Data Bank (reference code 1TTF)) have complex tertiary structure and strong binding to receptors, but are likely to be too large to be made via peptide synthesis. Full proteins (not shown) may have even more subtle interactions, for example involving glycosaminoglycans or the PHSRN synergy sequence in the 9th type III domain. (For interpretation of the references to color in this figure legend, the reader is referred to the web version of the article.)

\subsubsection{Synthetic peptidomimetics}

Receptors may also be activated by ligands that are not based on amino acid sequences. These types of molecules are rarely (and only recently) used for developing cell culture substrates but may be of use due to their potentially high specificity and affinity. Several studies have attached non-peptidic integrin-binding ligands to surfaces and assayed cell attachment [32-36]. Klim et al. modified a streptavidin-coated polystyrene surface with a synthetic compound which, in solution, was highly specific for $\alpha_{v} \beta_{3}$ integrin [33]. They found that attachment occurred almost solely through the $\alpha_{v} \beta_{3}$ integrin receptor, and downstream signaling pathways were activated, with the attached cells forming focal adhesions. Rechenmacher et al. used agonists specific for $\alpha_{v} \beta_{3}$ or $\alpha_{5} \beta_{1}$ integrins to selectively attach fibroblasts that expressed either of these integrins [36].

Although synthetic ligands are commonly used in other research areas, modeling may be required to ensure immobilization maintains the correct orientation and presentation of the binding domain when attached to polymer substrates. This area of research is little explored, but use of these ligands is likely to have several practical benefits, including stability and low-cost synthesis [35]. It is also likely that different reactive groups may be more easily incorporated into synthetic agonists than proteins.

\subsection{Ligand-substrate interactions}

\subsubsection{Changes in conformation and binding site accessibility resulting from attachment to substrates}

Attaching protein ligands to a substrate at multiple points (via adsorption or some covalent methods) can cause loss of biofunctionality through changes in orientation or conformation of the protein [5,37-41]. Importantly, the loss of bioactivity may not be complete, and can vary depending on the combination of attachment points in each individual protein. This makes quantitative studies of receptor activation virtually impossible.

This effect can also be seen in smaller peptides. Salinas and Anseth attached three similar RGD peptides to a polyethylene glycol (PEG) gel [42]. Dual-bound RGD encouraged slightly less cell survival than a singly-bound peptide of similar sequence, and significantly less than a singly-bound peptide with a spacer, possibly due to steric inhibition of binding. Binding a ligand to a surface using an amino acid side chain within the receptor-binding site, such as the lysine residue within an IKVAV peptide, can also prevent or reduce the strength of receptor binding [13].

Short chain molecules, typically based on PEG or polypeptide (often polyglycine) repeat units, are often used as spacers to improve ligand accessibility and prevent issues arising from steric hindrance from the underlying surface $[7,8,43]$. Degradable or stimuli-responsive spacers may also be used to allow release or activation of attached ligand at a later stage (see Section 4.4). There are no general rules on the length of spacer required, as this depends on the properties of the surface, ligand and receptor. Relevant concerns in choosing a spacer may include the location of the binding site on (or within) the receptor, surface roughness, distance of the ligand from the surface without a spacer, and any preference for flexible or rigid orientation of the ligand. A spacer that is too long may also decrease bioactivity; although the exact mechanism is not known, it is possibly due to shielding of the active site (as observed for ligands in solution) or changes in orientation caused by a flexible linker, or a lack of tension being induced during ligand-receptor binding (see Section 2.2.4 for further discussion of the relationship between tension and receptor binding) $[7,44,45]$. Pallarola et al. compared three different spacer types (alkane-, PEG- and polyproline-based linkers) of varying lengths, and showed increased cell binding to the inflexible polyproline spacers. Adhesion increased with spacer length for all types of spacer examined here (1-6 nm), despite shielding being observed from longer 
spacers when binding was measured in solution, prior to attachment on the substrate [45].

\subsubsection{Ligand-receptor complex internalization}

Unlike adhesion ligands, growth factors are often internalized by the cell after they bind to their respective receptors. However, many studies have examined surfaces modified with covalently bound growth factors (that cannot be internalized) and have found that bioactivity may be retained, or altered [1]. In some cases, bioactivity (measured by overall cellular response) was even increased [46-49], possibly due to internalization of the growth factor being prevented [50].

However, care needs to be taken; several studies have shown that preventing internalization can alter or prevent signaling in some pathways, while leaving others unaffected. MacInnis and Campenot used microbeads with covalently coupled nerve growth factor (NGF) to physically prevent NGF internalization by sympathetic neurons [51]. A pro-survival pathway (PI3K/Akt) was activated, but another NGF signaling pathway that is associated with differentiation, ERK/MAPK, was not. Recent studies of interest have examined in detail how covalent linkages can affect the signaling of vascular endothelial growth factor (VEGF) $[52,53]$. Other studies have prevented internalization using various mutated proteins (that are involved in the internalization mechanism), and have also found cases where certain signals depended on internalization, while others did not $[50,54]$.

\subsubsection{Low fouling substrates}

The use of low fouling substrates can prevent several problems that may arise when examining the effects of surface-bound signals. Proteins that non-specifically adsorb on the surface can modify the effect of the ligands of interest that were specifically attached. Receptors may be physically impeded from full access to the ligand under investigation, or alternatively other signaling cascades may modulate or override the intracellular signals of the ligand in question.

In addition, even when covalently tethered at a single position, proteins can still interact non-specifically with the substrate via ionic, hydrogen bonding or hydrophobic interactions, which may alter the protein's conformation $[55,56]$. By reducing the non-specific interactions between a tethered ligand and the substrate, protein resistant surfaces may increase the probability that the ligand of interest is available in a consistent, favorable conformation.

In general, the use of neutral, hydrophilic synthetic materials is the most common way to introduce low fouling properties into a substrate. These materials commonly include PEGs [9], polyacrylamide [57,58], polyglycerol [59], poly(hydroxypropyl methacrylamide/methacrylate) $[60,61]$, poly $(N$-vinyl pyrollidone) [62], or polymers which contain zwitterionic groups such as phosphorylcholines and carboxy- or sulfobetaines [17,63-65]. Naturallyoccurring materials including hyaluronic acid and methyl cellulose have also been used to create thin films with some resistance to protein fouling [66-70]. Low-fouling materials may be used in the bulk (as hydrogels) [9,64,71], or to create surface coatings on other materials.
Many different methods exist with which to create low fouling surface coatings. The most common coating strategies employ the use of self-assembled monolayers (SAMs) comprising alkanethiols or silanes, or the grafting of polymer brushes, while several other strategies are also possible (see Table 2). SAMs are common due to their ease-of-use, however they suffer from limited long-term stability and are limited to metal (typically gold) or silica substrates [72]. A recent study showed significantly improved stability of ethylene glycol-based SAMs, showing resistance to cell adhesion (via adsorbed proteins) for up to 35 days [73].

Alternatively, polymer brushes can be either "grafted to" or "grafted from" polymer substrates: pre-formed polymer chains are "grafted to" substrates with a single step, whereas "grafting from" a substrate implies the polymerization of a monomer from a surface-bound initiator or chain transfer agent. In recent years, "grafting from" substrates using surface-initiated living radical polymerization techniques (in particular atom transfer radical polymerization (ATRP), but also reversible addition-fragmentation chain transfer (RAFT), nitroxide-mediated polymerization (NMP) and iniferter-based methods) have become far more popular, due to the possibility of obtaining high grafting densities and thick layers while retaining low polydispersity, and applicability to a large range of synthetic monomers [74-76]. "Grafting from" methods require an initiator or chain transfer agent (CTA) at the surface, from which polymerization is initiated; these can be incorporated into alkanethiols for use in SAMs [77], coated onto polymer substrates [78], or incorporated into polymers to create macroinitiators [79-81] and macroCTAs [82], which may potentially have broader applicability as cell substrates.

The exact mechanisms behind the ability of various substrates to reduce protein adsorption are not fully understood and are an area of active research [83,84]. Polymers and SAM layers that contain molecules which are polar, electrically neutral and contain hydrogen bond acceptor groups are generally required [85], although materials that have charge distributions within a small scale such as zwitterionic groups can effectively reduce non-specific protein adsorption. Hydrophilic materials are commonly used, as some models of protein adsorption cite the ability of certain materials to couple water "tightly" as the underlying mechanism of adsorption resistance. Other important properties include the density and packing of polymer chains, polymer brush structure, local osmotic effects and chain mobility $[59,77,86]$. It is possible that different mechanisms may be responsible for protein resistance associated with different polymers and polymer architectures.

It is important to note that "low-fouling" surfaces can vary in their ability to reduce protein adsorption; for example, star-PEG coatings allowed attached proteins to better retain their bioactivity compared to other coatings such as linear PEG or adsorbed bovine serum albumin (BSA) [55,56]. PEG-based polymers are also known to undergo oxidation (particularly in vivo or in biological fluids) which can impair their low-fouling performance $[64,87,88]$, while betaine-based zwitterionic polymers may 
Table 2

Surface coating techniques for creating low-fouling substrates that can be activated for ligand immobilization.

\begin{tabular}{|c|c|c|}
\hline Coating method & Notes & References \\
\hline Self-assembled monolayers (SAMs) & $\begin{array}{l}\text { Commonly used to test attachment chemistries and to create simple 2D } \\
\text { models for polymer substrates. Short chain PEG-thiols or PEG-silanes } \\
\text { self-assemble onto a gold or silica substrate (respectively). A wide variety of } \\
\text { functional molecules can be assembled into the monolayer for } \\
\text { functionalisation. Simple formation. Easy to change functional groups for later } \\
\text { ligand attachment. Cannot be used to functionalise polymers. Limited to 2D } \\
\text { substrates. Limited robustness and long-term stability. }\end{array}$ & {$[95-98]$} \\
\hline Polymer brushes ("grafting to") & $\begin{array}{l}\text { Polymer chains attached as preformed chains to a substrate. Excellent control } \\
\text { over chain length and brush thickness. Limited brush density, which can } \\
\text { increase non-specific interactions. }\end{array}$ & {$[56,70,99]$} \\
\hline Polymer brushes ("grafting from”) & $\begin{array}{l}\text { Polymer chains are polymerised from surfaces with appropriate functional } \\
\text { groups. Several preparation methods available, including ATRP, RAFT, NMP } \\
\text { and iniferter methods. Higher densities and better resistance to fouling than } \\
\text { coatings via the "grafting to" method. Uses synthetic monomers, and multiple } \\
\text { monomers can be co-grafted to create a functional brush surface. Low fouling } \\
\text { brushes can stay repellent for several weeks under some conditions. Thick } \\
\text { films still possible at higher brush density. }\end{array}$ & {$[74,75,95,100]$} \\
\hline $\begin{array}{l}\text { Interpenetrating polymer networks } \\
\text { (IPNs) }\end{array}$ & $\begin{array}{l}\text { Multiple monomers are polymerised into a single, intertwined network, each } \\
\text { monomer providing different functionality (e.g. modulus variation, } \\
\text { attachment of ligands, protein repellency). Independent control of modulus } \\
\text { and ligand display. }\end{array}$ & {$[26,101,102]$} \\
\hline Layer-by-layer (LbL) deposition & $\begin{array}{l}\text { Multiple coating layers are built up via electrostatic, hydrogen bonding or } \\
\text { covalent interactions. Both synthetic and natural polymers can be used in } \\
\text { various systems. }\end{array}$ & {$[67,68,103]$} \\
\hline Plasma polymers & $\begin{array}{l}\text { Uses plasma to generate a highly crosslinked thin film from a volatile } \\
\text { monomer. These monomers can contain functional groups useful in coupling } \\
\text { reactions. Generally used with synthetic polymers. Good control over } \\
\text { thickness. Applicable to a wide range of surfaces. Mechanisms and products } \\
\text { not fully understood and varied reactive groups can be present in the final } \\
\text { layer. }\end{array}$ & {$[85,104,105]$} \\
\hline Lipid bilayers & $\begin{array}{l}\text { Phospholipids self-assemble into a layer via hydrophilic/hydrophobic } \\
\text { interactions. Functionalisation via the inclusion of functional components in } \\
\text { the layer. }\end{array}$ & {$[106,107]$} \\
\hline
\end{tabular}

be more resistant to fouling, particularly in the long-term $[64,89]$. Several reviews are available that examine the use of both PEG and zwitterionic polymers as functionalizable, low-fouling substrates $[17,90,91]$.

It should be noted that no surface has yet been shown to completely resist protein adsorption, and proteins can still interact with low-fouling brushes (and presumably hydrogels and other substrates) through various mechanisms, including diffusion through brush layers and adsorption to the underlying surface (if the brush layer is not sufficiently dense), adsorption at the brush-solution interface and entanglement within the brush layer [92]. Hence it is important that substrates are thoroughly rinsed after ligand conjugation. It is also noteworthy that cell survival and development often requires more than growth factors (in solution or on a scaffold) [93] or cell adhesion molecules (CAMs) [94] alone. When investigating these factors and using low protein fouling substrates, it may be necessary to co-immobilize an integrin binding ligand or similar, as ECM molecules expressed by cells will not adsorb in large quantities onto low fouling materials.

\subsubsection{Mechanical properties of the substrate}

The mechanical properties of the underlying material have also been shown to be able to modulate cellular behavior including cell attachment and spreading $[108,109]$ migration [110,111] and differentiation $[102,108,109,112,113]$ in a broad range of cell types. The mechanisms by which cells sense (through receptor signaling) the mechanical properties of an underlying substrate/scaffold are biologically complex and an area of active research, and as such are partially outside the scope of this review; we refer the interested reader to the following reviews [114-117]. However, brief discussion of several key concepts related to material design is required.

Integrin receptors act as cellular mechanosensors; following the binding of the integrin receptor to an appropriate ligand, the actin cytoskeleton exerts tension on the receptor-ligand complex, and through these actin fibers, on the external environment. The tension through this connection causes proteins within the receptor to unfold and reveal hidden binding sites for proteins such as vinculin [114]. Vinculin in particular promotes the clustering of receptors (that are bound to ligands) into focal adhesion complexes, a vital intracellular structure in the cell adhesion process [114]. As such, if the external environment is not rigid enough, insufficient tension will be formed within the receptor for this process to occur; hence, integrin ligands on some (although not all) soft substrates have been shown to inhibit focal adhesion formation [109].

Several recent studies have thrown further light onto the mechanisms by which cells sense mechanical changes in the environment, and how controlling the mechanical properties of the substrate can influence receptor activation. Huebsch et al. examined ligand clustering related to variably stiff gels [118], while Trappmann et al. showed that the effects of changed modulus could also be replicated by attaching collagen at different crosslink densities 
at a constant modulus [109]. Keung et al. examined intracellular signaling, in particular the role of Rho GTPases, in response to substrates of varying modulus [119] while Grashoff et al. examined tension within vinculin structures in focal adhesions [120]. These studies, along with many others, allude to the need to treat the integrin-ligand complex as a dynamic object that can sense and respond to many stimuli, not simply the presence or absence of an appropriate ligand. Further studies are needed to examine how nanoscale mechanical interactions influence cell behavior, and how control of these interactions can be built into cell-instructive scaffolds.

\subsection{Biofunctionality conclusions}

Ligand-receptor interactions are not simple on-off switches; they are complex signaling systems that can respond to a range of stimuli. Choosing an appropriate ligand with high specificity and affinity for a given receptor allows greater control over downstream signals and more straightforward or more detailed analysis of resulting cell behavior. Attaching ligands to a surface can modulate responses in several ways. Changes in the conformation or accessibility of the binding site will affect binding. Further activation of the receptor's signaling pathways can then also be affected by factors that are specific to each receptor, including mechanical properties of the substrate, requirements that the ligand be internalized for normal signaling, or interactions of signaling pathways with other proteins that are co-presented.

Surface-attached ligands are only one part of the entire cell environment, and both their ability to activate receptors and the effects of receptor activation are modulated by other components of that environment [121-123].

\section{Presentation of ligands}

A large range of techniques exists for presenting or modifying substrates with protein- or peptide-based ligands (see Table 3). These substrates can include 2D polymer surfaces, hydrogels, or 3D-architectured materials like electrospun fibers, foams or sponges. Both synthetic and naturally occurring materials may be modified using an appropriate scheme. Several reviews have examined chemical strategies for immobilizing proteins and peptides onto a surface, however these either focus on other areas of study such as nanoparticles [124] or protein biochips [125], or focus on different ligands that may be immobilized [1]. Activating receptors using ligand-modified substrates has additional complications that may not be as important in these other areas, but which are critical in cell-material interactions. These are discussed in Sections 2 and 4.

\subsection{Protein and peptide hydrogels}

Using protein- and peptide-based hydrogels as 3D cellular scaffolds provides a conceptually simple way to present receptor-binding motifs without any chemical modification. Matrigel is a complex mix of proteins purified from mouse sarcoma tissue, which has been successfully used as a cell culture substrate. It is composed of a mixture of laminin, collagen and entactin, along with a large number of other components. While this complexity may enable it to support cells effectively, its composition is poorly known and may vary from batch to batch, making deeper analysis difficult [126]. Other protein mixtures are also available that have similar complexity [127]. Gels made from purified ECM proteins such as collagen, fibronectin, laminin and vitronectin are also popular, and combinations of these proteins have been used to investigate the effects of different compositions on cell behavior [128,129].

Several different types of self-assembling peptide (SAP) are in common use as cellular scaffolds, and this area of study has been reviewed [130,131]. SAPs can also incorporate different signals, including RGD [132-134], other adhesion motifs [14,135] and growth factor mimicking sequences $[16,136,137]$. Sequences that bind heparin or bind growth factors directly have also been included into SAPs, and this is discussed briefly in Section 3.2.2. Peptide signaling motifs can also be incorporated into modular protein gel materials $[138,139]$. These materials are recombinantly produced proteins designed to contain multiple short peptide sequences that can control mechanical properties, degradation and growth factor sequestration as well as presenting receptor-binding sequences.

Both modular protein and SAP gels can also be designed to gel in vivo after implantation in liquid form, allowing the gel to mold itself to fit within a lesion prior to gelation, which may be of use in future applications. Gelation occurs via reversible shear thinning or in response to

Table 3

An overview of methods that are discussed within this review for presenting receptor ligands (typically amino acid-based, although not in all cases) from various substrates.

\begin{tabular}{|c|c|c|}
\hline $\begin{array}{l}\text { Expression within a poly/oligopeptide substrate } \\
\text { - ECM protein gels } \\
\text { - Self-assembling peptide gels } \\
\text { - Modular protein gels }\end{array}$ & $\begin{array}{l}\text { Adsorption } \\
\text { - Physisorption of e.g. proteins } \\
\text { - Advanced methods such as } \\
\text { chemisorption of DOPA }\end{array}$ & $\begin{array}{l}\text { Affinity interactions } \\
\text { - Growth factor affinity } \\
\text { binding to ECM proteins } \\
\text { - Biotin/avidin binding } \\
\text { - His6/Ni }{ }^{2+} \text {-NTA } \\
\text { - Protein pairs } \\
\text { - Protein-binding peptide } \\
\text { sequences (extracted } \\
\text { from growth factors) } \\
\text { - Peptide sequences } \\
\text { (discovered via phage } \\
\text { display) } \\
\text { - Lectin-mediated binding }\end{array}$ \\
\hline
\end{tabular}

Covalent attachment

- Unmodified ligands

via amines (lysine or

N-terminus)

via carboxylic acids

(glutamic/aspartic acids or

C-terminus)

via thiols (cysteine)

via other groups

- Modified ligands

Click reactions

Other advanced reactions

- UV-active functional groups 
environmental stimuli such as temperature or ionic strength [131,140]. Compared to ECM protein gels, they provide the researcher with control over the signals being presented to cells, as they are far better defined than complex protein mixes, and are more likely candidates for therapeutic uses. While protein mixes are likely to remain the standard for some time for cell culture, due to strong cell interactions and ease of use, engineered peptide and protein gels are likely to provide a way forward for well-controlled stimulation of cell behavior.

\subsection{Conjugation of unmodified ligands}

\subsubsection{Non-specific adsorption}

Pretreatment of surfaces by passive adsorption has been used in many studies to activate surfaces with ECM proteins. This is a fast, simple technique that requires no knowledge of chemistry, and can be adapted to produce microarrays of a large number of spots, which can be used for combinatorial studies of ECM proteins and their interactions with cells [141]. It is without doubt the easiest technique available to modify substrates.

However using adsorption as a modification technique has several disadvantages. Most importantly, proteins attached via adsorption will change conformation due to their interaction with the surface, affecting biofunctionality. The orientation of adsorbed proteins and their active domains also cannot be controlled, and furthermore, any proteins present in cell culture media or in the in vivo environment may also adsorb onto a permissive surface, while at the same time, proteins of interest may desorb. This leads to a situation where the types of ligands, their density and the arrangement and biofunctionality of their binding sites are all unknown, giving a very poorly defined culture environment. For example, Garcia and coworkers have investigated the adsorption of fibronectin and fibronectin domains on surfaces presenting different functional groups, and showed that adsorption and later cell response was modulated by the changing surface $[39,40,142]$. Kohen et al. also showed changes in the structure of Matrigel after adsorption on various surfaces, which were related to subsequent changes in cellular response [41].

More advanced adsorption methods that attempt to address some of these concerns do exist [70]. For example, Messersmith and coworkers use adsorbed L-DOPA (L-3,4dihydroxyphenylalanine) materials to modify surfaces for subsequent attachment of biomolecules [143,144]. L-DOPA adsorbs strongly to virtually any surface and is stable over long periods of time $[78,145]$, making this method broadly applicable and stemming concerns about desorption.

Furthermore, recent work has shown that an appropriate choice of surface chemistry, followed by adsorption of ECM proteins, can provide an excellent substrate for longterm stem cell culture $[146,147]$, demonstrating that an advanced level of control may not be required in some applications.

\subsubsection{Affinity interactions}

Many growth factors (GFs) and other cell-stimulatory molecules contain short peptide sequences that will reversibly bind to ECM proteins, proteoglycans or glycosaminoglycans (GAGs). These functional sequences include heparin-, collagen- and fibronectin-binding domains, and provide a further non-covalent method by which ligands may be attached. These binding sequences can also be incorporated into fusion peptides or recombinant proteins alongside other ligands; we review this area separately within Section 3.3.3. These areas have been reviewed $[148,149]$ and so only a brief overview and other related work will be presented here. A different affinitybased strategy which binds ECM proteins via lectinmediated interactions, is discussed briefly in Section 4.4.3.

Heparin, a negatively charged GAG, is a particularly popular substrate for GF-sequestration, and can be incorporated into biomaterials both covalently and noncovalently [150]. Covalent methods use various reactions: for example, unmodified heparin may be crosslinked using carbodiimide chemistry [151,152], or modified to contain various functional groups [152-154]. Noncovalent methods have been developed that first covalently attach peptide sequences such as KRTGQYKL [155,156], TYRSRKY [157], FHRRIKA [25,158] or others [158-160] that are derived from heparin-binding domains in fibroblast growth factor (FGF) or other proteins. Heparin, and in turn growth factors, can then be sequestered from the extracellular environment, or can be bound prior to cell seeding/implantation for sustained release. A visual summary of various methods for functionalizing substrates with basic FGF (bFGF, the most commonly used GF in these studies) is shown in Fig. 2, encompassing studies on a wide range of synthetic polymer and peptide-based substrates. Heparin-binding peptide sequences can also be introduced into self-assembling peptides [161] and used to deliver growth factors [162]. In an interesting approach, Anderson et al. first immobilized heparin molecules that had been modified with photoreactive azides [52]. They then used the growth factor binding capabilities of heparin to orient VEGF in a presumably highly bioactive orientation, followed by ultraviolet (UV) irradiation to covalently "lock" the signal in place.

Growth factor binding domains can also be found on many ECM proteins [2,148], including collagen (for FGF) [163] and fibronectin (for VEGF) [164]. Using these mechanisms for GF sequestration may allow more specificity, as heparin binding domains are found in many different GFs. Further research is needed to examine how these GFmatrix interactions affect bioactivity and whether they can be used for engineering cell substrates.

Other smaller molecules have also been used to replace heparin. Lin and Anseth used the KRTGQYKL peptide sequence (discussed above) to directly sequester FGF, without the use of heparin as an intermediary [165]. Other sequences have been shown to sequester transforming growth factor beta (TGF- $\beta$ ) [166], while sequences that bind a growth factor directly have been included into self-assembling peptides [167]. Other groups investigated sulfonated peptides that were capable of mimicking the growth factor binding properties of heparin [168,169], and Maynard and coworkers later investigated substrates that use poly(styrene sulfonate)-based copolymers as a similar mimic $[170,171]$. 


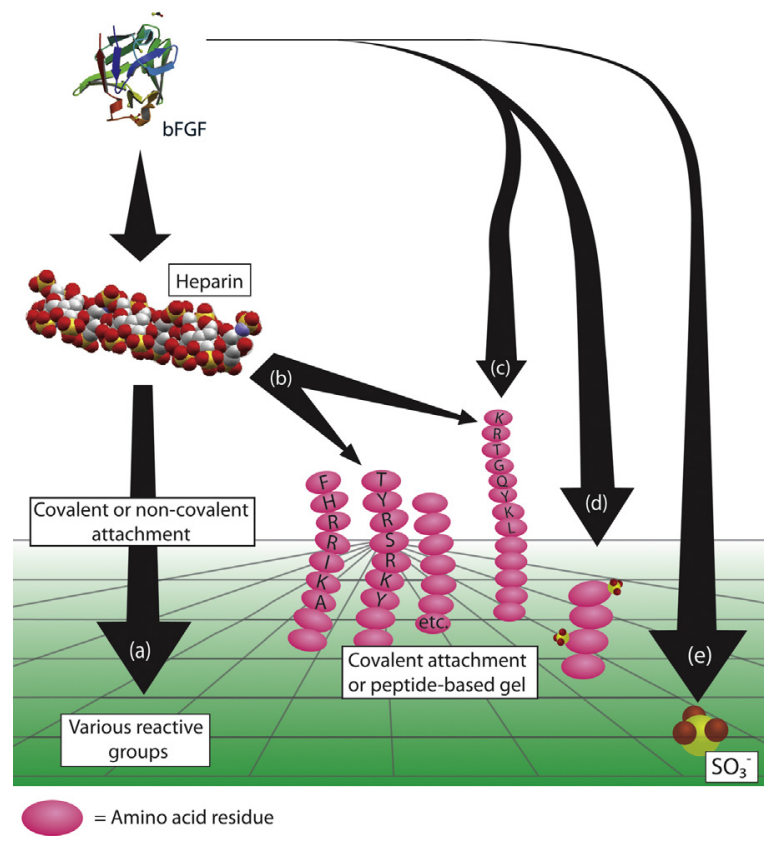

Fig. 2. Strategies for affinity-based attachment of bFGF, a common heparin-binding growth factor. Heparin can be conjugated to a substrate covalently or via non-covalent methods such as electrostatic attraction, (a). Substrates can also be modified via affinity interactions with short peptides, (b). Heparin binding growth factors such as bFGF can also interact directly with peptides such as the KRTGQYKL sequence, (c), sulfonated peptides, (d), or with sulfonated synthetic polymers (e).

Structures for bFGF and heparin adapted from the Protein Data Bank (reference codes $1 \mathrm{HPN}$ and $4 \mathrm{FGF}$ ).

Using these methods, which mimic the mechanisms by which many growth factors are presented in vivo, has many advantages. Presentation of growth factors via ECM affinity interactions prevents any loss of activity and specificity, and can even modulate or enhance certain interactions $[148,172]$. Furthermore, no chemical modifications or mutations of the proteins are required. Sequestration also allows growth factors to be passively released over time [148], which may be an advantage over covalent binding in cases where internalization of the growth factor can be an important part of signaling, or when a timed release of growth factor is desired. Some of these systems, for example those involving heparin, also have the potential to interact with other growth factors, such as those released by cells. This could be either advantageous or disadvantageous, but needs to be kept in mind when designing studies.

\subsubsection{Covalent attachment of ligands via amines or carboxyls}

Amines are by far the most common target for covalent attachment of proteins, being found in lysine residues (one of the most common amino acids) as well as at the $\mathrm{N}$-terminus. The high abundance of available, surfaceexposed amine functional groups means that almost any protein may be covalently bound to substrates in this way without further modification via a range of different chemistries (Fig. 3). However, this method can also lead to poor site specificity, poor control over orientation and/or multiple point conjugation, which can reduce biofunctionality in an unquantifiable way [5,37,173]. Some linker protocols may also risk the ligand self-crosslinking. The traditional coupling agents for amine conjugation are well known [174] and will not be reviewed here. Those in most common use include EDC/NHS ( $N$-(3-dimethylaminopropyl)- $N^{\prime}$-ethylcarbodiimide with $N$-hydroxysuccinimide activation), CDI (1,1'carbonyldiimidazole)and SANPAH ( $N$-sulfosuccinimidyl6-(4'-azido-2'-nitrophenyl-amino) hexanoate). Many of these reagents are water sensitive, which can drastically lower yields, although evaporating the ligand solution during conjugation can be used to improve yields [67].

Coupling via acidic residues or via the C-terminus suffers from many of the same drawbacks. It is more rarely used, but a small number of studies have immobilized ligands to amine-presenting substrates and shown increased bioactivity compared to unmodified scaffolds [11,175,176].

However, in some circumstances, attachment via amines may be effective. In the case where a ligand contains no lysine residues (e.g., murine epidermal growth factor $[37,46])$, these methods may be simple yet effective. N-terminal specific reactions are available, which may alleviate many of the problems with amine-targeting strategies. However, many of these require specific amino acid residues at the terminus and are yet to be used to conjugate ligands to surfaces to create defined culture environments. One generally applicable protocol uses the altered $\mathrm{p} K_{\mathrm{a}}$ of the terminal amine compared with those in lysine side-chains, performing the conjugation in an appropriate $\mathrm{pH}$ buffer to ensure that only the terminal amine is protonated. However, targeting of the N-terminal amine using this method is not perfect and $\varepsilon$-amines are likely to be modified as well [177]. One study describes a method for linking RGD peptides with $\mathrm{N}$-terminal cysteines (at the free amine) via a phenoxy amino squarate reactive group, even in the presence of other free cysteines [178], while several other potentially useful techniques for targeting the $\mathrm{N}$-terminus have been reviewed $[179,180]$.

\subsubsection{Covalent attachment via thiols}

Thiols are a reactive group found on cysteine residues. Cysteine is a rare amino acid, and so unlike amines and carboxyls, most proteins contain few thiols, lessening problems related to a lack of site specificity [124,180]. Reactions with thiols are also specific and efficient in many cases.

However, the use of thiol reactions has a separate set of complications. For example, disulfide bonds between cysteine residues can be formed, which are often a key element in defining protein structure $[173,180]$. Also, they are commonly found within receptor binding sites and other active sites, and so conjugation in or near these domains may reduce biofunctionality. Finally, due to the aforementioned rarity of cysteine residues in many proteins, thiols may not be present in some proteins of interest. While this precludes the attachment of unmodified proteins, it is useful in strategies that introduce thiols specifically for conjugation (see Section 3.3.1).

A summary of reactions that have been used to conjugate peptide-based ligands via the thiol functional groups on cysteines is presented in Fig. 4. The most commonly 


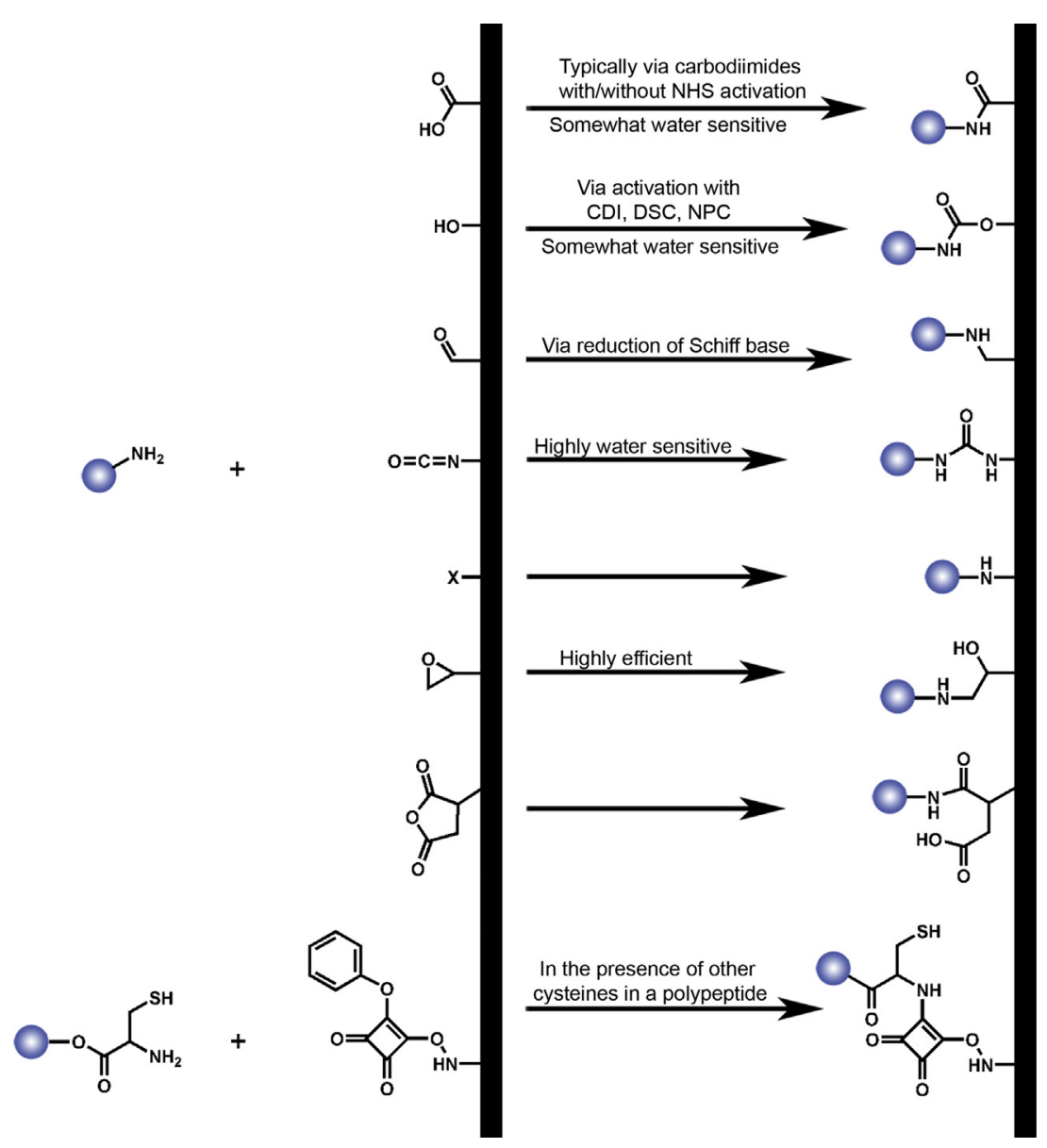

Fig. 3. Amine-targeting reactions for ligand attachment (blue sphere represents the ligand being attached). From top to bottom: reaction with carboxylic acid (typically via carbodiimides such as EDC) to form an amide bond; with a hydroxyl (via various crosslinking reagents) to form a carbamate; with an aldehyde (2 step via reduction of a Schiff base); with an isocyanate to form a carbamide; with a halogen (via nucleophilic substitution); with an epoxide; with an anhydride; and reaction of the amine in N-terminal cysteines with phenoxy amino squarate. (For interpretation of the references to color in this figure legend, the reader is referred to the web version of the article.)

used reactions are Michael-type addition reactions with alkene-containing reactive groups such as maleimides, acryloyls and vinyl sulfones [181]. Maleimides are the most commonly used for immobilizing ligands to surfaces, either directly or to surface amines via a succinimidyl-4( $N$-maleimidomethyl)cyclohexane-1-carboxylate (SMCC) spacer $[26,49,182,183]$. Thiol-ene photocoupling (a separate reaction also involving thiol groups reacting at carbon-carbon double bonds) has also become popular for spatially controlled immobilization of ligands [71,184]. Thiols also form permanent (debatably covalent) bonds with some metals, such as gold, which can be used to conjugate ligands onto gold nanoparticles within polymer matrices (see Section 4.1.3 for detail on this particular technique and its application). Another potentially useful chemistry is the use of a 2-pyridyldithiol-based crosslinker to form a disulfide bond $[13,103]$. Haloacetyl groups can also be used to bind thiols; although a range of crosslinkers is available [174], this reaction is only rarely used in this application [185].

Under certain conditions, conjugation via thiols may be a very good method for attaching ligands, in particular when a single thiol can be targeted that does not play any known biological role.

\subsubsection{Covalent attachment via other groups}

Other techniques do exist which allow covalent coupling to other reactive groups, on amino acids such as tyrosine, arginine, methionine and phenylalanine $[173,180,188]$. These could also be used for surface functionalization. A recent study used tyrosine-tyrosine photocoupling with visible light to attach an RGD peptide to a resilin-based protein substrate [189].

\subsection{Advanced conjugation with modified ligands}

\subsubsection{Introducing reactive groups}

In recent years, many studies have examined chemical modifications of ligands that allow more advanced conjugation techniques. Short peptides and synthetic ligands can generally be manufactured to include almost any desired reactive group without major difficulty; however, proteins are more difficult to modify. Studies have used bifunctional linkers to modify free amines on the 


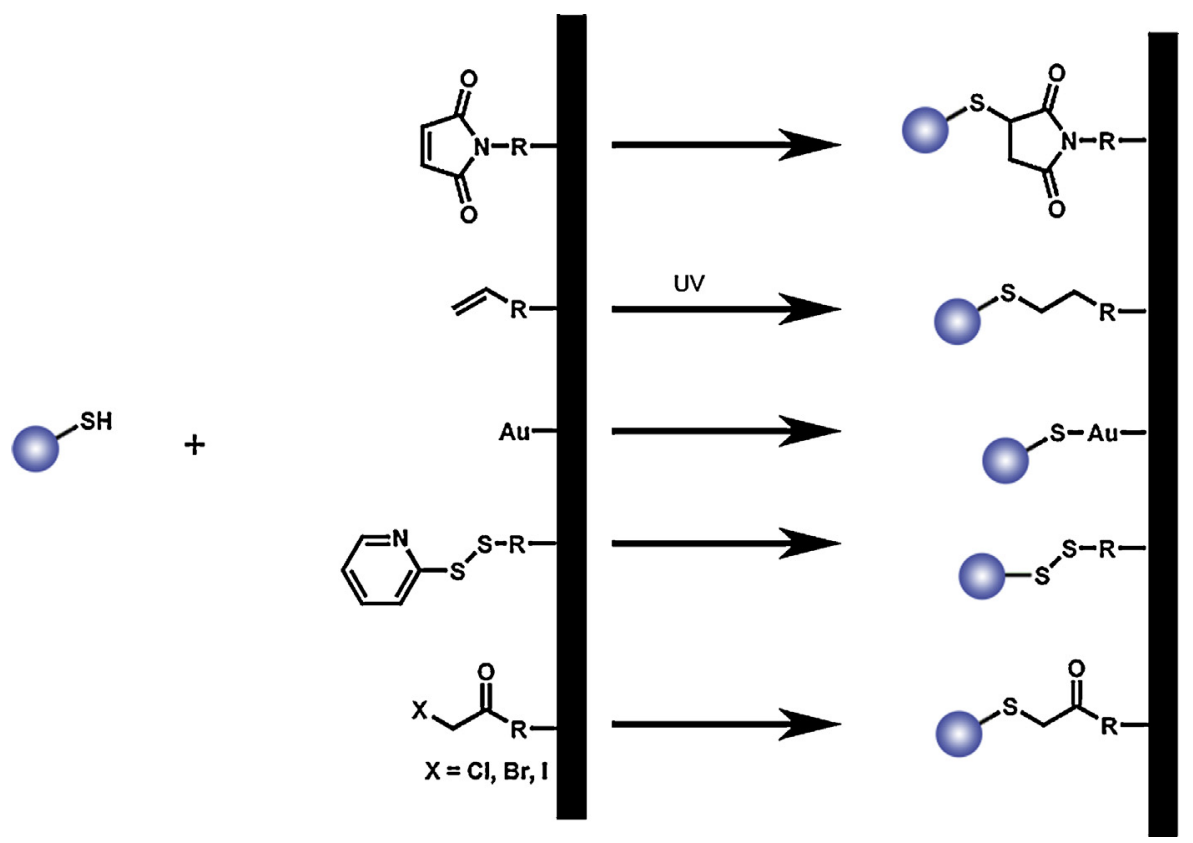

Fig. 4. Thiol-targeting reactions for ligand attachment (blue sphere represents the ligand being attached). From top to bottom: Michael-type addition to a maleimide; thiol-ene photoclick reaction; reaction with gold surface or nanoparticle; reaction with 2-pyridyldithiol crosslinker; reaction with haloacetyl. Note that the Michael-type addition reaction can also be performed using vinyl sulfone or acrylate reactive groups, and that other thiol-based reactions are also available $[186,187]$. (For interpretation of the references to color in this figure legend, the reader is referred to the web version of the article.)

protein, for example using SANPAH to create photoreactive ligands $[69,190]$. However, these approaches can also suffer from the same lack of site-specificity and changes in conformation as those techniques outlined in Section 3.2.

More recent work has created proteins with reactive groups at single, well-defined locations (often the $\mathrm{N}$ - or C-termini) via a range of methods. In the simplest case, extra cysteine residues may be added to the termini of proteins [191-193] for conjugation using chemistries from Section 3.2.4. In the case where there is only a single available cysteine at a terminus, this allows for control over orientation and prevents possible changes to bioactivity. As previously mentioned in Section 3.2.3, reactions that specifically target $\mathrm{N}$-terminal cysteines are also available.

In recent times, a new range of reactions has become popular for conjugation of ligands to surfaces. These involve the use of "bio-orthogonal" reactive groups; groups that do not undergo notable side reactions with amines, thiols, carboxyls and other groups that are commonly present in a biological milieu [194]. These include groups such as azides, aryl azides, acetylenes, aldehydes and dienes, as well as chemical motifs such as biotin, which can be introduced site-specifically into proteins via a variety of techniques. These techniques have been well reviewed and include enzymatic reactions, site-specific ligation reactions, and the inclusion of non-canonical amino acids during protein expression [173,194-196]. Examples of the incorporation of specific functional groups into proteins (for surface attachment) will be discussed throughout this section, but are summarized in Table 4 .

\subsubsection{Advanced covalent coupling}

The range of "click" chemistry reactions is of particular interest for attaching ligands [212]. The term "click" incorporates a family of reactions that display particular properties, including high specificity, stable linkages with orientation control and high yield under mild conditions (for ligand conjugation, ideally in aqueous solutions), many of which make them highly useful in materials design $[213,214]$. These properties align well with those desired in a ligand conjugation reaction, and many of the reactive groups used have some degree of bio-orthogonality. The group of reactions belonging to the click family is loosely defined, but includes thiol-ene click reactions (see Section 3.2.4), copper-mediated and copper-free (strain promoted) azide-alkyne cycloadditions, and Diels-Alder reactions. Many "ligation" reactions also share several of these properties and are sometimes included within the "click" family, and oxime ligations in particular have been used for conjugation of proteins and peptides to surfaces. These reactions require the introduction of functional groups not naturally found in protein or peptide ligands, with the exception of some ligation reactions and thiol-based reactions (although these may benefit from an introduced thiol, as discussed above). While this requires extra effort to introduce the groups, it gives the researcher full control over the site of conjugation. A range of different bio-orthogonal chemistries is discussed below, and summarized within Fig. 5.

The copper-mediated azide-alkyne click (CuAAC) reaction is the most well known of these. Studies have used both azide [215] and alkyne [157,216] functionalities to attach peptide ligands to a surface with the corresponding 
Table 4

Modification of proteins to site-specifically include extra functional groups for surface conjugation. Modification of peptides is not included as it is presumed these can be incorporated during synthesis. Use of heterobifunctional linkers that were not site specific (i.e. using NHS esters, maleimides or similar) is also not included. See review by de Graaf et al. for further examples of the incorporation of non-canonical amino acids [173].

\begin{tabular}{|c|c|c|}
\hline Reactive group introduced & Comments & Reference \\
\hline \multirow[t]{2}{*}{ Aldehyde } & $\begin{array}{l}\text { Enzymatic modification using } \\
\text { formylglycine-generating enzyme. Requires an } \\
\text { acceptor sequence within the protein }\end{array}$ & {$[197]$} \\
\hline & $\begin{array}{l}\text { Chemical modification of N-terminal amine } \\
\text { using pyridoxal-5-phosphate }\end{array}$ & {$[198]$} \\
\hline Aldehyde/ketone & Incorporation of a non-canonical, amino acid & [173] \\
\hline \multirow[t]{2}{*}{ Azide } & $\begin{array}{l}\text { Enzymatic modification using protein farnesyl } \\
\text { transferase. Requires an acceptor sequence } \\
\text { within the protein }\end{array}$ & [199] \\
\hline & Incorporation of a non-canonical, amino acid & [200] \\
\hline Acetylene & Incorporation of non-canonical amino acids & [173] \\
\hline Biotin & $\begin{array}{l}\text { Enzymatic modification using biotin ligase. } \\
\text { Requires an acceptor sequence within the } \\
\text { protein }\end{array}$ & {$[201]$} \\
\hline Aryl azide & Incorporation of nan-canonical amino acid & {$[202-204]$} \\
\hline Diene & $\begin{array}{l}\text { Heterobifunctional linker via expressed } \\
\text { protein ligation (C-terminal specific) }\end{array}$ & [205] \\
\hline $\begin{array}{l}\text { Protein or peptide binding motifs } \\
\text { (including hexahistidine tags, } \\
\text { ECM-binding domains, } \\
\text { polymer-binding sequences, etc.) }\end{array}$ & $\begin{array}{l}\text { Creation of a fusion protein containing the } \\
\text { signaling protein along with binding motif }\end{array}$ & {$[38,206-211]$} \\
\hline
\end{tabular}

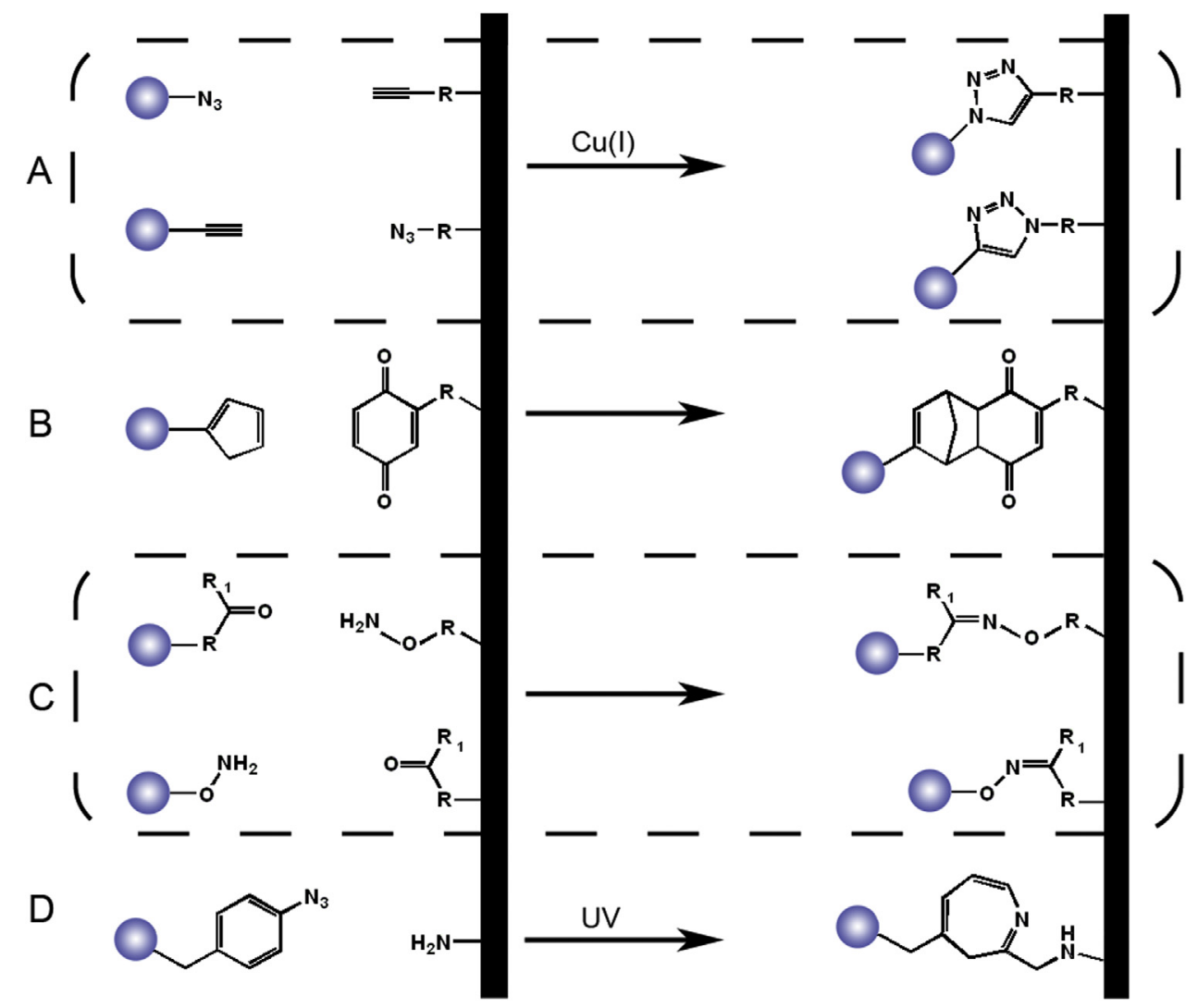

Fig. 5. Bio-orthogonal chemistries for covalent ligand immobilisation. Dotted lines surround examples where the same reaction is used, but with the location of reactive groups reversed. (A) Copper mediated azide-alkyne click. Copper (I) is typically generated from copper (II) using a reducing agent such as sodium ascorbate. (B) Diels-Alder reaction. (C) Oxime ligation. (D) Photocoupling using an aryl azide. The most likely reaction pathway of several available is shown, which involves ring expansion followed by reaction with an amine or other nucleophile. However, other reactions also occur which do not require a nucleophile to be present or do not involve ring expansion. 
functional group. Proteins have also been attached to surfaces via click-chemistry. Duckworth et al. used the enzyme protein farnesyl transferase to add an azide group to a protein for conjugation to a surface via CuAAC [199]. The protein was engineered to bear a four amino acid enzyme recognition sequence at the C-terminus. Sun et al. also reported the surface conjugation of an azide-functional protein which incorporated an azide-carrying methionine at the terminus [200].

The reaction requires copper as a catalyst, which might interact with some proteins in an unwanted fashion during the reaction, and may be cytotoxic even at low concentrations. Previous studies have found that copper can be removed with high efficiency using complexation with a chelating agent such as EDTA (ethylenediaminetetraacetic acid) [217], although complete removal from a surface is difficult to verify. Despite the reaction nominally proceeding to high yields, most studies so far have used large excesses of ligand. The reaction can be slow, although this can be improved by the use of a copper ligand such as tris((1-benzyl-1H-1,2,3-triazol-4-yl)methyl)amine (TBTA) [218]. Strain induced azide alkyne click reactions have not been used for attaching receptor ligands as yet, although cyclooctyne functional peptides were used as a crosslinker in a hydrogel which also contained cells [219], illustrating that there were no apparent cytotoxicity issues associated with the reaction.

Diels-Alder reactions involve the conjugation of a diene to a dienophile [220]. These reactions are generally slower than other click reactions, but do not require any catalyst. The reaction is almost bio-orthogonal, however if using maleimides as the dienophile, care is needed due to potential cross-reactivity with cysteine [180]. Otherwise, the reaction is able to be performed in the presence of many other reactive groups, so, for example, Diels-Alder and $\mathrm{CuAAC}$ reactions can be used to co-immobilize two different ligands [221]. de Araújo et al. used expressed protein ligation to functionalize a protein with a diene reactive group. This protein could then be conjugated to a surface using surface maleimides as the dienophiles [205]. Mrksich, Yousaf and coworkers have published several studies examining the effect of adhesion peptides immobilized via Diels-Alder reactions, where hydroquinone groups on the substrate were oxidized (electrochemically or via photoactivation) to benzoquinones, which could then be targeted using a diene-functionalized ligand [222-224].

Quinone-activated substrates were also used in later studies for the attachment of oxyamine functional ligands using oxime ligation [225-229]. This reaction between a ketone/aldehyde and an oxyamine results in a stable bond and is not sensitive to aqueous reaction conditions. Oxime ligation was also used by Pauloehrl et al. for patterning of an RGD peptide, where a photocleavable group revealed an aldehyde upon deprotection [230].

The reaction has also been performed with the location of functional groups reversed, by modifying ligands with either ketone or aldehyde groups and conjugating to an oxyamine functionalized substrate. While there is potential for cross-reactivity with amines, in general the oxime reaction is heavily favored [194]. Maynard and coworkers have used this chemistry to immobilize a ketone-functionalized RGD peptide [171]. Bertozzi and coworkers describe a method to introduce aldehydes at either terminus of a protein, using enzymatic conversion of a cysteine into formylglycine within a 6-residue sequence $[197,231]$. Gilmore et al. describe an alternative method to convert an $\mathrm{N}$-terminal amine into an aldehyde using pyridoxal-5-phosphate [198]. This was later used to immobilize model proteins to substrates [232,233].

UV-mediated immobilization has been widely used in patterning studies, as detailed in Section 4.1.2. Aryl azides have also been introduced directly and site-specifically into proteins by incorporating p-azido phenylalanine, a noncanonical amino acid, into the protein sequence [204]. Carrico et al. immobilized a cellular adhesion protein of this type [202], while Ogiwara et al. immobilized a modified epidermal growth factor [203]. The "bind and lock" method of Anderson et al. (also see Section 3.2.2) is also of interest due to its ability to orient heparin-binding ligands prior to UV immobilization, as claimed by the authors [52]. UVmediated reactions between acrylates have also been used to immobilize multiple ligands within a three-dimensional hydrogel [234].

Other chemospecific reactions such as Staudinger, tetrazine and hydrazone and native chemical ligations have also been used for protein conjugation, although not for the generation of ligand-functionalized substrates applied to cell culture [124]. Several other bio-orthogonal reactions are also promising for these applications [194,235].

\subsubsection{Affinity interactions with modified ligands}

The interaction between biotin and members of the avidin family of proteins produces the strongest known non-covalent bond (dissociation constant $10^{-15}$ for avidin) [125]. This interaction has several advantages for immobilizing ligands: biotin is a small molecule and considered unlikely to interfere with bioactivity when attached to a ligand, the interaction occurs under mild conditions, and if a single biotin is added, consistent orientation of the ligand can be achieved [125]. Attachment via biotin-avidin interactions can also allow much higher yields and resulting bioactivity compared to a similar conjugation using EDC/NHS chemistry [201].

Biotin-avidin interactions have been used in many studies to immobilize ligands to a surface $[22,201,236-238]$. Biotinylating the ligand can be done pre-translation for recombinant proteins [22], post-translation using bifunctional linkers [174], or in a site-specific manner using biotin ligase [201]. This interaction is compatible with and orthogonal to many other conjugation reactions [239].

Substrates are typically activated with avidin or derivatives such as streptavidin and NeutrAvidin ${ }^{\mathrm{TM}}$ prior to conjugation. These vary in several relevant properties including production method, cost and non-specific binding. Recent work showed that both use of NeutrAvidin and extra blocking may be required to reduce non-specific adsorption of proteins [240]. Surfaces are activated with avidins by adsorption or amine-targeting covalent linkages, as these methods are simple and can still allow effective biotin-avidin binding. Advanced conjugation methods are not generally used, although the method used for 
avidin activation has been shown to affect subsequent biotin binding [99]. Alternatively, the substrate may also be biotin-activated, taking advantage of the avidins' ability to bind up to four biotins (making the final linkage biotin-streptavidin-biotin) [56,238].

Similarly, pairs of proteins which exhibit high-affinity, non-covalent binding such as human serum albumin/albumin binding domain [210] and barnase/barstar [211] were used by Wylie et al. to prepare substrates with attached proteins. The second study from this group showed that it was possible to accurately pattern multiple factors using different binding pairs (biotin/streptavidin and barnase/barstar), as the interactions of the different binding pairs are highly specific and mutually orthogonal [211], while further studies from the same group examined binding pairs with lower affinities for slow release studies (see Section 4.4.1).

Hexahistidine (His6) motifs are commonly used in the purification of recombinant proteins, but can also be used to bind proteins onto cell culture substrates. Typically a surface activated with nickel-nitriloacetic acid (Ni-NTA) is used [37,241,242], although one study used zinc due to concerns with the potential cytotoxicity of nickel [206]. Dissociation constants down to $10^{-13}$ have been reported [124]. Binding is easily reversed using a divalent metal ion, chelating solution or a molecule that can bind competitively to the NTA complex [125]. This method has been reported to give control over orientation of the ligand being attached [124] and can increase bioactivity compared to covalent immobilization via amines [37]. Other affinity tags may also be used to immobilize proteins $[125,243]$.

As discussed in Section 3.2.2, certain amino acid sequences that are present in growth factors will bind to substrates in vivo such as ECM glycoproteins and GAGs. These sequences can also be adapted and used as ligands, so that, for example, a collagen-binding sequence may be included in a non-collagen-binding ligand for the purposes of attachment [208,244,245]. These types of peptide sequences were also reviewed by Hudalla and Murphy [148]. These generally have much weaker binding constants than those for either biotin-streptavidin or His6-Ni-NTA methods $\left(10^{-7}\right.$ to $\left.10^{-8}\right)$ [201] and so may undergo a slow release. Unlike sequestration of unmodified ligands, it is unknown whether these systems show any enhancement of bioactivity from oriented presentation. Proteins including epidermal growth factor (EGF) have also been captured via coiled-coil interactions, using proteins that have first been modified to contain a coil domain. This method will also allow for control of orientation, depending on where the coil sequence is placed $[38,204]$.

Peptide sequences have also been discovered that bind to synthetic polymer substrates such as polystyrene [209,246,247], poly(glycolic acid) [248] and polypyrrole [249]. These are discovered by phage display techniques that scan large libraries of peptide sequences for binding. A polystyrene-binding sequence had sufficient affinity for the surfaces that RGD patterns could mediate cell attachment for up to 1 week [246]. At this point most studies have examined adhesion peptide sequences, with the exception of Konagaya et al., who attached a polystyrene-binding sequence to EGF and examined cell response on the modified polystyrene [209].

\subsection{Presentation methods summary and conclusions}

A range of techniques that have been used to attach ligands to polymer substrates is presented in Table 5. Ultimately, the great advantage of using surface-bound ligands is the specificity of their interactions with proteins and cell surface receptors. The method chosen to present a ligand can have notable effects on the activity of the ligand, e.g., on the strength and specificity of the interaction, as well as surface density. Control over ligand presentation is thus the ultimate goal of any immobilization method. An ideal ligand-binding protocol should attach ligands with reliable yield, with all ligands in an identical conformation and orientation, limiting variation in biofunctionality. The effects of permanent versus impermanent attachment (see Section 2.2) should be taken into account. Ideally, the reaction would also have relatively fast kinetics, be high yielding and work consistently in aqueous buffers.

As such, many traditional methods of attaching (particularly protein) ligands, which can result in ligands being presented in ill-defined or random conformations, are far from ideal. Methods that use more specific chemistries can require more effort and in some cases are still not routine. However, attachment through a single, well-defined linkage, using chemistry with few competing side-reactions, should allow much better control over biofunctionality than some older methods in the literature, and orthogonal chemistries may also allow for the independent attachment of multiple factors.

The advantages of permanent or impermanent immobilization are dependent on many variables, and particularly in the case of growth factors, are still under investigation. For permanent immobilization, older non-specific techniques lack control over the final orientation and conformation of the ligands being immobilized. Techniques using click-type reactions, or quasi-permanent attachment using high affinity non-covalent interactions can overcome some of these issues. Affinity interactions such as growth factor sequestration or lectin-mediated binding, which mimic interactions that occur in vivo, are also of particular interest for the creation of dynamic substrates.

\section{Spatial and temporal control of ligand presentation}

Spatial patterning of receptor ligands is known to affect cell behavior [274,275]. Clustering of adhesion ligands is important in the formation of focal adhesions [118], and patterning of ligands into clusters (while keeping constant overall density) has been shown to have a greater influence over certain cellular behavior than changing overall density [267]. Gradients in the concentration of either growth factors or adhesion ligands can encourage cells to migrate, polarize or send processes toward areas of higher ligand density [276,277]. 
Table 5

Overview of ligand conjugation chemistries.

\begin{tabular}{|c|c|c|c|}
\hline Ligand reactive group & $\begin{array}{l}\text { Surface reactive group } \\
\text { (linker/catalyst/reaction type) }\end{array}$ & Notes & $\begin{array}{l}\text { References (see also } \\
\text { in-text) }\end{array}$ \\
\hline \multirow[t]{9}{*}{ Amine } & $\begin{array}{l}\text { Carboxylic acid (via } \\
\text { carbodiimides, e.g. } \\
\text { EDC } \pm \text { sulfo-NHS) }\end{array}$ & $\begin{array}{l}\text { Very commonly used reaction. Reagents sensitive to hydrolysis, but reaction can still be performed in aqueous solution. } \\
\text { Has been shown in several studies to be detrimental to bioactivity of ligands. }\end{array}$ & {$[37,67,104]$} \\
\hline & Any (via Sulfo-SANPAH) & $\begin{array}{l}\text { Can be performed by first activating either the surface or the protein. Other amine- and thiol-reactive photocrosslinkers } \\
\text { also exist }\end{array}$ & {$[69,108,109,250,251]$} \\
\hline & $\begin{array}{l}\text { Hydroxyl (via CDI, p-nitrophenyl } \\
\text { chloroformate disuccinimidyl } \\
\text { carbonate, succinic anhydride) }\end{array}$ & Reagents are generally sensitive to hydrolysis and reactions are commonly performed in organic solvents. & {$[46,252-257]$} \\
\hline & Anhydride & Rarely used & [258] \\
\hline & Epoxide & Fast and high yielding reaction. May also react with carboxylic acids. & [259] \\
\hline & Halogen & Can be performed in aqueous buffers. & [260] \\
\hline & Aldehyde & Aldehydes generated via oxidation of a PEG substrate & [261] \\
\hline & Isocyanate & Highly water sensitive reagents. & [262] \\
\hline & Phenoxy amino squarate & Targets only N-terminal cysteines. & [178] \\
\hline \multirow{6}{*}{$\begin{array}{l}\text { Carboxyl } \\
\text { Thiol }\end{array}$} & Amine (via carbodiimides) & Similar to attachment via amines, but more rarely used. Low efficiency coupling with some loss of bioactivity. & {$[11,113,175]$} \\
\hline & $\begin{array}{l}\text { Maleimide/acrylate/vinyl } \\
\text { sulfone, or amine if via SMCC } \\
\text { linker (Michael-type addition) }\end{array}$ & High yielding and moderately fast. & {$[48,103,107,183,193]$} \\
\hline & Double bond (thiol-ene) & $\begin{array}{l}\text { UV photocatalysed reaction (or radicals), not to be confused with Michael additions to similar groups. Specific and } \\
\text { high-yielding under aqueous conditions. }\end{array}$ & {$[71,219,263]$} \\
\hline & Dithiopyridine crosslinker & $\begin{array}{l}\text { Forms a disulfide linkage that can be reversed using reducing agents. Homobifunctional linker which may require care to } \\
\text { avoid self-crosslinking. Crosslinker has poor aqueous solubility, may require solvent [125]. }\end{array}$ & {$[13,103,183]$} \\
\hline & Metal e.g. gold & Used to conjugate adhesion peptides to gold nanoparticles. & {$[109,264-268]$} \\
\hline & Haloacetyl & Rarely used for ligand coupling & {$[183,185]$} \\
\hline $\begin{array}{l}\text { Naturally occurring } \\
\text { amino acid sequence }\end{array}$ & $\begin{array}{l}\text { Heparin, other ECM } \\
\text { components, sulfonated } \\
\text { substrates }\end{array}$ & $\begin{array}{l}\text { Peptide sequences discovered in growth factors, which sequester the GF to the ECM. Sequences used may occur in the } \\
\text { ligand naturally or can be introduced (from other GRs) using recombinant proteins or during peptide synthesis. }\end{array}$ & {$[148]$} \\
\hline Glycan & $\begin{array}{l}\text { Glycan (lectin mediated } \\
\text { binding) }\end{array}$ & May allow cells to dynamically remodel their environment & [269] \\
\hline Alkyne & Azide (CuAAC) & $\begin{array}{l}\text { Bio-orthogonal reactive groups. Copper catalyst, which can potentially be disruptive to cells and proteins if not } \\
\text { completely removed. Theoretically highly efficient reaction but can be slow without catalyst, and most protocols use }\end{array}$ & {$[157,216]$} \\
\hline Azide & $\begin{array}{l}\text { Alkyne (CuAAC) } \\
\text { Cyclooctyne (Copper-free click) }\end{array}$ & $\begin{array}{l}\text { large amounts of ligand. } \\
\text { Not used previously for ligand conjugation, but has been used for gel formation in the presence of cells. Removes the need } \\
\text { for a copper catalyst. }\end{array}$ & $\begin{array}{l}{[199,215]} \\
{[219]}\end{array}$ \\
\hline Aryl azide & $\begin{array}{l}\text { Amine or reactive hydrogen } \\
\text { (effectively none required) }\end{array}$ & $\begin{array}{l}\text { UV-activated linking of pre-activated ligands. Superior to methods involving SANPAH crosslinker due to site-specific } \\
\text { incorporation of the photoactive group. }\end{array}$ & [202-204] \\
\hline Diene & $\begin{array}{l}\text { Dienophile e.g. maleimide } \\
\text { (Diels-Alder) }\end{array}$ & $\begin{array}{l}\text { Bio-orthogonal reaction. Slower than other click reactions [212]. If using maleimide as the dienophile, thiols in the ligand } \\
\text { may require protection. Water is an ideal solvent for this reaction. }\end{array}$ & {$[205,221-224]$} \\
\hline $\begin{array}{l}\text { Ketone/aldehyde } \\
\text { Oxyamine }\end{array}$ & $\begin{array}{l}\text { Oxyamine (Oxime ligation) } \\
\text { Ketone/aldehyde }\end{array}$ & $\begin{array}{l}\text { Stable bond, nearly bio-orthogonal reactive groups (aldehydes may react with amines under some conditions), mild } \\
\text { conditions, no catalyst required. }\end{array}$ & $\begin{array}{l}{[171,232,233,270]} \\
{[225-230]}\end{array}$ \\
\hline Acrylate & Acrylate & Used in 3D photopatterning & {$[234,271-273]$} \\
\hline $\begin{array}{l}\text { Biotin (also proteins } \\
\text { with high-affinity } \\
\text { partners) }\end{array}$ & $\begin{array}{l}\text { Appropriate binding partner } \\
\text { (e.g. avidin derivative for biotin) }\end{array}$ & $\begin{array}{l}\text { Very high coupling yield under simple conditions. Binding partner must first be immobilised to the substrate, which can } \\
\text { be achieved in a number of ways. }\end{array}$ & {$[99,201,210,211,240]$} \\
\hline Hexa-histidine ("His6") & $\mathrm{Ni}$ or $\mathrm{Zn}$ activated substrate & Reversible binding. Possibly results in oriented attachment. & {$[37,206,207,209,241,242]$} \\
\hline Peptide sequence & Synthetic polymers & $\begin{array}{l}\text { Sequences are discovered via phage display, which bind to various synthetic polymers. Similar affinities available to } \\
\text { sequences found in growth factors. }\end{array}$ & {$[209,246-248]$} \\
\hline
\end{tabular}

Hydroxyl (via CDI, p-nitrophen (n)

Epoxide

Aldehyde

Double bond (thiol-ene) .

Rarely used for ligand coupling

Peptide sequences discovered in growth factors, which sequester the GF to the ECM. Sequences used may occur in the (aphe required) (Diels-Alder) . 
Table 6

Ligand patterning techniques that are able to achieve sub-cellular pattern resolution.

\begin{tabular}{|c|c|c|c|c|c|c|c|}
\hline Technique & $\begin{array}{l}\text { Resolution/smallest } \\
\text { feature size }\end{array}$ & $\begin{array}{l}\text { Process notes: } \\
\text { throughput, } \\
\text { serial/parallel } \\
\text { patterning }\end{array}$ & Arbitrary patterns? & 3D patterns? & Equipment notes & Substrates & $\begin{array}{l}\text { General notes and } \\
\text { ideal applications }\end{array}$ \\
\hline $\begin{array}{l}\text { Micro/nano- } \\
\text { contact } \\
\text { printing }\end{array}$ & $\begin{array}{l}1 \mu \mathrm{m} \text { standard, } \\
<100 \mathrm{~nm} \text { with } \\
\text { advanced stamp } \\
\text { materials }\end{array}$ & $\begin{array}{l}\text { High throughput } \\
\text { (parallel) after the } \\
\text { initial master is } \\
\text { made }\end{array}$ & Yes & No & $\begin{array}{l}\text { Cleanroom } \\
\text { required for master } \\
\text { template, } \\
\text { otherwise setup is } \\
\text { accessible }\end{array}$ & $\begin{array}{l}\text { Applicable to rough } \\
\text { or curved 2D } \\
\text { substrates. }\end{array}$ & $\begin{array}{l}\text { Co-patterning of } \\
\text { multiple ligands is } \\
\text { difficult. Changes } \\
\text { of pattern require a } \\
\text { new master. } \\
\text { Otherwise, a very } \\
\text { common method, } \\
\text { easily accessible, } \\
\text { low cost }\end{array}$ \\
\hline Photopatterning & $\begin{array}{l}\text { Typically } 1 \mu \mathrm{m} \text {; } \\
80 \text { nm with } \\
\text { multiphoton laser } \\
\text { ablation of a thin } \\
\text { film }\end{array}$ & $\begin{array}{l}\text { Serial or parallel, } \\
\text { depending on } \\
\text { method }\end{array}$ & Yes & Yes & $\begin{array}{l}\text { Some techniques } \\
\text { may require } \\
\text { specialised } \\
\text { equipment. Other } \\
\text { techniques have } \\
\text { been developed } \\
\text { recently using } \\
\text { easily accessible } \\
\text { equipment }\end{array}$ & $\begin{array}{l}\text { Can be applied to } \\
\text { non-flat 2D and 3D } \\
\text { substrates. } \\
\text { Specialised } \\
\text { substrate } \\
\text { chemistry is often, } \\
\text { but not always, } \\
\text { required. Optically } \\
\text { clear gels required } \\
\text { for 3D patterning }\end{array}$ & $\begin{array}{l}\text { The only technique } \\
\text { that has been } \\
\text { applied to pattern } \\
\text { in } 3 \mathrm{D} \text { at } \\
\text { sub-cellular } \\
\text { resolution. } \\
\text { Multiple } \\
\text { techniques give } \\
\text { versatility. }\end{array}$ \\
\hline $\begin{array}{l}\text { Electron beam } \\
\text { lithography }\end{array}$ & $\begin{array}{l}100 \mathrm{~nm} \text { shown, } \\
\text { theoretically much } \\
\text { smaller }\end{array}$ & $\begin{array}{l}\text { Low throughput } \\
\text { serial patterning }\end{array}$ & Yes & No & $\begin{array}{l}\text { Expensive } \\
\text { equipment and } \\
\text { usually cleanroom }\end{array}$ & $\begin{array}{l}\text { Specialised } \\
\text { substrate } \\
\text { chemistry required. } \\
\text { Only 2D substrates. }\end{array}$ & $\begin{array}{l}\text { Potential for very } \\
\text { high resolution } \\
\text { arbitrary patterns }\end{array}$ \\
\hline AFM techniques & $\begin{array}{l}30-40 \mathrm{~nm} \text { for } \\
\text { biomolecules, } \\
10 \mathrm{~nm} \text { achieved in } \\
\text { other settings. }\end{array}$ & $\begin{array}{l}\text { Low throughput } \\
\text { (serial but can be } \\
\text { parallelised using } \\
\text { arrays of AFM tips) }\end{array}$ & Yes & No & $\begin{array}{l}\text { Basic setup } \\
\text { accessible but can } \\
\text { be difficult to } \\
\text { optimise }\end{array}$ & $\begin{array}{l}\text { Requires a very flat } \\
\text { 2D substrate e.g. } \\
\text { SAM on silicon } \\
\text { wafer }\end{array}$ & $\begin{array}{l}\text { Arbitrary patterns } \\
\text { at high resolutions. } \\
\text { Can be very slow. }\end{array}$ \\
\hline $\begin{array}{l}\text { Colloidal } \\
\text { lithography }\end{array}$ & 100 nm shown & Parallel & No & No & $\begin{array}{l}\text { Some specialised } \\
\text { etching equipment } \\
\text { required }\end{array}$ & Only 2D substrates & $\begin{array}{l}\text { Can pattern large } \\
\text { areas quickly. Used } \\
\text { for studies on } \\
\text { integrin clustering. }\end{array}$ \\
\hline $\begin{array}{l}\text { Micellar } \\
\text { lithography } \\
\text { (with GNPs) }\end{array}$ & $8 \mathrm{~nm}$ & Parallel & $\begin{array}{l}\text { No, but patterns } \\
\text { are highly regular }\end{array}$ & No & $\begin{array}{l}\text { Specialised } \\
\text { equipment } \\
\text { required both for } \\
\text { forming the } \\
\text { micelles and } \\
\text { patterning }\end{array}$ & Only 2D substrates & $\begin{array}{l}\text { Low variation in } \\
\text { ligand spacing, } \\
\text { particularly for a } \\
\text { bottom-up } \\
\text { method. Has been } \\
\text { used extensively } \\
\text { for studies on } \\
\text { individual integrin } \\
\text { receptor spacing }\end{array}$ \\
\hline $\begin{array}{l}\text { Island-forming } \\
\text { block } \\
\text { copolymers and } \\
\text { blends }\end{array}$ & $\sim 20$ nm shown & Parallel & No & No & $\begin{array}{l}\text { Relatively } \\
\text { accessible }\end{array}$ & $\begin{array}{l}\text { Patterning is an } \\
\text { integral part of the } \\
\text { substrate } \\
\text { chemistry }\end{array}$ & $\begin{array}{l}\text { Can pattern large } \\
\text { areas quickly. Used } \\
\text { for studies on } \\
\text { integrin clustering. }\end{array}$ \\
\hline
\end{tabular}


Here we discuss techniques used to create twoand three-dimensional patterns of receptor ligands, and present a summary in Table 6 . We discuss briefly the need to present particular ligands in close proximity to each other for optimum activation of receptors. We also discuss techniques that have been used to vary ligand presentation over time. In this section we limit discussion to patterning on a sub-cellular $(<5 \mu \mathrm{m})$ scale. While patterning of ligands into larger microscale patterns (e.g., arrays for combinatorial screening of cell-substrate interactions [93,94,141] or substrates for controlled colony sizes [278]) is undoubtedly useful technology, we will focus on patterning ligands at a scale where the patterns can have a direct effect on singlecell signaling. We also limit discussion on topographical patterns, which are reviewed elsewhere [279].

This section will focus where possible on studies that have immobilized receptor binding ligands, rather than other commonly investigated proteins such as BSA or IgG; although we acknowledge the relevance of these studies to a methods-based discussion, there is not scope within this review to examine methods that have not been used to create cell culture substrates.

\subsection{Two-dimensional patterning}

Several recent reviews exist that cover spatial patterning of 2D substrates with peptides or proteins, with applications in cell culture substrates [274,280-284]. Here we will summarize these and include discussion of other recent studies.

\subsubsection{Stamping}

Microcontact printing $(\mu \mathrm{CP})$ is a well-established and versatile method for ligand patterning [285-287]. A master pattern is generally created in silicon wafer or a similar material, typically using photolithography or in some cases electron beam lithography. A soft elastomeric stamp, typically made from PDMS (polydimethylsiloxane), is then molded from the master, cured and removed. The stamp is "inked" with molecules that are to be placed on the surface, either proteins/peptides or functional molecules to which proteins/peptides can later be attached. The stamp is pressed onto the surface and the pattern transfers through either adsorption or reaction with surface functional groups.

This approach is used for patterning on a micron scale, although several techniques can be used that allow sub-100 nm patterns to be created (known as nanocontact printing, nCP). These use harder materials in the elastomeric stamp that prevent sagging [285,288,289]. Stamping using these methods can pattern large areas easily and inexpensively, and can deal with many non-flat, curved and otherwise non-uniform surfaces. It is difficult to co-pattern multiple factors accurately, as the stamp cannot be perfectly realigned. Access to facilities for creating master patterns can be an issue for more biologically-focussed labs [275], although once the master is made it can be reused many times.

Micro/nano-contact printing has been used in several studies investigating the effects of patterned integrin ligands on cell attachment, spreading, focal adhesion formation and migration on self assembled monolayers [290-295]. In a typical approach, patterns of functional alkanethiols are created, the substrate is backfilled with protein-repellant PEG-thiols, and then ligands are attached through either adsorption [291,294] or covalent bonding [292]. Alternatively, proteins such as fibrinogen (an ECM component) [288] or EphrinA5 (a neuronal guidance protein) [296] have been patterned directly from the stamp; however, it is noted that a small subset of proteins could lose bioactivity during direct (as opposed to indirect) patterning.

\subsubsection{Photopatterning and electron beam lithography}

Using light (particularly UV light) to pattern ligands is another common approach used for spatial patterning and several different techniques exist for the creation of complex patterns [297]. Patterns can be formed by either masking or maskless techniques. Photomasks are created using etchable spun-coated resist layers, or by creating a reusable mask, while maskless patterning techniques include interference lithography, single laser beams and multiphoton laser stimulation [289].

Indirect patterning, where ligands are attached to a prepatterned reactive group, can be achieved by activation of a protected group such as an 0 -nitrobenzyl derivative. Previous work has patterned receptor ligands on deprotected surfaces displaying carboxyls [298,299], aldehydes [230], ketones [227], oxyamines [270], thiols [211,252], and quinones (via protected, then reduced hydroquinones) [223]. Christman et al. used a photoacid generator to reveal a Boc-protected amine [232], while Alang Ahmad et al. degraded PEG-based films to create aldehydes [261]. Masking can also allow direct patterning of ligands that contain photoreactive groups such as aryl azides [202], while recent work has demonstrated that the $\mathrm{CuAAC}$ reaction may also be controlled with photostimulation, although not currently with the resolutions being discussed here [300]. A visual summary of covalent chemistries used in ligand patterning studies is included in Fig. 6.

Tightly focussed single-beam laser sources can also be used for surface patterning [252], but to date these approaches have not been able to achieve resolution at sub-cellular scale. However, two- or multi-photon techniques can be used to improve the situation, creating 2D patterns of multiple ECM proteins at sub-micron resolution [301]. One recent study used multiphoton laser ablation to ablate grafted PEG films from a surface [236]. This technique could be used to fabricate arbitrary patterns with a resolution down to $80 \mathrm{~nm}$, well below the diffraction limit of the laser, however the laser equipment used in this technique is rather rare and expensive. Two-photon irradiation has also made 3D post hoc patterning of optically clear hydrogels a possibility (see Section 4.2).

Several studies have also developed novel methods that require little in the way of specialized equipment, thus making them accessible to bio-focused laboratories. These techniques use illumination from standard fluorescence microscopes, along with various responsive chemistries, including nitrobenzyl ether cleavage 
R1 and R2 substituents in the nitrobenzyl ether affect kinetics and absorption properties of the reaction.<smiles>[R]C(=O)OC([R])c1cc([R])c([R])cc1[N+](=O)[O-]</smiles>

[298]: R1 = OMe, R2 = H [299]: $R 1=H, R 2=M e$<smiles>C/C=C\C(=C/C)COC(=O)Oc1ccc(O)c(PC)c1</smiles>
$\lambda=365 \mathrm{~nm}$
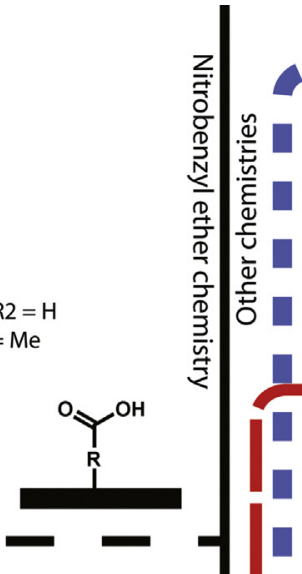

$+\sqrt{10}$

\section{Direct patterning}

$\square \square \square \square$
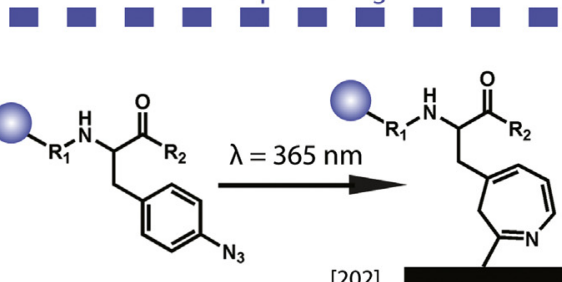

[202]

3D patterning

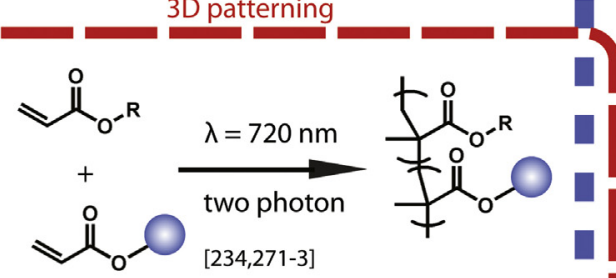

[223]: Used as dienophile [227]: Used as ketone

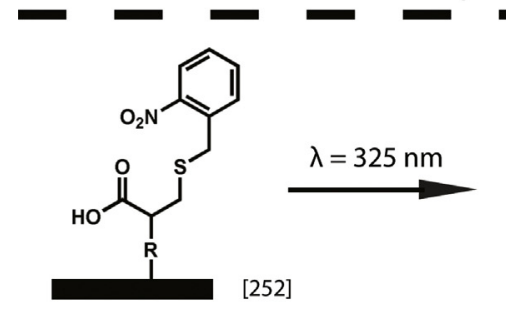

$\lambda=365 \mathrm{~nm}$ A further
oxidation step

[252]
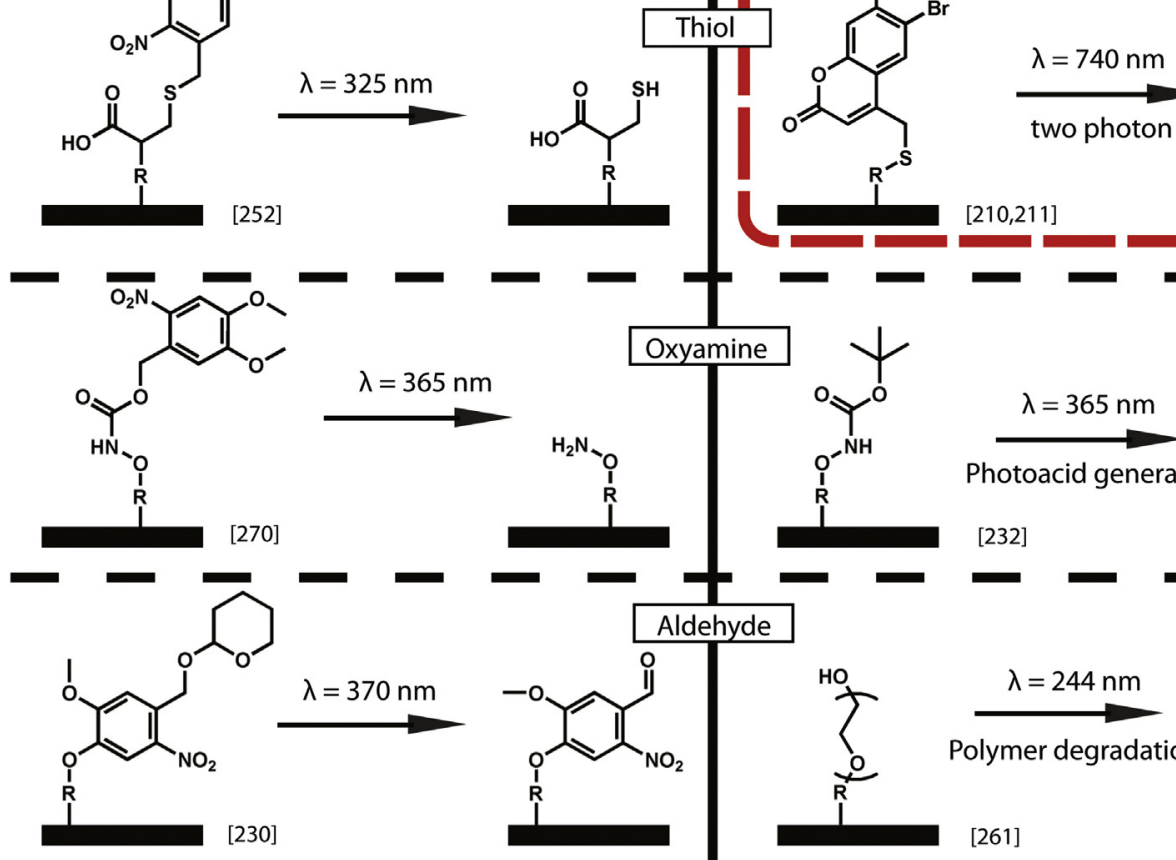

Photoacid generato

[232]

$\lambda=740 \mathrm{~nm}$

two photon

[210,211]
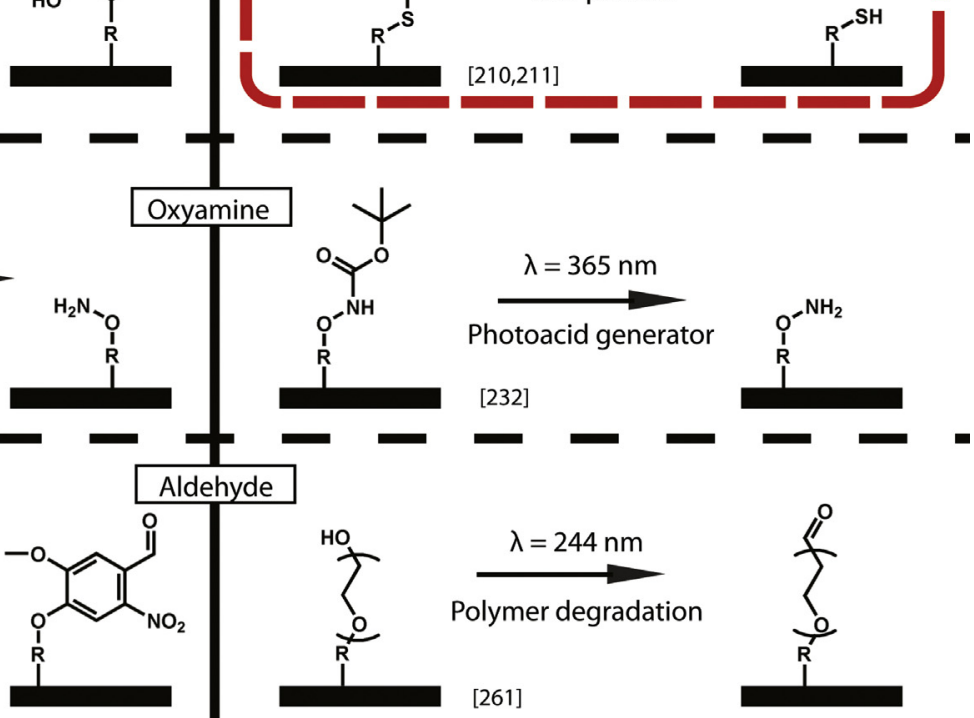

$\lambda=244 \mathrm{~nm}$

Polymer degradation

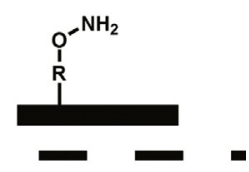

[261]

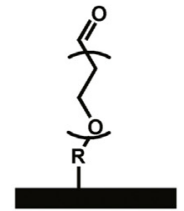

Fig. 6. A summary of selected covalent coupling chemistries used for UV-mediated patterning of ligands. Techniques are grouped according to common features. Photomediated reactions used to pattern ligands directly to a surface under UV irradiation are presented within the blue loop, while the remaining techniques use the indirect approach of patterned deprotection of reactive groups, followed by reaction with an appropriately functionalised ligand. A range of reactive groups can be revealed following removal of nitrobenzyl ether (left) or other protective groups (right). Dotted black lines group indirect techniques that reveal the same reactive groups following deprotection. Within the red loop are reactions that have been used with two photon stimulation to create three dimensional patterns within hydrogels. (For interpretation of the references to color in this figure legend, the reader is referred to the web version of the article.) 
[298,299], and another technique which uses a photobleaching reaction to attach a biotin-fluorescein conjugate to the surface [302]. They retain the ability to pattern at resolutions of approximately $1 \mu \mathrm{m}$, and in many cases can also create patterns of multiple proteins.

Alternatively, electron beam lithography (EBL) has shown potential for creating patterned surfaces with features that are smaller than those possible when using photopatterning. The major restriction on photopatterning resolution is the wavelength of the light used. Based on this criterion EBL could achieve resolution down to below the size of single receptors, although as yet this has not been demonstrated. Use of EBL for biomolecule patterning was reviewed by Kolodziej and Maynard [303]. While it offers access to arbitrary patterns at high resolution, EBL is also low throughput and high cost, may require a conductive substrate and may be unavailable to many researchers [303].

Pesen and Haviland were able to co-pattern fibronectin and laminin on polymer-coated silicon wafers, creating dots, rings and lines with feature sizes from microns down to $150 \mathrm{~nm}$ [304]. Patterning of PEG-based substrates has also been used, to create laminin stripes that affected cell polarization [305], or co-patterns of multiple (up to 4) peptides/proteins $[170,171,239]$. In an unconventional approach, Rundqvist et al. used an electron beam to locally inactivate fibronectin, leading to cell adhesion only in unexposed areas [306].

\subsubsection{Scanning probe methods}

Dip-pen nanolithography (DPN) [280,307,308] and other atomic force microscope (AFM) based techniques such as nanoshaving of SAMs [280] offer high resolution and arbitrary patterning under mild conditions. These methods have been used in many studies for patterning proteins and peptides, including in studies aiming to stimulate receptor signaling. Typically this technique is used on SAM-coated surfaces, as the technique could be difficult to employ on non-flat surfaces. An indirect patterning method may be used, where alkanethiols with appropriate functional groups are patterned and the remaining space is backfilled with PEG functionalized thiols $[228,229,309]$. With this approach, resolution down to $100 \mathrm{~nm}$ has been achieved [309]. Direct patterning of proteins has also been demonstrated. Wilson et al. directly patterned thiolated collagen onto a gold substrate with $40 \mathrm{~nm}$ resolution [310]. While DPN has been shown to have a general resolution down to $10 \mathrm{~nm}$, this resolution has yet to be demonstrated in direct DPN with proteins or other ligands [307], although it has been achieved using the nanoshaving technique [280,311]. There is also potential to independently pattern multiple ligands using this technique. Sekula et al. describe a system for DPN co-patterning of biotin and Ni-NTA moieties, and subsequent stability of an antibody pattern under cell culture conditions, which could seemingly be adapted for ligand presentation [312]. Throughput with a single tip is very low, however this can be increased using multitip systems [307]. One review of the area also notes that optimization of these systems can be time consuming [274].

\subsubsection{Techniques utilizing self-assembly of nanospheres} on a surface

Colloidal/nanosphere lithography techniques have been used by several groups for general protein patterning. Suspensions of essentially monodisperse colloidal particles are used as a mask, allowing the surface to be modified in those areas not obscured. Sutherland et al. used the technique to create fibronectin spots of between 100 and $1000 \mathrm{~nm}$ to examine integrin clustering [313-315], while a related technique was used to form triangular functionalized areas between the spheres [316]. Large areas can be patterned simultaneously using this technique, however, as can be seen in Fig. 7, spacing between the functional domains can be irregular.

Spatz and coworkers developed a method, termed "block copolymer micelle nanolithography," using gold nanoparticles (GNPs) to control spacing between individual receptor-ligand complexes. GNPs were encapsulated within a diblock polymer micelle of controlled size, and these were allowed to pack into hexagonal arrays onto a surface. The polymer was then removed, leaving a pattern of GNPs with a consistent spacing, as seen in Fig. 8 [264,266]. GNPs are functionalized with ligands using metal-thiol bonds. GNP size was kept small enough to prevent more than one receptor interacting with each particle. The regularity of patterning and the ability to localize clusters of ligands with sub-receptor sized resolution $(8 \mathrm{~nm}$ [264]) makes this a powerful method. Several later studies have led to important insights into links between individual receptor spacing and attachment events such as focal contact formation or tension within bound integrins [109,265,267,268].

\subsubsection{Block copolymers and polymer blends}

Blended polymer systems have been used to adjust the average spacing between ligands [29,317-320], where one component of the system is functionalized with ligand, while the other is left inert. Variable numbers of ligands per functionalized component allow overall density and clustering to be independently controlled. In an alternative approach, block copolymers can self-assemble to present nanodomains of functionalizable polymer on a low-fouling background (see Fig. 9) [321,322].

As "bottom-up" methods, these systems may have more variable spacing between ligands than "top-down" methods. However these materials do not require specialized equipment, are much simpler to implement, and can create patterns at higher resolution than many top-down approaches. Methods for increasing the regularity of these patterns would be of use, and considerations of any surface mobility of domains in these materials should be taken into account.

\subsection{Three-dimensional patterning}

Few methods have yet been devised that allow the patterning of ligands within 3D environments at the resolutions being examined here. One recent approach uses two photon irradiation to initiate covalent attachment with 3D spatial control, and examples of chemstries used with this technique are highlighted in Fig. 6. Resolution down 

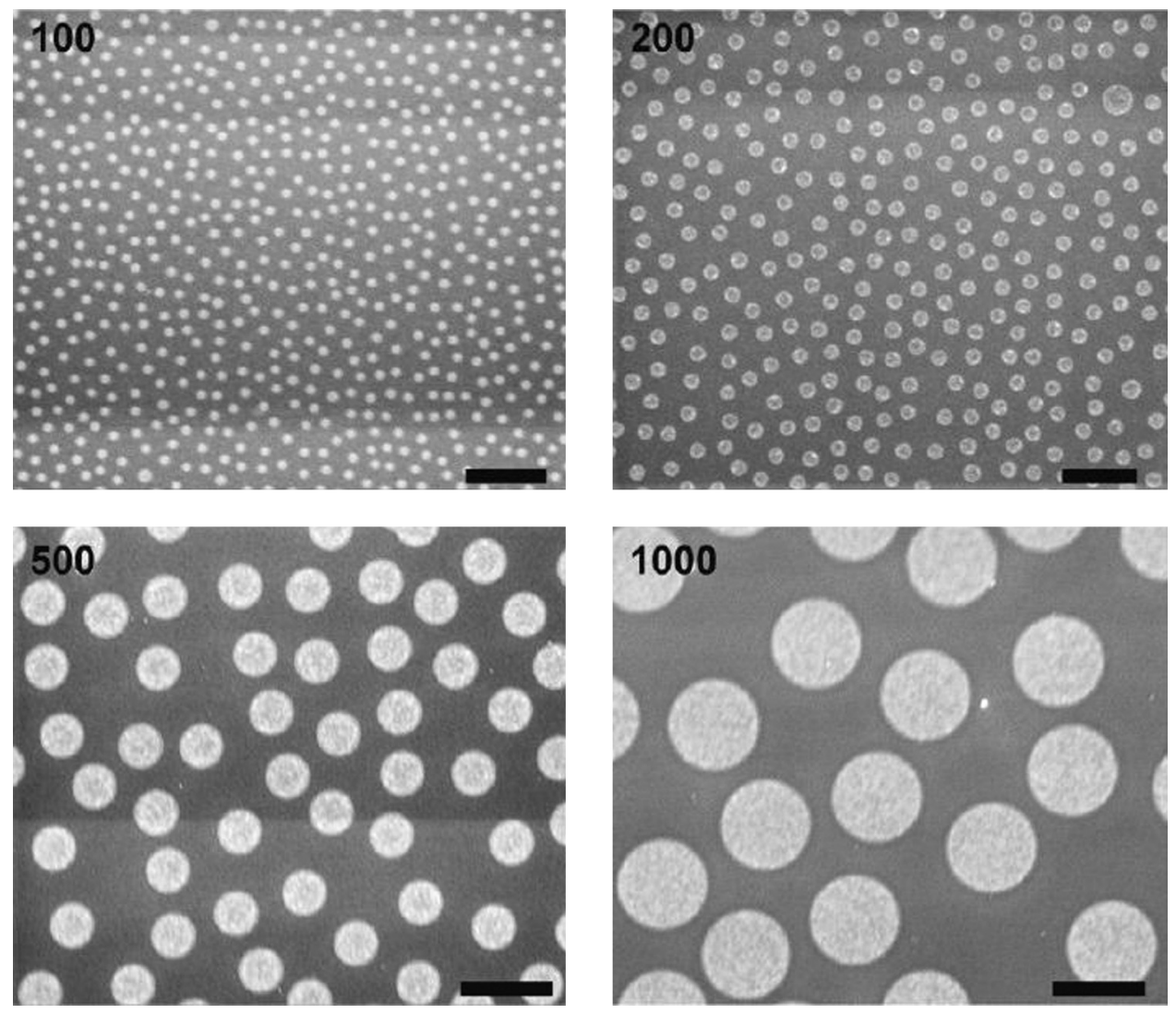

Fig. 7. Patterning via colloidal lithography. Colloidal particles of varying sizes (100-1000 nm) are deposited on a surface and used as a mask to create controlled-size patches of material that were later functionalised with adhesion ligands.

[314], Copyright 2010. Reproduced with permission from the American Chemical Society.

to $1 \mu \mathrm{m}$ can be achieved [263] depending on the equipment used and plane of interest (resolution in the $x-y$ plane can be an order of magnitude better than in the $z$ plane). While the process is labor-intensive, the ability to create arbitrary patterns of ligands within a three-dimensional scaffold could enable many interesting studies of ligand patterning and cell behavior.

Several different groups have published patterning methods using this technique. The Shoichet group used two photon UV light to deprotect coumarin-caged thiols, which were then reacted with maleimide-containing proteins in three dimensions [211]. Following the initial deprotection, reaction of thiols with maleimide-barnase, and subsequent quenching, the process was repeated to pattern a second protein, maleimide-streptavidin. Streptavidin and barnase proteins were then used to attach biotin- and barstar-containing ligands via affinity interactions, creating patterns of two different signals. Anseth and coworkers used thiol-ene chemistry in several studies to pattern an RGD peptide in 3D within an independently photodegradable gel [71,219,263]. Using appropriately designed RGD ligand, containing both a cysteine for thiol-ene attachment and an $o$-nitrobenzyl ether photo-labile group for cleavage, they were able to show spatiotemporally controlled attachment and then release of the RGD ligand [263]. The West group used two-photon activation to react acrylated peptides with free acrylates within a PEG hydrogel to achieve 3D patterning [271-273]. This method was also adapted to create patterns comprising more than one peptide [234].

Otherwise, top-down patterning in $3 \mathrm{D}$ is currently limited to lower resolutions (tens to hundreds of microns) than those discussed here, although technologies such as 3D printing are approaching relevant resolutions [323]. Alternatively, bottom-up strategies that create clusters of ligands within 3D hydrogels may be useful [324].

\subsection{Spatially controlled co-presentation of different ligands}

Having two binding motifs within close proximity may be desired, such as in the well-known case of PHSRN and RGD, two small peptide sequences within (respectively) the 9th and 10th type III domains of fibronectin. Co-presenting PHSRN with RGD has been found to increase affinity of RGD for $\alpha_{5} \beta_{1}$ integrins compared to $\alpha_{v} \beta_{3}$, and hence PHSRN is occasionally known as the "synergy" sequence [325]. For this interaction, PHSRN and RGD must be presented close enough to each other to bind to the same receptor, and may also need to be presented in a particular relative orientation [2].

Several different techniques have been used to copresent these two peptide ligands, while avoiding the complications associated with the myriad of active sites 

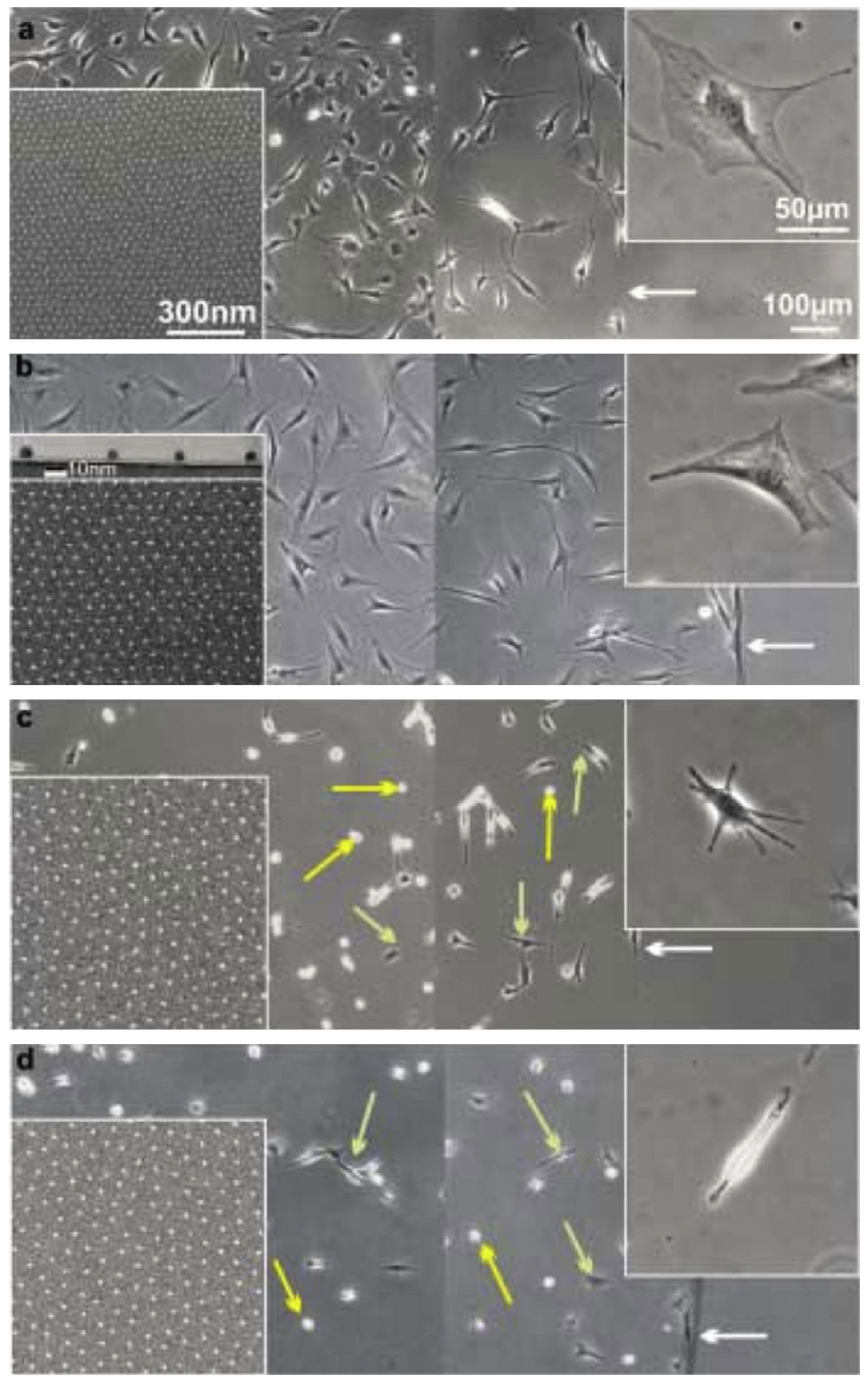

Fig. 8. Arrays of consistently spaced RGD-functional gold nanoparticles and subsequent cell adhesion. Closely spaced RGD ligands supported cell adhesion, while cells did not adhere above a threshold of $73 \mathrm{~nm}$. Images show nanoparticles with average spacing of (a) $28 \mathrm{~nm}$, (b) $58 \mathrm{~nm}$, (c) $73 \mathrm{~nm}$, and (d) $85 \mathrm{~nm}$. Due to the size of the particle used, only (at most) a single integrin receptor should bind to each nanoparticle.

[264], Copyright 2004. Reproduced with permission from John Wiley \& Sons.

in whole fibronectin. The simplest of these involves independently presenting RGD and PHSRN peptides [71]. In this case, no synergistic effects on cells were reported, and considering that close spatial coupling seems to be important, these may have been minimal. On the other hand, Ochsenhirt et al. co-presented GRGDSP and PHSRN peptides independently within a Langmuir-Blodgett film and observed increased cell spreading [325]. 

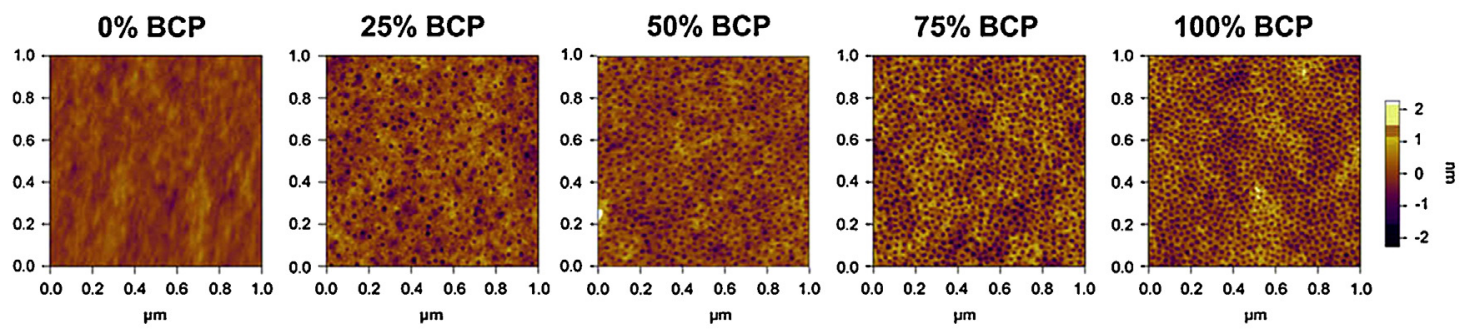

Fig. 9. AFM image of polystyrene-block-poly(ethylene oxide) copolymer domains which assemble due to phase separation in blends with polystyrene homopolymer. Dark spots show the presence of block copolymers containing maleimide functional groups that can later be conjugated to receptor ligands. Variable spacing of domains is achieved by altering blend composition.

[321], Copyright 2009. Reproduced with permission from Elsevier Ltd.

Fusion peptides that link the two motifs with polypeptide spacers have also been found in several studies to show increased cell adhesion [326-328]. These peptides can be produced using solid-phase peptide synthesis, with the use of polyglycine spacers allowing the distance between motifs to be controlled. However, orientation is potentially not controlled, and the peptide is likely very flexible. Petrie et al. did not find any increase in adhesion when using these types of spacers, and found that a fusion peptide of this type still bound through $\alpha_{V} \beta_{3}$ integrins rather than $\alpha_{5} \beta_{1}$ [22]. Further work may still be required to elucidate the interactions between these two binding sites when co-presented in a fusion peptide.

A final method of ligand co-presentation uses a protein fragment, such as the 9-10th $[23,329]$ or $7-10$ th $[22,142,206]$ type III domains of fibronectin, rather than short peptides. Consequently, this method requires recombinant production of the protein fragment, rather than the simpler solid-phase peptide synthesis, but is more likely to control both the spatial and orientational relationship between RGD and PHSRN and lead to higher $\alpha_{5} \beta_{1}$ integrin activation than the previous methods [22]. However, binding may be able to be improved even further; Martino et al. showed that initial MSC adhesion and $\alpha_{5} \beta_{1}$ specificity to the 9-10th fragment was increased by using a mutated version of the protein [23]. This increase in binding was purportedly caused by a stabilized protein structure in the mutated fragment. Both fragments showed increased specificity compared to whole fibronectin, which contains multiple binding epitopes.

Co-presentation may also be required for other, as yet unidentified, groups of ligands in order to produce a desired biological effect. Other studies have focussed on copresentation of adhesion signals and growth factors, using similar methods to those discussed above $[93,237,330]$. For example, Elloumi et al. investigated the action of a fusion protein containing both EGF and RGD signals [330].

\subsection{Temporal patterning}

The in vivo cellular microenvironment is dynamic, and evolves through processes such as cellular deposition and enzymatic remodeling of ECM proteins [331-333]. In recent years the creation of cellular environments that have the ability to change over time has come to the fore of materials research. A large proportion of research in this area has focused on creating degradable microenvironments, particularly through the inclusion of short degradable linkers in hydrogel matrices, in order to allow cell migration. In contrast, the controlled temporal variation of ligand presentation is a relatively underexplored area of research.

Ligands may be physically encapsulated within the bulk scaffold material or within micelles or core-shell structures. However, we will limit the focus of this section to materials displaying time-varying ligands that are accessible to cells, rather than releasing them from internal reservoirs. For cohesion, we also restrict ourselves to degradation mechanisms that exclusively affect the ligand, and do not affect the bulk of the substrate, even though in native ECM the two may be interlinked.

\subsubsection{Passive release}

The natural affinity of many growth factors for binding to ECM proteins and GAGs such as heparin is commonly used to attach ligands to substrates and facilitate their controlled release. This approach was summarized in some detail in Sections 3.2.2 and 3.3.3. Passive release generally leads to an exponentially decaying release over a period of days to weeks. Vulic and Shoichet described a system where this exponential release could be tuned using a twocomponent system [334]. In order to modulate the release rate, they used recombinant FGF that contained an additional binding domain, and two different peptides on the substrate with different affinities for that binding domain. The ratio of the two binding peptides controlled the release rate.

Several types of linking chemistry are also sensitive to hydrolysation. We are unaware of any studies where hydrolysable linkages have been deliberately used for controlled slow release of ligands from a cell culture substrate, although this approach has been used for drug release from soluble PEG [335].

\subsubsection{Stimuli responsive spatiotemporal control: researcher-responsive changes}

Photodegradable linkers have been used to release RGD adhesion peptides from surfaces. Kloxin et al. described a system using a photocleavable RGD-acrylate monomer to incorporate the RGD ligand within a PEG acrylate hydrogel [336]. RGD could then be cleaved from the hydrogel 
in three dimensions and at controlled time points using UV irradiation, inactivating cell adhesion. DeForest and Anseth extended this, allowing for both spatially-controlled coupling and release [263]. This work used an RGD peptide with both thiol and $o$-nitrobenzyl functionalities within the spacer. The peptide was first photocoupled within a PEG hydrogel via a thiol-ene click reaction, and could then be photoreleased via the degradable $o$-nitrobenzyl ether group. del Campo and coworkers also describe a system that incorporated an o-nitrobenzyl-containing linker for spatially controlled RGD release [337]. Conversely, the same group described the use of a caged cyclic RGD ligand, which can be made accessible (rather than released) in the presence of cells through UV irradiation [338,339].

Auernheimer et al. used an alternative approach, linking RGD to a surface via azobenzene-based spacers [340]. These spacer molecules undergo photoisomerization (changing between the cis- and trans- forms of the molecule) that leads to fully-reversible conformational changes within the molecules. The presence or absence of photostimulation led to reversible changes in spacer length and the subsequent availability of RGD ligands to cells for attachment. Previous studies have also described the use of azobenzene groups within the structure (rather than the spacer) of cyclic RGD peptides to create photoswitchable RGD ligands, although these ligands were used in solution rather than for cell-surface adhesion studies [341,342].

Other systems have used the addition of enzymes [343], free coil domains [344], or electrochemical stimulation [345] to temporally control ligand presentation from substrates. These lack the spatial control of photoresponsive systems, although they may be able to be combined with photoactivatable chemistries [345].

\subsubsection{Stimuli responsive spatiotemporal control:} cell-responsive changes

Matrix metalloproteinases (MMPs) and plasmins are proteases released by cells and found within the extracellular environment. Peptide sequences that are sensitive to protease degradation are commonly used as crosslinkers in hydrogel systems; these crosslinkers are degraded during culture, reducing the modulus and mesh size of the hydrogels and allowing cells to proliferate and migrate [346]. However there is also scope to use these sequences within advanced spacer molecules to allow release without affecting gel structure [347].

Salinas and Anseth compared the effects of MMP-13cleavable RGD versus uncleavable RGD on chondronergic differentiation human mesenchymal stem cells in PEG hydrogels [348]. While integrin signaling was needed to initiate differentiation, the authors showed that latestage differentiation was increased when the RGD ligands were cleaved (via cell-secreted MMP-13) at an intermediate point of development. Another study used an RGD-degradable sequence fusion peptide as the crosslinker within a heparin/starPEG hydrogel [349]. Although RGD is not completely released within this system, degradation of the crosslinker may result in a change in accessibility of the RGD ligand, as well as reducing the modulus of the gel.

Otherwise, efforts at release have typically been targeted at growth factors, which often have short half-lives in vivo [350]. Zisch et al. showed that certain forms of VEGF contain plasmin-degradable sequences, which could be used to release covalently-immobilized VEGF [193]. Hubbell and coworkers created several different fusion proteins, containing various growth factors along with degradable sequences [351-353]. MMP-cleavable linkers have also been used to attach model proteins [233].

Cells may also modulate their own environment by releasing and rearranging ECM molecules [354]. A recent study aimed to create surfaces where ECM proteins could be rearranged by cells during culture using lectin-mediated binding, a novel method of protein attachment, that mimics in vivo ECM processes [269]. Lectins are proteins that bind to particular saccharide molecules, many of which are present in ECM glycoproteins and also on the outside of the cell membrane. This study used lectins as crosslinkers, to non-covalently bind ECM proteins to a pattern of surface-bound polysaccharides. They showed evidence of the rearrangement of fibronectin by fibroblasts, but did not examine other proteins; however, providing a well-controlled initial environment while allowing cells to dynamically remodel at later time points is an intriguing goal.

\section{Quantification of surface-bound ligand}

In order to investigate quantitative relationships between ligand presentation and subsequent cell activity, accurate characterization of ligand-functionalized substrates is vital. Many techniques, summarized below, are available to quantify ligand concentration. However, as has been discussed, ligand activity can change markedly upon attachment to a substrate. Quantification of the bioactivity of attached ligands is often neglected, and (as discussed in Section 5.2) is an area where further development would be welcome.

\subsection{Ligand density}

Techniques for determining ligand concentration are discussed in this section, including sensitivity limitations, measurement of patterns and heterogeneities, and practical issues such as simplicity and cost. A range of analysis methods, along with their respective advantages and disadvantages, is presented in Table 7.

Many hydrogel matrices can be created in such a way that their ligand content is defined, using protein, peptide and synthetic hydrogels. Hydrogels made from ECM proteins are easily quantified at a basic level (e.g., $2 \mathrm{mg} / \mathrm{ml}$ collagen), but many of the protein-cell interactions are not well defined. Short peptides, modified proteins or pre-modified synthetic polymers allow more rigorous quantification of the signals being received by cells, and can be characterized using standard methods such as nuclear magnetic resonance spectroscopy or mass spectrometry. Accurate and simple control of ligand density is an advantage of these systems, assuming that the ligands are incorporated quantitatively as expected; however we will limit the focus of this section to quantification 
Table 7

Summary of methods used for quantification of ligand density.

\begin{tabular}{|c|c|c|}
\hline Method & Advantages & Disadvantages \\
\hline \multicolumn{3}{|l|}{ Label-free, non-specific } \\
\hline Colorimetric assays & Simple. Inexpensive. & Lower sensitivity and precision. \\
\hline QCM/SPR & $\begin{array}{l}\text { Can monitor over time. SPR in particular can be very } \\
\text { sensitive, particularly for large proteins. }\end{array}$ & Require specialised surface, model 2D surfaces only. \\
\hline XPS & $\begin{array}{l}\text { Good surface specificity, typically }<10 \mathrm{~nm} \text { on polymer } \\
\text { substrates. Fluorine tagged ligands can be used in XPS for } \\
\text { specificity and increased sensitivity. }\end{array}$ & $\begin{array}{l}\text { Detection via nitrogen abundance has low sensitivity. } \\
\text { Modeling is required to calculate surface density. Ultra } \\
\text { high vacuum required. Expensive. }\end{array}$ \\
\hline IR spectroscopy & Simpler and less expensive than XPS. & $\begin{array}{l}\text { Poor surface specificity, lacks ability to quantify surface } \\
\text { density accurately. }\end{array}$ \\
\hline UV-vis spectroscopy & Good sensitivity and ability to quantify surface density. & Rarely used technique, may require labeling. \\
\hline ToF SIMS & $\begin{array}{l}\text { Spatial mapping of ligands without a fluorescent tag. Very } \\
\text { high surface specificity, which can be used to detect } \\
\text { protein orientation. }\end{array}$ & Difficult to use for density quantification. \\
\hline \multicolumn{3}{|l|}{ Label-free, ligand specific } \\
\hline ELISA & $\begin{array}{l}\text { Ligand specific detection without pre-labeling. Kits } \\
\text { available. May be able to measure bioactivity to some } \\
\text { degree. }\end{array}$ & $\begin{array}{l}\text { Antibodies must be available and of high quality. } \\
\text { Sensitivity is dependent on antibody activity and so } \\
\text { requires careful calibration. }\end{array}$ \\
\hline Soluble receptors & $\begin{array}{l}\text { Probes ligand affinity and availability. May be able to } \\
\text { detect changes in orientation/conformation of attached } \\
\text { ligands. }\end{array}$ & Rarely used technique. Requires a further detection step. \\
\hline Amino acid digestion & $\begin{array}{l}\text { Non-specific method that still gives an indication of ligand } \\
\text { type. }\end{array}$ & $\begin{array}{l}\text { Requires acid solution for digestion step. Less sensitive } \\
\text { than other techniques. Only used on hydrogel substrates at } \\
\text { this point. }\end{array}$ \\
\hline \multicolumn{3}{|l|}{ Labeled ligands } \\
\hline Fluorescence & $\begin{array}{l}\text { Simple visualisation of spatial distribution. Very } \\
\text { commonly used. Protocols using releasable tags can avoid } \\
\text { problems with quenching effects. }\end{array}$ & $\begin{array}{l}\text { Fluorescence may be partially quenched by surface } \\
\text { interactions. Protocols using releasable tags require more } \\
\text { involved protocols. Requires calibration. }\end{array}$ \\
\hline Radioactive tag & $\begin{array}{l}\text { Very high sensitivity }\left(\mathrm{fmol} / \mathrm{cm}^{2}\right) \text {. Some ability to examine } \\
\text { spatial variations. }\end{array}$ & Requires specialised equipment and safety protocols. \\
\hline
\end{tabular}

of ligands after they are immobilized on/within a substrate at an unknown density.

\subsubsection{Non-specific methods}

Non-ligand-specific methods such as colorimetric assays, resonance methods and spectroscopic methods can all be used to quantify the attachment of ligands. These rarely require a change in protocol for different ligands (although they may require new standards), but similarly are not generally able to distinguish between different ligands.

Colorimetric assays are inexpensive and simple, but may be unsuitable for accurate quantification at low densities or for small peptides. Several of these techniques are reviewed by Noble and Bailey [355]. Goddard et al. notes several advantages of the BCA (bicinchoninic acid) technique over other similar protein assays, which include increased sensitivity and ability to be used directly on a surface [43]. The Iwata group used a microBCA assay kit to directly determine protein concentrations on a surface down to $300 \mathrm{ng} / \mathrm{cm}^{2}$, with uncertainties in the order of $100 \mathrm{ng} / \mathrm{cm}^{2}$ [207,209]. Boucher et al. also used the BCA assay to detect a modified EGF ligand down to $120 \mathrm{ng} / \mathrm{cm}^{2}$, with variations of approximately $\pm 60 \mathrm{ng} / \mathrm{cm}^{2}$, by comparing the concentration of ligand in the conjugation solution before and after the reaction [38]; however indirect quantification methods have many drawbacks including lowered reliability compared to direct techniques. In particular, ligands may loosely adsorb to the surface during conjugation, but then removed during subsequent washing, leading to an overestimate of attached ligand density. Furthermore, published protocols have used bovine serum albumin rather than the protein of interest as a calibration standard, which could decrease the accuracy of the assay.

Surface plasmon resonance (SPR) and quartz crystal microbalance techniques ( $\mathrm{QCM}$ ) both rely on detecting resonance effects of deposited material. Unlike other methods, they can be used to monitor deposition kinetics continuously in real time. Each technique requires its own specialized substrate. Although these substrates can be modified, for example by spin coating a thin layer of polymer, this requirement can limit their usefulness outside of model systems.

QCM uses changes in the resonant frequency of a piezoelectric crystal to monitor mass that is either adsorbed or coupled to the surface. Commonly it also monitors energy dissipation at the resonant frequency, which can be related to viscoelastic properties of the surface. QCM can easily detect frequency changes that correspond to masses down to $10 \mathrm{ng} / \mathrm{cm}^{2}$, and a resolution down to $2 \mathrm{ng} / \mathrm{cm}^{2}$ may be obtainable in some systems [356]. While some modeling may be required (due to coupled water at the surface or within a polymer layer), the techniques for this are relatively well established. However, besides the adsorption of large extracellular matrix proteins, QCM is rarely used for quantifying ligand attachment to surfaces. More often, it is used to monitor protein adsorption processes, particularly in low-fouling materials [313,357].

SPR is more sensitive than QCM, with a lower detection limit of approximately $0.1 \mathrm{ng} / \mathrm{cm}^{2}$, although the method of measurement is quite different [358]. This technique 
examines the propagation of electromagnetic waves across a gold substrate, which is stimulated by an incident beam of light. At different angles of incidence, light is absorbed or reflected at different ratios, with a reflection minimum at a resonant angle. The buildup of thin layers causes a detectable change in this resonant angle, and with the application of certain assumptions as to this relationship, mass deposition can be quantified [359]. SPR is more commonly used for protein attachment quantification than QCM. In particular, the ease with which SPR can be used to investigate binding kinetics has made it particularly popular for examining affinity-based attachment (and release) of ligands $[37,155,170]$. One study used SPR to examine the interaction between soluble integrin receptors (as discussed in Section 5.1.2) and surfaces that contained a synthetic integrin ligand bound to a surface, and in particular their specificity to $\alpha_{v} \beta_{3}$ integrins over other types [33]. Another study quantified the amount of immobilized heparin on a substrate, and subsequently the amount of VEGF that bound to that heparin layer. In that study, $0.1 \mathrm{ng} / \mathrm{cm}^{2}$ of VEGF was detected, close to the lower limit of resolution for this technique [52].

Spectroscopic methods such as X-ray photoelectron spectroscopy (XPS), infrared (IR) spectroscopy, UV-vis spectroscopy and mass spectrometry can also be used for ligand detection on a surface. These techniques can detect characteristic signals from components of a ligand and the material to which it is attached to, e.g., the elemental composition, functional groups, and parent ions or fractions thereof produced by ionization. These techniques are often unable to distinguish components of the attached ligand from similar components on the surface (e.g., peptide amides on an amide-containing surface), which may make some techniques of limited use in some situations. Unlike resonance methods, they are not restricted to specialized surfaces. For example, both XPS and IR spectroscopy have been used to characterize electrospun fibers [360].

The XPS technique measures atomic composition of surfaces, by analysing photoelectrons that are emitted when the sample is irradiated with (usually monochromatic) $\mathrm{X}$-rays. The kinetic energies of the photoelectrons are characteristic for different elements and can also be used to discern certain functional groups via curve fitting of highresolution spectra (particularly of the $C 1$ s signal). Ultra high vacuum conditions are required, and typically photoelectrons are collected from the top 6-10 nm of a surface. Detection limits and precision can vary between the different elements, but are generally between $0.5 \%$ of atomic composition (for elements detected with low sensitivity, such as nitrogen) down to $0.05 \%$ for elements with more intense photoelectron peaks (e.g., many metals).

The signal from nitrogen may be used to detect the presence of protein and peptide ligands [11,361], although in practice this approach can be problematic; signals from nitrogen atoms are relatively weak, and it is often (but not always [254]) impossible to distinguish the signal from other forms of nitrogen present on the surface. Alternatively, other elements such as fluorine can be introduced into the molecules of interest. Fluorinecontaining molecules are highly suitable for derivatization XPS because firstly, fluorine is an element not commonly present on many surfaces, and secondly, the F 1s molecular orbital has a high photoionization cross-section, thus improving the sensitivity of XPS. This method may be particularly useful in cases where small ligands (with a high percentage of fluorine) are conjugated at high densities, but requires a modified ligand to introduce the fluorine [32]. Converting atomic abundance to an areal density is not generally attempted, however, with the use of several assumptions and modeling, atomic percentage of an element can be converted into surface density, with resolution down to tens of $\mathrm{pmol} / \mathrm{cm}^{2}$ [32].

IR spectroscopy can also be applied to the problem in a similar way to XPS, although to our knowledge it has only been used to detect (not quantify) ligand attachment $[157,254,255]$. The technique is sensitive to functional groups such as amides, which are present in proteins and peptides on a surface. It has relatively deep surface penetration compared to XPS $[43,360]$, which limits its usefulness. However the equipment is less expensive than XPS, and unlike XPS does not require the use of ultra high vacuum (UHV). This makes it a potentially useful method for quick confirmation that ligands are present.

Tugulu et al. use UV-vis spectroscopy along with a pyrene-functionalized RGD peptide to quantify surface density [255]. This method appears to have good sensitivity (down to $0.5 \mathrm{pmol} / \mathrm{cm}^{2}$ ), but required assumptions about the extinction coefficient as well as a chemically modified ligand.

Time-of-flight secondary ion mass spectrometry (ToF SIMS) is highly surface sensitive, but difficult to use for quantifying ligand density [362]. However, its ability to map 2D patterns of ligands (in this case of an RGD peptide) has been used [230]. SIMS has also been used to investigate protein orientation at a surface (using its surface penetration of only $\sim 1 \mathrm{~nm}$ ) $[363,364]$, as well as the surface composition of complex ECM protein mixtures $[365,366]$. Complex mass spectra of protein-modified surfaces can be analyzed using Principle Component Analysis [243].

\subsubsection{Ligand specific methods for unmodified (label-free) ligands}

These methods can distinguish between different ligands, and do not require special modification of the ligand prior to attachment.

Enzyme-linked immunosorbent assays (ELISAs) can detect a specific ligand without using any pre-modification, using antibodies to that ligand. The sensitivity of the assay is dependent on the activity of the antibodies; very high sensitivity down to $0.1 \mathrm{ng} / \mathrm{cm}^{2}$ has been reported [52], although typical resolution is not this good. This technique is commonly used with growth factors, as many kits and antibodies are commonly available. In addition, antibodies against RGD [7], larger ECM proteins [269], fluorescein [367] and His6 [269] have all been used for quantification of ligand density. ELISAs can be sensitive to ligand conformation [358], and may be of increased usefulness when the antibody-binding site and the receptor-binding site are the same.

ELISAs are commonly used to examine ligands in solution, and simple indirect protocols that compare the 
concentration of a ligand solution before and after conjugation can be used to infer surface density [368]. However, as with colorimetric tests, indirect testing can be inaccurate. Improved methods include applying antibody solutions directly to a solid substrate $[48,49,52,369]$, or digesting a hydrogel substrate and analysing the resulting solution [176]. Some protocols may require an assumption that surface-bound enzymes have identical activity to those in solution, which may reduce the reliability of ELISAs for accurate quantification [99]. If no appropriate antibodies are available for detection, proteins can also be expressed to include further functional sections for detection via ELISA [370].

Soluble receptor proteins, instead of antibodies, can be used in a similar way. This can directly confirm the ability of receptors to bind and probe the affinity of the substratebound ligand for the receptor. While this is unique among the techniques discussed here, it still does not confirm the ability to induce downstream signals - that is, whether the ligand is acting as a full agonist, partial agonist or antagonist. As with ELISA, binding of the receptors to the substrate requires a further detection step, for example using SPR [33] or fluorescence [371].

Both of these techniques may be able to give some indication of the bioactivity of the attached ligand, as binding of the antibody/receptor is dependent on conformation. However this may also be a drawback; binding in this case is therefore dependent on two factors, density and affinity/bioactivity. Potentially the techniques discussed here could be combined with conformation-independent techniques (e.g., as discussed in the preceding or following sections) to separate these effects, and at the same time create a measure of binding and activity for the immobilized ligand.

Peptide digestion using acid solutions can also be used for detection of protein and peptide ligands provided the surface area and ligand concentration assessed are sufficiently high [372-374]. The immobilized ligands are digested along with the gel substrate, and the type and quantity of various amino acids are then detected using high performance liquid chromatography (HPLC). This technique can confirm the amino acid makeup of the attached protein or peptide, giving some level of specificity, but at the same time uses a general protocol that in principle does not require modification for other amino acid-based ligands.

\subsubsection{Ligand specific methods using modified ligands}

This section describes the use of ligands that are labeled with tags for quantification prior to conjugation to the substrate. Labeling may be particularly appropriate for peptide ligands, as their small size can make them difficult to detect using label-free methods.

Use of radioactive ligands for density quantification has been the gold standard for many years due to the high accuracy and high sensitivity $\left(\mathrm{fmol} / \mathrm{cm}^{2}\right)$ of the techniques [375]. Peptides or proteins are generally radioiodinated $\left(\mathrm{I}_{125}\right)$ via a tyrosine residue $[103,151,237,258]$. Radioiodinated ligands are generally diluted with unmodified versions, and the assumption is made that the two couple to the surface in an identical fashion. Gradient patterning may be examined by taking sections of substrate and reading these individually [376]. Alternatively, Chollet et al. used ${ }^{3} \mathrm{H}$-labeled lysine to quantify density using a micro-imager with reported spatial resolution of $15 \mu \mathrm{m}$ [377], while Clémence et al. were able to visualize $20 \mu \mathrm{m}$ stripes of a ${ }^{14}$ C-labeled YIGSR peptide [378]. Techniques using radiolabeling have good accuracy and precision, but require specialized equipment. This, along with the involved safety protocols for working with radiation in most countries, prevents this technique from becoming standard.

Fluorescent ligands are of particular use in visualizing spatial distributions of ligands. Ligand distribution in many 3D structures can be examined using confocal microscopy, with spatial resolution down to $1 \mu \mathrm{m}$. Quenching from interactions of the fluorescent tag with a substrate can be a problem however, and quantification data from fluorescent tags on a surface may be only semi-quantitative [379].

Cleavable fluorescent tags offer one way around the surface-quenching problem, and have been developed as a high-sensitivity alternative to radiolabeling. One method uses an enzymatically-cleavable fluorescein to avoid quenching effects [101,379]. This method is easy to perform and can detect peptide density down to at least $1 \mathrm{pmol} / \mathrm{cm}^{2}$, but requires an enzymatically cleavable sequence to be included within the peptide during manufacture. Coad et al. describe an alternative fluorescence method utilizing europium-tagged proteins [357]. A commercial kit was used to label human serum albumin with an isocyanated europium chelate. This technique is simple, can be performed on protein or peptide ligands post-translation or post-synthesis, and has high sensitivity (down to femtomolar limits of detection).

As discussed in Section 5.1.1, ligands can also be modified so that they can be detected via spectroscopic analyses like XPS and UV-vis spectroscopy. Other potential methods could be the immobilization of ligands via a stimulusresponsive linker (see Section 4.4) or a degradable bond (e.g., disulfide bonds, see Section 3.2.4; or His6-Ni-NTA complexes, Section 3.3.3). However, to date we are not aware of these techniques being used for quantification of ligand density.

\subsection{Ligand bioactivity}

Quantifying the bioactivity of ligands is in general far more difficult than quantifying their density, and detailed characterization is often neglected. In principle, the bioactivity of the attached ligand can be demonstrated by the growth of cells on the modified substrate, and the presence of a change compared to an unmodified control. While this is a standard approach, it does not give any indication as to whether full or only partial biofunctionality has been retained. It is also impossible to determine whether all attached ligands are equally biofunctional, whether receptor activation is already saturated, or whether bioactivity of the ligand is modified by presentation on a surface (see Section 2.2). Similarly, comparisons between soluble ligands and attached ligands to investigate biofunctionality, while common [43], should be interpreted with caution.

Another common method is to modify the ligand with a spacer prior to attachment on the substrate, and then to 
compare the bioactivity (in solution) of the modified and unmodified ligands [201]. This method will confirm that the spacer itself does not interfere with receptor binding. However, interactions between the ligand and the surface may still affect bioactivity once the ligand is attached.

An advanced fluorescence technique, Förster resonance energy transfer (FRET), can be used to examine distance changes between two fluorescent probes. It has been used to examine the binding strength between receptors and integrin binding peptides [118], folding of proteins that are attached to surfaces $[55,56]$, and also to investigate the strength of affinity interactions used to immobilize ligands [165].

Direct evidence for receptor-ligand binding and subsequent activation can be obtained by investigating the activation of signaling pathways. Markers are chosen depending on the receptor being targeted. Assembly of focal adhesions is now a common marker in studies of integrin-active surfaces, although these do not specify which particular integrin receptors are activated. Examining the phosphorylation of targeted receptors [52] or proteins further downstream [109] via western blotting is a method that can be widely applied. These experiments provide valuable quantitative information, both as an output measure of stimulation and as an input variable for looking at downstream cellular behavior (spreading, proliferation, differentiation, etc.). However, they may be cell-type specific; currently there is no standard for measuring the bioactivity of a ligand independently of cell type.

\subsection{Quantification conclusions}

Quantification of surface-bound ligands requires the researcher to examine both surface/bulk ligand density and bioactivity. Many techniques are available to quantify ligand density on a substrate, each of which has advantages and disadvantages in different situations. It is more difficult to measure the bioactivity of ligands, and currently this can only be done as an average of all attached ligands. Therefore more advanced conjugation methods (keeping all ligands identically presented, using oriented attachment methods and non-interacting substrates) are desirable. It is important to check downstream activation of signaling cascades (e.g., receptor phosphorylation and protein expression) rather than just the final biological result (spreading or differentiation), as this can provide both extra validation of receptor stimulation and a standard with which to compare bulk cell responses.

\section{Conclusions}

Ligand-modified substrates often provide an excellent platform to examine fundamental biological questions, as well as having potential applications in many sub-fields of biotechnology. However a thorough knowledge of a ligand and receptor's biology is required for optimal use, and many factors that can affect receptor-ligand activation may need to be considered. In this review we have examined techniques that have been used to attach ligands of various receptors to polymer or polymer-coated substrates, as well as techniques used in related fields that could be adapted. We have detailed the advantages and disadvantages of various methods in a way that is broadly applicable, rather than as a collection of isolated cases.

When using substrate-bound ligands, activation of cellular receptors is affected by both the intrinsic bioactivity of a given ligand for that receptor, and modulatory factors arising from the conjugation and surrounding environment. Because of this, new conjugation methods are constantly being devised that offer increased ease of use, consistency of immobilization and other advantages over those previously used. Accurate characterization of substrates also requires an appropriate choice of method, and methods are constantly being developed and improved to perform this characterization.

The advanced techniques detailed in this review offer many advantages over simpler protocols. At the same time, many applications will require only simpler systems non-optimal use can be "good enough" for many studies. We hope this review has provided an overview of both the techniques that are available for ligand conjugation in polymeric biomaterials, and the situations in which these techniques are most required.

\section{Acknowledgements}

The authors would like to thank Lisa Strover for critical reading of the manuscript. AER was supported by an Australian Postgraduate Award and by the Cooperative Research Centre for Polymers. DRN was supported by an Australian Research Council Australian Postdoctoral Fellowship and subsequently by an NHMRC Career Development Award (APP1050684).

\section{References}

[1] Ito Y. Growth factors and protein-modified surfaces and interfaces. In: Ducheyne P, Healy K, Hutmacher D, Grainger DW, Kirkpatrick CJ editors. Comprehensive biomaterials, vol. 4. Amsterdam: Elsevier Sci; 2011. p. 247-79.

[2] Carson AE, Barker TH. Emerging concepts in engineering extracellular matrix variants for directing cell phenotype. Regener Med 2009;4:593-600.

[3] Humphries J, Byron A, Humphries M. Integrin ligands at a glance. J Cell Sci 2006;119:3901-3.

[4] Friedman W. Growth factors. In: Brady ST, Siegel GJ, Albers RW, Price DL, editors. Basic neurochem. 8th ed. Amsterdam: Elsevier Ltd.; 2012. p. 546-57.

[5] Masters K. Covalent growth factor immobilization strategies for tissue repair and regeneration. Macromol Biosci 2011;11:1149-63.

[6] Ito Y. Covalently immobilized biosignal molecule materials for tissue engineering. Soft Matter 2008;4:46-56.

[7] Hersel U, Dahmen C, Kessler H. RGD modified polymers: biomaterials for stimulated cell adhesion and beyond. Biomaterials 2003;24:4385-415

[8] Perlin L, MacNeil S, Rimmer S. Production and performance of biomaterials containing RGD peptides. Soft Matter 2008;4:2331-49.

[9] Zhu J. Bioactive modification of poly(ethylene glycol) hydrogels for tissue engineering. Biomaterials 2010;31:4639-56.

[10] Green R, Lovell N, Poole-Warren L. Cell attachment functionality of bioactive conducting polymers for neural interfaces. Biomaterials 2009;30:3637-44.

[11] Santiago LY, Nowak RW, Peter Rubin J, Marra KG. Peptidesurface modification of poly(caprolactone) with laminin-derived sequences for adipose-derived stem cell applications. Biomaterials 2006;27:2962-9.

[12] Yamada Y, Katagiri F, Hozumi K, Kikkawa Y, Nomizu M. Cell behavior on protein matrices containing laminin $\alpha 1$ peptide AG73. Biomaterials 2011;32:4327-35. 
[13] Kubinová S, Horák D, Kozubenko N, Vanecek V, Proks V, Price J, Cocks G, Syková E. The use of superporous Ac-CGGASIKVAVS$\mathrm{OH}$-modified PHEMA scaffolds to promote cell adhesion and the differentiation of human fetal neural precursors. Biomaterials 2010;31:5966-75.

[14] Silva G, Czeisler C, Niece K, Beniash E, Harrington D, Kessler J, Stupp S. Selective differentiation of neural progenitor cells by highepitope density nanofibers. Science 2004;303:1352-5

[15] Skaper S. The biology of neurotrophins, signalling pathways, and functional peptide mimetics of neurotrophins and their receptors. CNS Neurol Disord Drug Targets 2008;7:46-62.

[16] Lee JY, Choo JE, Choi YS, Suh JS, Lee SJ, Chung CP, Park YJ. Osteoblastic differentiation of human bone marrow stromal cells in self-assembled BMP-2 receptor-binding peptide-amphiphiles. Biomaterials 2009;30:3532-41.

[17] Chen H, Yuan L, Song W, Wu Z, Li D. Biocompatible polymer materials: role of protein-surface interactions. Prog Polym Sci 2008;33:1059-87.

[18] Jongpaiboonkit L, King W, Murphy W. Screening for 3D environments that support human mesenchymal stem cell viability using hydrogel arrays. Tissue Eng Part A 2009;15:343-53.

[19] Barker TH. The role of ECM proteins and protein fragments in guiding cell behavior in regenerative medicine. Biomaterials 2011;32:4211-4

[20] Collier JH, Segura T. Evolving the use of peptides as components of biomaterials. Biomaterials 2011;32:4198-204.

[21] Hynes R. The extracellular matrix: not just pretty fibrils. Science 2009;326:1216-9.

[22] Petrie T, Capadona J, Reyes C, García A. Integrin specificity and enhanced cellular activities associated with surfaces presenting a recombinant fibronectin fragment compared to RGD supports. Biomaterials 2006;27:5459-70.

[23] Martino M, Mochizuki M, Rothenfluh D, Rempel S, Hubbell J, Barker T. Controlling integrin specificity and stem cell differentiation in 2D and 3D environments through regulation of fibronectin domain stability. Biomaterials 2009;30:1089-97.

[24] Heckmann D, Kessler H. Design and chemical synthesis of integrin ligands. Methods Enzymol 2007;426:463-503.

[25] Harbers G, Healy K. The effect of ligand type and density on osteoblast adhesion, proliferation, and matrix mineralization. J Biomed Mater Res Part A 2005;75:855-69.

[26] Saha K, Irwin EF, Kozhukh J, Schaffer DV, Healy KE. Biomimetic interfacial interpenetrating polymer networks control neural stem cell behavior. J Biomed Mater Res Part A 2007;81:240-9.

[27] Khew S, Zhu X, Tong Y. An integrin-specific collagen-mimetic peptide approach for optimizing Hep3B liver cell adhesion, proliferation, and cellular functions. Tissue Eng 2007;13:2451-63.

[28] Koivunen E, Wang B, Ruoslahti E. Phage libraries displaying cyclic peptides with different ring sizes: ligand specificities of the RGDDirected Integrins. Nat Biotechnol 1995;13:265-70.

[29] Hsiong S, Boontheekul T, Huebsch N, Mooney D. Cyclic arginine-glycine-aspartate peptides enhance three-dimensional stem cell osteogenic differentiation. Tissue Eng Part A 2009; $15: 263-72$.

[30] Haubner R, Gratias R, Diefenbach B, Goodman SL, Jonczyk A, Kessler H. Structural and functional aspects of RGD-containing cyclic pentapeptides as highly potent and selective integrin $\alpha \mathrm{V} \beta 3$ antagonists. J Am Chem Soc 1996;118:7461-72.

[31] Assa-Munt N, Jia X, Laakkonen P, Ruoslahti E. Solution structures and integrin binding activities of an RGD peptide with two isomers. Biochemistry 2001;40:2373-8.

[32] Biltresse S, Attolini M, Marchand-Brynaert J. Cell adhesive PET membranes by surface grafting of RGD peptidomimetics. Biomaterials 2005;26:4576-87.

[33] Klim JR, Fowler AJ, Courtney AH, Wrighton PJ, Sheridan RTC, Wong ML, Kiessling LL. Small-molecule-modified surfaces engage cells through the $\alpha v \beta 3$ integrin. ACS Chem Biol 2012;7: 518-25.

[34] Rerat V, Dive G, Cordi Aa, Tucker GC, Bareille R, Amédée J, Bordenave L, Marchand-Brynaert J. alphavbeta3 Integrin-targeting Arg-Gly-Asp (RGD) peptidomimetics containing oligoethylene glycol (OEG) spacers. J Med Chem 2009;52:7029-43.

[35] Dahmen C, Auernheimer J, Meyer A, Enderle A, Goodman S, Kessler H. Improving implant materials by coating with nonpeptidic, highly specific integrin ligands. Angew Chem Int Ed 2004;43: 6649-52.

[36] Rechenmacher F, Neubauer S, Polleux J, Mas-Moruno C, De Simone M, Cavalcanti-Adam E, Spatz J, Fässler R, Kessler H. Functionalizing $\alpha v \beta 3$ - or $\alpha 5 \beta 1$-selective integrin antagonists for surface coating: a method to discriminate integrin subtypes in vitro. Angew Chem Int Ed 2013;52:1572-5

[37] Nakaji-Hirabayashi T, Kato K, Iwata H. Essential role of structural integrity and firm attachment of surface-anchored epidermal growth factor in adherent culture of neural stem cells. Biomaterials 2008;29:4403-8.

[38] Boucher C, Liberelle B, Jolicoeur M, Durocher Y, De Crescenzo G. Epidermal growth factor tethered through coiled-coil interactions induces cell surface receptor phosphorylation. Bioconjugate Chem 2009;20:1569-77.

[39] Keselowsky B, Collard D, García A. Surface chemistry modulates focal adhesion composition and signaling through changes in integrin binding. Biomaterials 2004;25:5947-54.

[40] Keselowsky B, Collard D, García A. Integrin binding specificity regulates biomaterial surface chemistry effects on cell differentiation. Proc Natl Acad Sci U S A 2005;102:5953-7.

[41] Kohen N, Little L, Healy K. Characterization of Matrigel interfaces during defined human embryonic stem cell culture. Biointerphases 2009;4:69-79.

[42] Salinas C, Anseth K. The influence of the RGD peptide motif and its contextual presentation in PEG gels on human mesenchymal stem cell viability. J Tissue Eng Regen Med 2008;2:296-304.

[43] Goddard J, Hotchkiss JH. Polymer surface modification for the attachment of bioactive compounds. Prog Polym Sci 2007;32:698-725.

[44] Beer J, Springer K, Coller B. Immobilized Arg-Gly-Asp (RGD) peptides of varying lengths as structural probes of the platelet glycoprotein IIb/IIIa receptor. Blood 1992;79:117-28.

[45] Pallarola D, Bochen A, Boehm H, Rechenmacher F, Sobahi TR, Spatz JP, Kessler H. Interface immobilization chemistry of cRGD-based peptides regulates integrin mediated cell adhesion. Adv Funct Mater 2013, http://dx.doi.org/10.1002/adfm.201302411.

[46] Fan VH, Tamama K, Au A, Littrell R, Richardson LB, Wright JW, Wells A, Griffith LG. Tethered epidermal growth factor provides a survival advantage to mesenchymal stem cells. Stem Cells 2007;25:1241-51.

[47] Mann BK, Schmedlen RH, West JL. Tethered-TGF-beta increases extracellular matrix production of vascular smooth muscle cells. Biomaterials 2001:22:439-44

[48] Horne MK, Nisbet DR, Forsythe JS, Parish C. Three dimensional nanofibrous scaffolds incorporating immobilized BDNF promote proliferation and differentiation of cortical neural stem cells. Stem Cells Dev 2009;19:843-52.

[49] Wang TY, Forsythe JS, Nisbet DR, Parish CL. Promoting engraftment of transplanted neural stem cells/progenitors using biofunctionalised electrospun scaffolds. Biomaterials 2012;33:9188-97.

[50] Zhang YZ, Moheban DB, Conway BR, Bhattacharyya A, Segal RA. Cell surface Trk receptors mediate NGF-induced survival while internalized receptors regulate NGF-induced differentiation. J Neurosci 2000;20:5671-8.

[51] MacInnis BL, Campenot RB. Retrograde support of neuronal survival without retrograde transport of nerve growth factor. Science 2002;295:1536-9.

[52] Anderson S, Chen T, Iruela-Arispe M, Segura T. The phosphorylation of vascular endothelial growth factor receptor-2 (VEGFR-2) by engineered surfaces with electrostatically or covalently immobilized VEGF. Biomaterials 2009;30:4618-28.

[53] Anderson S, Shergill B, Barry Z, Manousiouthakis E, Chen T, Botvinick E, Platt M, Iruela-Arispe M, Segura T. VEGF internalization is not required for VEGFR-2 phosphorylation in bioengineered surfaces with covalently linked VEGF. Integr Biol 2011;3:887-96.

[54] Zheng J, Shen WH, Lu TJ, Zhou Y, Chen Q, Wang Z, Xiang T, Zhu YC, Zhang C, Duan S, Xiong ZQ. Clathrin-dependent endocytosis is required for TrkB-dependent Akt-mediated neuronal protection and dendritic growth. J Biol Chem 2008;283:13280-8.

[55] Amirgoulova EV, Groll J, Heyes CD, Ameringer T, Röcker C, Möller M, Nienhaus GU. Biofunctionalized polymer surfaces exhibiting minimal interaction towards immobilized proteins. ChemPhysChem 2004:5:552-5.

[56] Groll J, Amirgoulova EV, Ameringer T, Heyes CD, Röcker C, Nienhaus GU, Möller M. Biofunctionalized, ultrathin coatings of cross-linked star-shaped poly(ethylene oxide) allow reversible folding of immobilized proteins. J Am Chem Soc 2004;126:4234-9.

[57] Liu Q, Singh A, Lalani R, Liu L. Ultralow fouling polyacrylamide on gold surfaces via surface-initiated atom transfer radical polymerization. Biomacromolecules 2012;13:1086-92.

[58] Wavhal DS, Fisher ER. Membrane surface modification by plasmainduced polymerization of acrylamide for improved surface properties and reduced protein fouling. Langmuir 2003;19:79-85. 
[59] Gunkel G, Weinhart M, Becherer T, Haag R, Huck W. Effect of polymer brush architecture on antibiofouling properties. Biomacromolecules 2011;12:4169-72.

[60] Rodriguez-Emmenegger C, Brynda E, Riedel T, Houska M, Subr V, Alles A, Hasan E, Gautrot J, Huck W. Polymer brushes showing non-fouling in blood plasma challenge the currently accepted design of protein resistant surfaces. Macromol Rapid Commun 2011;32:952-7

[61] Zhao C, Li L, Zheng J. Achieving highly effective nonfouling performance for surface-grafted poly(HPMA) via atom-transfer radical polymerization. Langmuir 2010;26:17375-82.

[62] Telford A, James M, Meagher L, Neto C. Thermally cross-linked PNVP films as antifouling coatings for biomedical applications. ACS Appl Mater Interfaces 2010;2:2399-408.

[63] Jiang S, Cao Z. Ultralow-fouling, functionalizable, and hydrolyzable zwitterionic materials and their derivatives for biological applications. Adv Mater 2010;22:920-32.

[64] Zhang L, Cao Z, Bai T, Carr L, Ella-Menye JR, Irvin C, Ratner B, Jiang S. Zwitterionic hydrogels implanted in mice resist the foreign-body reaction. Nat Biotechnol 2013;31:553-6.

[65] Krause JE, Brault ND, Li Y, Xue H, Zhou Y, Jiang S. Photoinifertermediated polymerization of zwitterionic carboxybetaine monomers for low-fouling and functionalizable surface coatings. Macromolecules 2011;44:9213-20.

[66] Massia S, Holecko M, Ehteshami G. In vitro assessment of bioactive coatings for neural implant applications. J Biomed Mater Res Part A 2004;68:177-86.

[67] Doran M, Frith J, Prowse A, Fitzpatrick J, Wolvetang E, Munro T, Gray P, Cooper-White J. Defined high protein content surfaces for stem cell culture. Biomaterials 2010;31:5137-42.

[68] Khademhosseini A, Suh K, Yang J, Eng G, Yeh J, Levenberg S, Langer R. Layer-by-layer deposition of hyaluronic acid and poly-L-lysine for patterned cell co-cultures. Biomaterials 2004;25:3583-92.

[69] Stabenfeldt S, Munglani G, García A, LaPlaca M. Biomimetic microenvironment modulates neural stem cell survival, migration, and differentiation. Tissue Eng Part A 2010;16:3747-58.

[70] Meyers S, Grinstaff M. Biocompatible and bioactive surface modifications for prolonged in vivo efficacy. Chem Rev 2012;112:1615-32.

[71] DeForest CA, Anseth KS. Cytocompatible click-based hydrogels with dynamically tunable properties through orthogona photoconjugation and photocleavage reactions. Nat Chem 2011:3:925-31.

[72] Hucknall A, Rangarajan S, Chilkoti A. In pursuit of zero: polymer brushes that resist the adsorption of proteins. Adv Mater 2009;21:2441-6.

[73] Strulson M, Johnson D, Maurer J. Increased stability of glycolterminated self-assembled monolayers for long-term patterned cell culture. Langmuir 2012;28:4318-24.

[74] Xu FJ, Neoh KG, Kang ET. Bioactive surfaces and biomaterials via atom transfer radical polymerization. Prog Polym Sci 2009;34:719-61.

[75] Barbey R, Lavanant L, Paripovic D, Schüwer N, Sugnaux C, Tugulu S, Klok HA. Polymer brushes via surface-initiated controlled radical polymerization: synthesis, characterization, properties, and applications. Chem Rev 2009;109:5437-527.

[76] Siegwart DJ, Oh JK, Matyjaszewski K. ATRP in the design of functional materials for biomedical applications. Prog Polym Sci 2012;37:18-37

[77] Ma H, Wells M, Beebe TP, Chilkoti A. Surface-initiated atom transfer radical polymerization of oligo(ethylene glycol) methyl methacrylate from a mixed self-assembled monolayer on gold. Adv Funct Mater 2006;16:640-8.

[78] Kuang J, Messersmith P. Universal surface-initiated polymerization of antifouling zwitterionic brushes using a mussel-mimetic peptide initiator. Langmuir 2012;28:7258-66.

[79] Edmondson S, Armes SP. Synthesis of surface-initiated polymer brushes using macro-initiators. Polym Int 2009;58:307-16.

[80] Strover LT, Malmström J, Laita O, Reynisson J, Aydemir N, Nieuwoudt MK, Williams DE, Dunbar PR, Brimble MA, Travas-Sejdic J. A new precursor for conducting polymer-based brush interfaces with electroactivity in aqueous solution. Polymer 2013;54:1305-17.

[81] Coad B, Lu Y, Glattauer V, Meagher L. Substrate-independent method for growing and modulating the density of polymer brushes from surfaces by ATRP. ACS Appl Mater Interfaces 2012;4:2811-23.

[82] Tsang K, Hou X, Coad B, Forsythe JS, Meagher L, Thissen $\mathrm{H}$, Ameringer T, Evans R, Pasic P. Polymer coatings. Int Pat Wo/2010/020008; 2010.
[83] Wörz A, Berchtold B, Moosmann K, Prucker O, Rühe J. Proteinresistant polymer surfaces. J Mater Chem 2012;22:19547-61.

[84] Latour R. Thermodynamic perspectives on the molecular mechanisms providing protein adsorption resistance that include protein-surface interactions. J Biomed Mater Res Part A 2006;78:843-54

[85] Muir B, Tarasova A, Gengenbach T, Menzies D, Meagher L, Rovere F, Fairbrother A, McLean K, Hartley P. Characterization of lowfouling ethylene glycol containing plasma polymer films. Langmuir 2008;24:3828-35.

[86] Tugulu S, Klok HA. Stability and nonfouling properties of poly(poly(ethylene glycol) methacrylate) brushes under cell culture conditions. Biomacromolecules 2008;9:906-12.

[87] Herold DA, Keil K, Bruns DE. Oxidation of polyethylene glycols by alcohol dehydrogenase. Biochem Pharmacol 1989;38:73-6.

[88] Roosjen A, de Vries J, van der Mei H, Norde W, Busscher H. Stability and effectiveness against bacterial adhesion of poly(ethylene oxide) coatings in biological fluids. J Biomed Mater Res Part A 2005;73:347-54

[89] Ladd J, Zhang Z, Chen S, Hower J, Jiang S. Zwitterionic polymers exhibiting high resistance to nonspecific protein adsorption from human serum and plasma. Biomacromolecules 2008;9:1357-61.

[90] Chen S, Li L, Zhao C, Zheng J. Surface hydration: principles and applications toward low-fouling/nonfouling biomaterials. Polymer 2010;51:5283-93

[91] Yu Q, Zhang Y, Wang H, Brash J, Chen H. Anti-fouling bioactive surfaces. Acta Biomater 2011;7:1550-7.

[92] Halperin A, Kröger M. Ternary protein adsorption onto brushes: strong versus weak. Langmuir 2009;25:11621-34.

[93] Nakajima M, Ishimuro T, Kato K, Ko IK, Hirata I, Arima Y, Iwata H. Combinatorial protein display for the cell-based screening of biomaterials that direct neural stem cell differentiation. Biomaterials 2007;28:1048-60.

[94] Soen Y, Mori A, Palmer T, Brown P. Exploring the regulation of human neural precursor cell differentiation using arrays of signaling microenvironments. Mol Syst Biol 2006;2, 37/1-14.

[95] Raynor J, Capadona J, Collard D, Petrie T, García A. Polymer brushes and self-assembled monolayers: versatile platforms to control cell adhesion to biomaterials (review). Biointerphases 2009;4:FA3-16

[96] Hayashi T, Hara M. Nonfouling self-assembled monolayers: mechanisms underlying protein and cell resistance. Curr Phys Chem 2011;1:90-8.

[97] Ostuni E, Chapman RG, Liang MN, Meluleni G, Pier G, Ingber DE Whitesides GM. Self-assembled monolayers that resist the adsorption of proteins and the adhesion of bacterial and mammalian cells. Langmuir 2001;17:6336-43.

[98] Li L, Chen S, Zheng J, Ratner B, Jiang S. Protein adsorption on oligo(ethylene glycol)-terminated alkanethiolate self-assembled monolayers: the molecular basis for nonfouling behavior. J Phys Chem B 2005;109:2934-41.

[99] Vermette P, Gengenbach T, Divisekera U, Kambouris PA, Griesse HJ, Meagher L. Immobilization and surface characterization of NeutrAvidin biotin-binding protein on different hydrogel interlayers. J Colloid Interface Sci 2003;259:13-26.

[100] Ayres N. Polymer brushes: applications in biomaterials and nanotechnology. Polym Chem 2010;1:769-77.

[101] Little L, Dane K, Daugherty P, Healy K, Schaffer D. Exploiting bacterial peptide display technology to engineer biomaterials for neural stem cell culture. Biomaterials 2011;32:1484-94.

[102] Saha K, Keung AJ, Irwin EF, Li Y, Little LE, Schaffer DV, Healy KE Substrate modulus directs neural stem cell behavior. Biophys 2008:95:4426-38.

[103] Berg M, Yang S, Hammond P, Rubner M. Controlling mammalian cell interactions on patterned polyelectrolyte multilayer surfaces. Langmuir 2004;20:1362-8.

[104] Ameringer T, Fransen P, Bean P, Johnson G, Pereira S, Evans RA Thissen $\mathrm{H}$, Meagher L. Polymer coatings that display specific biological signals while preventing nonspecific interactions. J Biomed Mater Res Part A 2012:100:370-9.

[105] Ruiz A, Buzanska L, Gilliland D, Rauscher H, Sirghi L, Sobanski T, Zychowicz M, Ceriotti L, Bretagnol F, Coecke S, Colpo P, Rossi F. Micro-stamped surfaces for the patterned growth of neural stem cells. Biomaterials 2008;29:4766-74

[106] Ananthanarayanan B, Little L, Schaffer D, Healy K, Tirrell M. Neural stem cell adhesion and proliferation on phospholipid bilayers functionalized with RGD peptides. Biomaterials 2010;31:8706-15.

[107] Thid D, Holm K, Eriksson P, Ekeroth J, Kasemo B, Gold J. Supported phospholipid bilayers as a platform for neural progenitor cell culture. J Biomed Mater Res Part A 2008;84:940-53. 
[108] Cameron AR, Frith JE, Cooper-White JJ. The influence of substrate creep on mesenchymal stem cell behaviour and phenotype. Biomaterials 2011;32:5979-93.

[109] Trappmann B, Gautrot JE, Connelly JT, Strange DGT, Li Y, Oyen ML, Cohen Stuart MA, Boehm H, Li B, Vogel V, Spatz JP, Watt FM, Huck WTS. Extracellular-matrix tethering regulates stem-cell fate. Nat Mater 2012;11:642-9.

[110] Lo CM, Wang HB, Dembo M, Wang YL. Cell movement is guided by the rigidity of the substrate. Biophys J 2000;79:144-52.

[111] Pelham R, Wang Y. Cell locomotion and focal adhesions are regulated by substrate flexibility. Proc Natl Acad Sci U S A 1997;94:13661-5.

[112] Engler AJ, Sen S, Sweeney HL, Discher DE. Matrix elasticity directs stem cell lineage specification. Cell 2006;126:677-89.

[113] Leipzig ND, Shoichet MS. The effect of substrate stiffness on adult neural stem cell behavior. Biomaterials 2009:30:6867-78

[114] Geiger B, Spatz J, Bershadsky A. Environmental sensing through focal adhesions. Nat Rev Mol Cell Biol 2009;10:21-33.

[115] Discher D, Janmey P, Wang YL. Tissue cells feel and respond to the stiffness of their substrate. Science 2005;310:1139-43.

[116] Keung A, Healy K, Kumar S, Schaffer D. Biophysics and dynamics of natural and engineered stem cell microenvironments. Wiley Interdiscip Rev Syst Biol Med 2010;2:49-64.

[117] Trappmann B, Chen CS. How cells sense extracellular matrix stiffness: a material's perspective. Curr Opin Biotechnol 2013;24: $948-53$.

[118] Huebsch N, Arany PR, Mao AS, Shvartsman D, Ali OA, Bencherif SA, Rivera-Feliciano J, Mooney DJ. Harnessing traction-mediated manipulation of the cell/matrix interface to control stem-cell fate. Nat Mater 2010;9:518-26.

[119] Keung A, de Juan-Pardo E, Schaffer D, Kumar S. Rho GTPases mediate the mechanosensitive lineage commitment of neural stem cells. Stem Cells 2011;29:1886-97.

[120] Grashoff C, Hoffman BD, Brenner MD, Zhou R, Parsons M, Yang MT, McLean MA, Sligar SG, Chen CB, Ha T, Schwartz MA. Measuring mechanical tension across vinculin reveals regulation of focal adhesion dynamics. Nature 2010:466:263-6.

[121] Discher D, Mooney D, Zandstra P. Growth factors, matrices, and forces combine and control stem cells. Science 2009;324: 1673-7.

[122] Keung A, Kumar S, Schaffer D. Presentation counts: microenvironmental regulation of stem cells by biophysical and material cues. Ann Rev Cell Dev Biol 2010;26:533-56.

[123] Marklein R, Burdick J. Controlling stem cell fate with material design. Adv Mater 2010:22:175-89.

[124] Algar W, Prasuhn D, Stewart M, Jennings T, Blanco-Canosa J, Dawson P, Medintz I. The controlled display of biomolecules on nanoparticles: a challenge suited to bioorthogonal chemistry. Bioconjugate Chem 2011;22:825-58.

[125] Rusmini F, Zhong Z, Feijen J. Protein immobilization strategies for protein biochips. Biomacromolecules 2007:8:1775-89.

[126] Hughes CS, Postovit LM, Lajoie GA, Matrigel:. A complex protein mixture required for optimal growth of cell culture. Proteomics 2010;10:1886-90.

[127] Hughes C, Radan L, Betts D, Postovit L, Lajoie G. Proteomic analysis of extracellular matrices used in stem cell culture. Proteomics 2011;11:3983-91

[128] Yang F, Cho SW, Son S, Hudson S, Bogatyrev S, Keung L, Kohane $\mathrm{D}$, Langer R, Anderson D. Combinatorial extracellular matrices for human embryonic stem cell differentiation in 3D. Biomacromolecules 2010;11:1909-14.

[129] Lee J, Yu HS, Lee GS, Ji A, Hyun J, Kim HW. Collagen gel threedimensional matrices combined with adhesive proteins stimulate neuronal differentiation of mesenchymal stem cells. J R Soc Interface 2011;8:998-1010

[130] Matson J, Zha R, Stupp S. Peptide self-assembly for crafting functional biological materials. Curr Opin Solid State Mater Sci 2011;15: 225-35.

[131] Nisbet D, Williams R. Self-assembled peptides: characterisation and in vivo response. Biointerphases 2012;7, 2/1-14.

[132] Guler M, Hsu L, Soukasene S, Harrington D, Hulvat J, Stupp S. Presentation of RGDS epitopes on self-assembled nanofibers of branched peptide amphiphiles. Biomacromolecules 2006;7:1855-63.

[133] Storrie H, Guler M, Abu-Amara S, Volberg T, Rao M, Geiger B, Stupp S. Supramolecular crafting of cell adhesion. Biomaterials 2007;28:4608-18.

[134] Zhou M, Smith A, Das A, Hodson N, Collins R, Ulijn R, Gough J. Self-assembled peptide-based hydrogels as scaffolds for anchorage-dependent cells. Biomaterials 2009;30:2523-30.
[135] Rodriguez AL, Parish CL, Nisbet DR, Williams RJ. Tuning the amino acid sequence of minimalist peptides to present biological signals via charge neutralised self assembly. Soft Matter 2013;9: 3915-9.

[136] Gelain F, Bottai D, Vescovi A, Zhang S. Designer self-assembling peptide nanofiber scaffolds for adult mouse neural stem cell 3dimensional cultures. PLoS ONE 2006;1(e119):1-11

[137] Cunha C, Panseri S, Villa O, Silva D, Gelain F. 3D culture of adult mouse neural stem cells within functionalized self-assembling peptide scaffolds. Int J Nanomed 2011;6:943-55.

[138] Lampe K, Heilshorn S. Building stem cell niches from the molecule up through engineered peptide materials. Neurosci Lett 2012:519:138-46.

[139] DiMarco R, Heilshorn S. Multifunctional materials through modular protein engineering. Adv Mater 2012;24:3923-40.

[140] Foo CWP, Lee J, Mulyasasmita W, Parisi-Amon A, Heilshorn S. Two-component protein-engineered physical hydrogels for cell encapsulation. Proc Natl Acad Sci U S A 2009;106: 22067-72.

[141] Flaim C, Chien S, Bhatia S. An extracellular matrix microarray for probing cellular differentiation. Nat Methods 2005;2:119-25.

[142] Michael KE, Vernekar VN, Keselowsky BG, Meredith JC, Latour RA, García AJ. Adsorption-induced conformational changes in fibronectin due to interactions with well-defined surface chemistries. Langmuir 2003;19:8033-40.

143] Gunawan R, King J, Lee B, Messersmith P, Miller W. Surface presentation of bioactive ligands in a nonadhesive background using DOPA-tethered biotinylated poly(ethylene glycol). Langmuir 2007:23:10635-43.

[144] Lee H, Rho J, Messersmith P. Facile conjugation of biomolecules onto surfaces via mussel adhesive protein inspired coatings. Adv Mater 2009;21:431-4.

[145] Saxer S, Portmann C, Tosatti S, Gademann K, Zürcher S, Textor M. Surface assembly of catechol-functionalized poly(L-lysine)-graftpoly(ethylene glycol) copolymer on titanium exploiting combined electrostatically driven self-organization and biomimetic strong adhesion. Macromolecules 2010;43:1050-60.

[146] Mei Y, Saha K, Bogatyrev S, Yang J, Hook A, Kalcioglu Z, Cho SW, Mitalipova M, Pyzocha N, Rojas F, Van Vliet K, Davies M, Alexander M, Langer R, Jaenisch R, Anderson D. Combinatorial development of biomaterials for clonal growth of human pluripotent stem cells. Nat Mater 2010;9:768-78

[147] Saha K, Mei Y, Reisterer C, Pyzocha N, Yang J, Muffat J, Davies M, Alexander M, Langer R, Anderson D, Jaenisch R. Surfaceengineered substrates for improved human pluripotent stem cell culture under fully defined conditions. Proc Natl Acad Sci U S A 2011;108:18714-9.

[148] Hudalla G, Murphy W. Biomaterials that regulate growth factor activity via bioinspired interactions. Adv Funct Mater 2011;21:1754-68

[149] Wang NX, von Recum HA. Affinity-based drug delivery. Macromol Biosci 2011;11:321-32

[150] McGann C, Kiick K. Heparin-functionalized materials in tissue engineering applications. In: Bhatia SK, editor. Engineering biomaterials for regenerative medicine. New York: Springer; 2012. p. $225-50$.

[151] Freudenberg U, Hermann A, Welzel P, Stirl K, Schwarz S, Grimmer M, Zieris A, Panyanuwat W, Zschoche S, Meinhold D, Storch A, Werner C. A star-PEG-heparin hydrogel platform to aid cell replacement therapies for neurodegenerative diseases. Biomaterials 2009;30:5049-60.

[152] Sakiyama-Elbert SE. Drug delivery via heparin conjugates. In: Ducheyne P, Healy K, Hutmacher D, Grainger DW, Kirkpatrick CJ, editors. Comprehensive biomaterials, vol. 4. Amsterdam: Elsevier Sci; 2011. p. 333-8.

[153] Benoit D, Durney A, Anseth K. The effect of heparin-functionalized PEG hydrogels on three-dimensional human mesenchymal stem cell osteogenic differentiation. Biomaterials 2007;28: 66-77.

[154] Nie T, Baldwin A, Yamaguchi N, Kiick K. Production of heparinfunctionalized hydrogels for the development of responsive and controlled growth factor delivery systems. J Controlled Release 2007;122:287-96.

[155] Hudalla G, Kouris N, Koepsel J, Ogle B, Murphy W. Harnessing endogenous growth factor activity modulates stem cell behavior. Integr Biol 2011;3:832-42.

[156] Hudalla G, Koepsel J, Murphy W. Surfaces that sequester serum-borne heparin amplify growth factor activity. Adv Mater 2011;23:5415-8. 
[157] Hudalla G, Murphy W. Immobilization of peptides with distinct biological activities onto stem cell culture substrates using orthogonal chemistries. Langmuir 2010;26:6449-56.

[158] Klim J, Li L, Wrighton P, Piekarczyk M, Kiessling L. A defined glycosaminoglycan-binding substratum for human pluripotent stem cells. Nat Methods 2010;7:989-94.

[159] Willerth S, Rader A, Sakiyama-Elbert S. The effect of controlled growth factor delivery on embryonic stem cell differentiation inside fibrin scaffolds. Stem Cell Res 2008;1:205-18.

[160] Sakiyama-Elbert S, Hubbell J. Development of fibrin derivatives for controlled release of heparin-binding growth factors. J Controlled Release 2000;65:389-402.

[161] Rajangam K, Behanna H, Hui M, Han X, Hulvat J, Lomasney J, Stupp S. Heparin binding nanostructures to promote growth of blood vessels. Nano Lett 2006;6:2086-90.

[162] Chow L, Wang LJ, Kaufman D, Stupp S. Self-assembling nanostructures to deliver angiogenic factors to pancreatic islets. Biomaterials 2010;31:6154-61

[163] Kanematsu A, Marui A, Yamamoto S, Ozeki M, Hirano Y, Yamamoto M, Ogawa O, Komeda M, Tabata Y. Type I collagen can function as a reservoir of basic fibroblast growth factor. J Controlled Release 2004;99:281-92.

[164] Goerges A, Nugent M. pH regulates vascular endothelial growth factor binding to fibronectin: a mechanism for control of extracellular matrix storage and release. J Biol Chem 2004;279:2307-15.

[165] Lin CC, Anseth K. Controlling affinity binding with peptidefunctionalized poly(ethylene glycol) hydrogels. Adv Funct Mater 2009;19:2325-31.

[166] McCall J, Lin CC, Anseth K. Affinity peptides protect transforming growth factor beta during encapsulation in poly(ethylene glycol) hydrogels. Biomacromolecules 2011;12:1051-7.

[167] Shah RN, Shah NA, Del Rosario Lim MM, Hsieh C, Nuber G, Stupp SI. Supramolecular design of self-assembling nanofibers for cartilage regeneration. Proc Natl Acad Sci U S A 2010;107:3293-8.

[168] Kim S, Kiick K. Heparin-mimetic sulfated peptides with modulated affinities for heparin-binding peptides and growth factors. Peptides 2007:28:2125-36

[169] Maynard H, Hubbell J. Discovery of a sulfated tetrapeptide that binds to vascular endothelial growth factor. Acta Biomater 2005;1:451-9.

[170] Christman K, Vázquez-Dorbatt V, Schopf E, Kolodziej C, Li R, Broyer R, Chen Y, Maynard H. Nanoscale growth factor patterns by immobilization on a heparin-mimicking polymer. J Am Chem Soc 2008;130:16585-91.

[171] Kolodziej C, Kim S, Broyer R, Saxer S, Decker C, Maynard H. Combination of integrin-binding peptide and growth factor promotes cell adhesion on electron-beam-fabricated patterns. J Am Chem Soc 2012;134:247-55

[172] Chen T, Luque A, Lee S, Anderson S, Segura T, Iruela-Arispe M. Anchorage of VEGF to the extracellular matrix conveys differential signaling responses to endothelial cells. J Cell Biol 2010;188:595-609.

[173] de Graaf AJ, Kooijman M, Hennink WE, Mastrobattista E. Nonnatural amino acids for site-specific protein conjugation. Bioconjugate Chem 2009;20:1281-95.

[174] Hermanson GT. Bioconjugate techniques. 2nd ed. Amsterdam: Elsevier; 2008. p. 1323.

[175] Aizawa Y, Leipzig N, Zahir T, Shoichet M. The effect of immobilized platelet derived growth factor AA on neural stem/progenitor cell differentiation on cell-adhesive hydrogels. Biomaterials 2008;29:4676-83.

[176] Leipzig N, Xu C, Zahir T, Shoichet M. Functional immobilization of interferon-gamma induces neuronal differentiation of neural stem cells. J Biomed Mater Res Part A 2010;93:625-33.

[177] Roberts MJ, Bentley MD, Harris JM. Chemistry for peptide and protein PEGylation. Adv Drug Deliv Rev 2002;54:459-76.

[178] Sejwal P, Narasimhan SK, Prashar D, Bandyopadhyay D, Luk YY Selective immobilization of peptides exclusively via $\mathrm{N}$-terminus cysteines by water-driven reactions on surfaces. J Org Chem 2009;74:6843-6.

[179] Carrico I. Chemoselective modification of proteins: hitting the target. Chem Soc Rev 2008;37:1423-31.

[180] Gauthier M, Klok HA. Peptide/protein-polymer conjugates: synthetic strategies and design concepts. Chem Commun 2008:2591-611.

[181] Phelps E, Enemchukwu N, Fiore V, Sy J, Murthy N, Sulchek T, Barker T, García A. Maleimide cross-linked bioactive PEG hydrogel exhibits improved reaction kinetics and cross-linking for cell encapsulation and in situ delivery. Adv Mater 2012;24:64-70.
[182] Ichinose J, Morimatsu M, Yanagida T, Sako Y. Covalent immobilization of epidermal growth factor molecules for singlemolecule imaging analysis of intracellular signaling. Biomaterials 2006;27:3343-50.

[183] Lösel R, Grafahrend D, Möller M, Klee D. Bioresorbable electrospun fibers for immobilization of thiol-containing compounds. Macromol Biosci 2010;10:1177-83.

[184] Fairbanks BD, Schwartz MP, Halevi AE, Nuttelman CR, Bowman CN, Anseth KS. A versatile synthetic extracellular matrix mimic via thiol-norbornene photopolymerization. Adv Mater 2009;21:5005-10.

[185] Gujraty K, Ashton R, Bethi S, Kate S, Faulkner C, Jennings G, Kane R. Thiol-mediated anchoring of ligands to self-assembled monolayers for studies of biospecific interactions. Langmuir 2006;22:10157-62.

[186] Stenzel MH. Bioconjugation using thiols: old chemistry rediscovered to connect polymers with nature's building blocks. ACS Macro Lett 2013;2:14-8.

[187] Hoyle C, Lowe A, Bowman C. Thiol-click chemistry: a multifaceted toolbox for small molecule and polymer synthesis. Chem Soc Rev 2010;39:1355-87.

[188] Ban H, Gavrilyuk J, Barbas C. Tyrosine bioconjugation through aqueous ene-type reactions: a click-like reaction for tyrosine. J Am Chem Soc 2010;132:1523-5.

[189] Vashi A, Ramshaw J, Glattauer V, Elvin C, Lyons R, Werkmeister J. Controlled surface modification of tissue culture polystyrene for selective cell binding using resilin-inspired polypeptides. Biofabrication 2013;5, 035005/1-9.

[190] Barbucci R, Magnani A, Chiumiento A, Pasqui D, Cangioli I, Lamponi S. Fibroblast cell behavior on bound and adsorbed fibronectin onto hyaluronan and sulfated hyaluronan substrates. Biomacromolecules 2005:6:638-45.

[191] Ho J, Chung E, Wall S, Schaffer D, Healy K. Immobilized sonic hedgehog N-terminal signaling domain enhances differentiation of bone marrow-derived mesenchymal stem cells. J Biomed Mater Res Part A 2007;83:1200-8.

[192] Backer M, Patel V, Jehning B, Claffey K, Backer J. Surface immobilization of active vascular endothelial growth factor via a cysteine-containing tag. Biomaterials 2006;27:5452-8.

[193] Zisch AH, Lutolf MP, Ehrbar M, Raeber GP, Rizzi SC, Davies N, Schmökel H, Bezuidenhuit D, Djonov V, Zilla P, Hubbell JA. Cell-demanded release of VEGF from synthetic, biointeractive cell-ingrowth matrices for vascularized tissue growth. FASEB J 2003; $17: 2260-2$.

[194] Sletten E, Bertozzi C. Bioorthogonal chemistry: fishing for selectivity in a sea of functionality. Angew Chem Int Ed 2009;48: 6974-98.

[195] Johnson J, Lu Y, Van Deventer J, Tirrell D. Residue-specific incorporation of non-canonical amino acids into proteins: recent developments and applications. Curr Opin Chem Biol 2010;14: 774-80.

[196] Rabuka D. Chemoenzymatic methods for site-specific protein modification. Curr Opin Chem Biol 2010;14:790-6.

[197] Carrico I, Carlson B, Bertozzi C. Introducing genetically encoded aldehydes into proteins. Nat Chem Biol 2007;3:321-2.

[198] Gilmore J, Scheck R, Esser-Kahn A, Joshi N, Francis M. N-terminal protein modification through a biomimetic transamination reaction. Angew Chem Int Ed 2006;45:5307-11.

[199] Duckworth BP, Xu J, Taton TA, Guo A, Distefano MD. Site-specific, covalent attachment of proteins to a solid surface. Bioconjugate Chem 2006;17:967-74.

[200] Sun XL, Stabler C, Cazalis C, Chaikof E. Carbohydrate and protein immobilization onto solid surfaces by sequential Diels-Alder and azide-alkyne cycloadditions. Bioconjugate Chem 2006;17: $52-7$.

[201] Leipzig ND, Wylie RG, Kim H, Shoichet MS. Differentiation of neura stem cells in three-dimensional growth factor-immobilized chitosan hydrogel scaffolds. Biomaterials 2011;32:57-64.

[202] Carrico I, Maskarinec S, Heilshorn S, Mock M, Liu J, Nowatzki P, Franck C, Ravichandran G, Tirrell D. Lithographic patterning of photoreactive cell-adhesive proteins. J Am Chem Soc 2007:129:4874-5.

[203] Ogiwara K, Nagaoka M, Cho CS, Akaike T. Effect of photoimmobilization of epidermal growth factor on the cellular behaviors. Biochem Biophys Res Commun 2006:345:255-9.

[204] Zhang K, Diehl M, Tirrell D. Artificial polypeptide scaffold for protein immobilization. J Am Chem Soc 2005;127:10136-7.

[205] de Araújo A, Palomo J, Cramer J, Köhn M, Schröder H, Wacker R, Niemeyer C, Alexandrov K, Waldmann H. Diels-Alder ligation 
and surface immobilization of proteins. Angew Chem Int Ed 2005;45:296-301.

[206] Doran MR, Markway BD, Croll TI, Sara S, Munro TP, Cooper-White JJ. Controlled presentation of recombinant proteins via a zinc-binding peptide-linker in two and three dimensional formats. Biomaterials 2009;30:6614-20.

[207] Nakaji-Hirabayashi T, Kato K, Iwata H. Improvement of neural stem cell survival in collagen hydrogels by incorporating laminin-derived cell adhesive polypeptides. Bioconjugate Chem 2012;23:212-21.

[208] Hiraoka M, Kato K, Nakaji-Hirabayashi T, Iwata H. Enhanced survival of neural cells embedded in hydrogels composed of collagen and laminin-derived cell adhesive peptide. Bioconjugate Chem 2009;20:976-83.

[209] Konagaya S, Kato K, Nakaji-Hirabayashi T, Iwata H. Design of culture substrates for large-scale expansion of neural stem cells. Biomaterials 2011;32:992-1001.

[210] Wylie R, Shoichet M. Three-dimensional spatial patterning of proteins in hydrogels. Biomacromolecules 2011;12:3789-96.

[211] Wylie RG, Ahsan S, Aizawa Y, Maxwell KL, Morshead CM, Shoichet MS. Spatially controlled simultaneous patterning of multiple growth factors in three-dimensional hydrogels. Nat Mater 2011;10:799-806.

[212] Nimmo C, Shoichet M. Regenerative biomaterials that "click": simple, aqueous-based protocols for hydrogel synthesis, surface immobilization, and 3D patterning. Bioconjugate Chem 2011;22:2199-209.

[213] Nandivada H, Jiang X, Lahann J. Click chemistry: versatility and control in the hands of materials scientists. Adv Mater 2007; 19:2197-208.

[214] Kolb H, Finn M, Sharpless K. Click chemistry: diverse chemical function from a few good reactions. Angew Chem Int Ed 2001;40:2004-21.

[215] Gallant N, Lavery K, Amis E, Becker M. Universal gradient substrates for "Click" biofunctionalization. Adv Mater 2007;19:965-9.

[216] Lutz JF, Börner HG, Weichenhan K. Combining ATRP and "Click" chemistry: a promising platform toward functional biocompatible polymers and polymer bioconjugates. Macromolecules 2006;39:6376-83.

[217] Ameringer T, Ercole F, Tsang KM, Coad BR, Hou X, Rodda A, Nisbet DR, Thissen H, Evans RA, Meagher L, Forsythe JS. Surface grafting of electrospun fibers using ATRP and RAFT for the control of biointerfacial interactions. Biointerphases 2013, 8/1-11.

[218] Evans RA. The rise of azide-alkyne 1,3-dipolar 'Click' cycloaddition and its application to polymer science and surface modification. Aust J Chem 2007;60:384-95.

[219] DeForest C, Polizzotti B, Anseth K. Sequential click reactions for synthesizing and patterning three-dimensional cell microenvironments. Nat Mater 2009;8:659-64.

[220] Tasdelen MA. Diels-Alder "click" reactions: recent applications in polymer and material science. Polym Chem 2011;2: 2133-45.

[221] Shoichet MS, Yuan Y, Shi M, Wosnick J. Method of biomolecule immobilization on polymers using click-type chemistry. US Pat Appl 2009/0297609 A1; 2009.

[222] Yousaf MN, Mrksich M. Diels-Alder reaction for the selective immobilization of protein to electroactive self-assembled monolayers. J Am Chem Soc 1999;121:4286-7.

[223] Dillmore W, Yousaf M, Mrksich M. A photochemical method for patterning the immobilization of ligands and cells to self-assembled monolayers. Langmuir 2004;20:7223-31.

[224] Yousaf M, Houseman B, Mrksich M. Using electroactive substrates to pattern the attachment of two different cell populations. Proc Natl Acad Sci U S A 2001;98:5992-6.

[225] Chan E, Yousaf M. Immobilization of ligands with precise control of density to electroactive surfaces. J Am Chem Soc 2006;128:15542-6.

[226] Chan E, Yousaf M. Site-selective immobilization of ligands with control of density on electroactive microelectrode arrays. ChemPhysChem 2007;8:1469-72.

[227] Chan E, Yousaf M. A photo-electroactive surface strategy for immobilizing ligands in patterns and gradients for studies of cell polarization. Mol Biosyst 2008;4:746-53.

[228] Hoover D, Chan E, Yousaf M. Asymmetric peptide nanoarray surfaces for studies of single cell polarization. J Am Chem Soc 2008;130:3280-1.

[229] Hoover DK, Lee Ej, Chan EWL, Yousaf MN. Electroactive nanoarrays for biospecific ligand mediated studies of cell adhesion. Chembiochem 2007;8:1920-3.
[230] Pauloehrl T, Delaittre G, Bruns M, Meißler M, Börner H, Bastmeyer M, Barner-Kowollik C. (Bio)molecular surface patterning by phototriggered oxime ligation. Angew Chem Int Ed 2012;51:9181-4.

[231] Rabuka D, Rush J, deHart G, Wu P, Bertozzi C. Site-specific chemical protein conjugation using genetically encoded aldehyde tags. Nat Protoc 2012;7:1052-67.

[232] Christman KL, Broyer RM, Tolstyka ZP, Maynard HD. Site-specific protein immobilization through $\mathrm{N}$-terminal oxime linkages. J Mater Chem 2007; 17:2021-7

[233] Dettin M, Muncan N, Bugatti A, Grezzo F, Danesin R, Rusnati M. Chemoselective surface immobilization of proteins through a cleavable peptide. Bioconjugate Chem 2011;22:1753-7.

[234] Hoffmann JC, West JL. Three-dimensional photolithographic patterning of multiple bioactive ligands in poly(ethylene glycol) hydrogels. Soft Matter 2010;6:5056-63.

[235] Azagarsamy M, Anseth K. Bioorthogonal click chemistry: an indispensable tool to create multifaceted cell culture scaffolds. ACS Macro Lett 2013;2:5-9.

[236] Jeon H, Schmidt R, Barton J, Hwang D, Gamble L, Castner D, Grigoropoulos C, Healy K. Chemical patterning of ultrathin polymer films by direct-write multiphoton lithography. J Am Chem Soc 2011;133:6138-41.

[237] Shahal T, Geiger B, Dunlop I, Spatz J. Regulation of integrin adhesions by varying the density of substrate-bound epidermal growth factor. Biointerphases 2012;7, 23/1-11.

[238] Patel N, Padera R, Sanders G, Cannizzaro S, Davies M, Langer R, Roberts C, Tendler S, Williams P, Shakesheff K. Spatially controlled cell engineering on biodegradable polymer surfaces. FASEB J 1998; 12:1447-54

[239] Christman K, Schopf E, Broyer R, Li R, Chen Y, Maynard H. Positioning multiple proteins at the nanoscale with electron beam cross-linked functional polymers. J Am Chem Soc 2009;131: 521-7.

[240] Schmidt R, Healy K. Effect of avidin-like proteins and biotin modification on mesenchymal stem cell adhesion. Biomaterials 2013;34:3758-62.

[241] Konagaya S, Kato K, Nakaji-Hirabayashi T, Arima Y, Iwata H. Array-based functional screening of growth factors toward optimizing neural stem cell microenvironments. Biomaterials 2011;32:5015-22.

[242] Nakaji-Hirabayashi T, Kato K, Arima Y, Iwata H. Oriented immobilization of epidermal growth factor onto culture substrates for the selective expansion of neural stem cells. Biomaterials 2007;28:3517-29.

[243] Dubey M, Emoto K, Takahashi H, Castner D, Grainger D. Affinitybased protein surface pattern formation by ligand self-selection from mixed protein solutions. Adv Funct Mater 2009;19:3046-55.

[244] Egawa E, Kato K, Hiraoka M, Nakaji-Hirabayashi T, Iwata H. Enhanced proliferation of neural stem cells in a collagen hydrogel incorporating engineered epidermal growth factor. Biomaterials 2011;32:4737-43.

[245] Nishi N, Matsushita O, Yuube K, Miyanaka H, Okabe A, Wada F. Collagen-binding growth factors: production and characterization of functional fusion proteins having a collagen-binding domain. Proc Natl Acad Sci U S A 1998;95:7018-23.

[246] Meyers S, Khoo X, Huang X, Walsh E, Grinstaff M, Kenan D. The development of peptide-based interfacial biomaterials for generating biological functionality on the surface of bioinert materials. Biomaterials 2009;30:277-86

[247] Meyers SR, Kenan DJ, Khoo X, Grinstaff MW. Bioactive stent surface coating that promotes endothelialization while preventing platelet adhesion. Biomacromolecules 2011;12:533-9.

[248] Huang X, Zauscher S, Klitzman B, Truskey GA, Reichert WM, Kenan DJ, Grinstaff MW. Peptide interfacial biomaterials improve endothelial cell adhesion and spreading on synthetic polyglycolic acid materials. Ann Biomed Eng 2010;38:1965-76.

[249] Sanghvi AB, Miller KPH, Belcher AM, Schmidt CE. Biomaterials functionalization using a novel peptide that selectively binds to a conducting polymer. Nat Mater 2005;4:496-502.

[250] Forciniti L, Schmidt C, Zaman M. Computational model provides insight into the distinct responses of neurons to chemical and topographical cues. Ann Biomed Eng 2009;37:363-74.

[251] Rowlands A, George P, Cooper-White J. Directing osteogenic and myogenic differentiation of MSCs: interplay of stiffness and adhesive ligand presentation. Am J Physiol Cell Physiol 2008;295:C1037-44.

[252] Luo Y, Shoichet M. A photolabile hydrogel for guided threedimensional cell growth and migration. Nat Mater 2004;3: 249-53. 
[253] Xu FJ, Li HZ, Li J, Teo YHE, Zhu CX, Kang ET, Neoh KG. Spatially well-defined binary brushes of poly(ethylene glycol)s for micropatterning of active proteins on anti-fouling surfaces. Biosens Bioelectron 2008;24:773-80.

[254] Lavanant L, Pullin B, Hubbell J, Klok HA. A facile strategy for the modification of polyethylene substrates with non-fouling, bioactive poly(poly(ethylene glycol) methacrylate) brushes. Macromol Biosci 2010;10:101-8.

[255] Tugulu S, Silacci P, Stergiopulos N, Klok HA. RGD-functionalized polymer brushes as substrates for the integrin specific adhesion of human umbilical vein endothelial cells. Biomaterials 2007;28:2536-46.

[256] Lee B, Chi Y, Lee K-B, Kim YG, Choi I. Functionalization of poly(oligo(ethylene glycol) methacrylate) films on gold and $\mathrm{Si} / \mathrm{SiO}_{2}$ for immobilization of proteins and cells: SPR and QCM studies. Biomacromolecules 2007;8:3922-9.

[257] Ren X, Wu Y, Cheng Y, Ma H, Wei S. Fibronectin and bone morphogenetic protein-2-decorated poly(OEGMA-r-HEMA) brushes promote osseointegration of titanium surfaces. Langmuir 2011;27:12069-73.

[258] Alberti K, Davey R, Onishi K, George S, Salchert K, Seib F, Bornhäuser M, Pompe T, Nagy A, Werner C, Zandstra P. Functional immobilization of signaling proteins enables control of stem cell fate. Nat Methods 2008;5:645-50.

[259] Xu F, Wang Z, Yang W. Surface functionalization of polycaprolactone films via surface-initiated atom transfer radical polymerization for covalently coupling cell-adhesive biomolecules. Biomaterials 2010;31:3139-47.

[260] Xu F, Zhong S, Yung L, Tong Y, Kang E, Neoh K. Collagencoupled poly(2-hydroxyethyl methacrylate)-Si(111) hybrid surfaces for cell immobilization. Tissue Eng 2005;11: $1736-48$.

[261] Alang Ahmad S, Hucknall A, Chilkoti A, Leggett G. Protein patterning by UV-induced photodegradation of poly(oligo(ethylene glycol) methacrylate) brushes. Langmuir 2010;26: 9937-42.

[262] Grafahrend D, Heffels KH, Beer M, Gasteier P, Möller M, Boehm G Dalton P, Groll J. Degradable polyester scaffolds with controlled surface chemistry combining minimal protein adsorption with specific bioactivation. Nat Mater 2011;10:67-73.

[263] DeForest CA, Anseth KS. Photoreversible patterning of biomolecules within click-based hydrogels. Angew Chem 2012;124:1852-5.

[264] Arnold M, Cavalcanti-Adam E, Glass R, Blümmel J, Eck W, Kantlehner M, Kessler H, Spatz J. Activation of integrin function by nanopatterned adhesive interfaces. ChemPhysChem 2004;5:383-8.

[265] Aydin D, Louban I, Perschmann N, Blümmel J, Lohmüller T, Cavalcanti-Adam E, Haas T, Walczak H, Kessler H, Fiammengo R, Spatz J. Polymeric substrates with tunable elasticity and nanoscopically controlled biomolecule presentation. Langmuir 2010;26:15472-80.

[266] Cavalcanti-Adam E, Volberg T, Micoulet A, Kessler H, Geiger B, Spatz $\mathrm{J}$. Cell spreading and focal adhesion dynamics are regulated by spacing of integrin ligands. Biophys J 2007;92:2964-74.

[267] Deeg J, Louban I, Aydin D, Selhuber-Unkel C, Kessler H, Spatz J. Impact of local versus global ligand density on cellular adhesion. Nano Lett 2011;11:1469-76.

[268] Selhuber-Unkel C, Erdmann T, López-García M, Kessler H, Schwarz U, Spatz J. Cell adhesion strength is controlled by intermolecular spacing of adhesion receptors. Biophys J 2010;98: 543-51.

[269] Beer MV, Rech C, Gasteier P, Sauerzapfe B, Salber J, Ewald A, Möller M, Elling L, Groll J. The next step in biomimetic material design: poly-LacNAc-mediated reversible exposure of extra cellular matrix components. Adv Healthc Mater 2012;2:306-11.

[270] Park S, Yousaf M. An interfacial oxime reaction to immobilize ligands and cells in patterns and gradients to photoactive surfaces. Langmuir 2008;24:6201-7.

[271] Hahn M, Taite L, Moon J, Rowland M, Ruffino K, West J. Photolithographic patterning of polyethylene glycol hydrogels. Biomaterials 2006;27:2519-24.

[272] Hoffmann J, West J. Three-dimensional photolithographic micropatterning: a novel tool to probe the complexities of cell migration. Integr Biol 2013;5:817-27.

[273] Lee SH, Moon J, West J. Three-dimensional micropatterning of bioactive hydrogels via two-photon laser scanning photolithography for guided 3D cell migration. Biomaterials 2008;29: 2962-8.
[274] Kim DH, Lee H, Lee Y, Nam JM, Levchenko A. Biomimetic nanopatterns as enabling tools for analysis and control of live cells. Adv Mater 2010;22:4551-66

[275] Théry M. Micropatterning as a tool to decipher cell morphogenesis and functions. J Cell Sci 2010;123:4201-13.

[276] Arnold M, Hirschfeld-Warneken V, Lohmüller T, Heil P, Blümmel J, Cavalcanti-Adam E, López-García M, Walther P, Kessler H, Geiger $\mathrm{B}$, Spatz J. Induction of cell polarization and migration by a gradient of nanoscale variations in adhesive ligand spacing. Nano Lett 2008;8:2063-9.

[277] Moore K, MacSween M, Shoichet M. Immobilized concentration gradients of neurotrophic factors guide neurite outgrowth of primary neurons in macroporous scaffolds. Tissue Eng $2006 ; 12: 267-78$.

[278] Telford A, Meagher L, Glattauer V, Gengenbach T, Easton C, Neto C. Micropatterning of polymer brushes: grafting from dewetting polymer films for biological applications. Biomacromolecules 2012;13:2989-96.

[279] Zorlutuna P, Annabi N, Camci-Unal G, Nikkhah M, Cha J, Nichol J, Manbachi A, Bae H, Chen S, Khademhosseini A. Microfabricated biomaterials for engineering 3D tissues. Adv Mater 2012;24:1782-804.

[280] Christman KL, Enriquez-Rios VD, Maynard HD. Nanopatterning proteins and peptides. Soft Matter 2006;2:928-39.

[281] Ekblad T, Liedberg B. Protein adsorption and surface patterning. Curr Opin Colloid Interface Sci 2010;15:499-509.

[282] Wheeldon I, Farhadi A, Bick A, Jabbari E, Khademhosseini A. Nanoscale tissue engineering: spatial control over cell-materials interactions. Nanotechnology 2011, 22/212001/1-16.

[283] Falconnet D, Csucs G, Grandin H, Textor M. Surface engineering approaches to micropattern surfaces for cell-based assays. Biomaterials 2006;27:3044-63.

[284] Ross AM, Lahann J. Surface engineering the cellular microenvironment via patterning and gradients. J Polym Sci Part B Polym Phys 2013;51:775-94.

[285] Qin D, Xia Y, Whitesides G. Soft lithography for micro- and nanoscale patterning. Nat Protoc 2010;5:491-502.

[286] Kane R, Takayama S, Ostuni E, Ingber D, Whitesides G. Patterning proteins and cells using soft lithography. Biomaterials 1999;20:2363-76.

[287] Ruiz SA, Chen CS. Microcontact printing: a tool to pattern. Soft Matter 2007;3:168-77.

[288] Csucs G, Künzler T, Feldman K, Robin F, Spencer ND. Microcontact printing of macromolecules with submicrometer resolution by means of polyolefin stamps. Langmuir 2003;19: 6104-9

[289] Faia-Torres AB, Goren T, Textor M, Pla-Roca M. Patterned biointerfaces. In: Ducheyne P, Healy K, Hutmacher D, Grainger DW, Kirkpatrick CJ, editors. Comprehensive biomaterials, vol. 4. Amsterdam: Elsevier Sci; 2011. p. 181-201.

[290] Chen C, Mrksich M, Huang S, Whitesides G, Ingber D. Geometric control of cell life and death. Science 1997;276:1425-8.

[291] Lehnert D, Wehrle-Haller B, David C, Weiland U, Ballestrem C, Imhof B, Bastmeyer M. Cell behaviour on micropatterned substrata: limits of extracellular matrix geometry for spreading and adhesion. J Cell Sci 2004;117:41-52.

[292] Coyer S, Delamarche E, García A. Protein tethering into multiscale geometries by covalent subtractive printing. Adv Mater 2011;23:1550-3.

[293] Coyer S, Singh A, Dumbauld D, Calderwood D, Craig S, Delamarche E, García A. Nanopatterning reveals an ECM area threshold for focal adhesion assembly and force transmission that is regulated by integrin activation and cytoskeleton tension. J Cell Sci 2012;125:5110-23.

[294] Kilian K, Bugarija B, Lahn B, Mrksich M. Geometric cues for directing the differentiation of mesenchymal stem cells. Proc Natl Acad Sci U S A 2010;107:4872-7.

[295] Xia N, Thodeti C, Hunt T, Xu Q, Ho M, Whitesides G, Westervelt R, Ingber D. Directional control of cell motility through focal adhesion positioning and spatial control of Rac activation. FASEB J 2008;22:1649-59.

[296] von Philipsborn A, Lang S, Bernard A, Loeschinger J, David C, Lehnert D, Bastmeyer M, Bonhoeffer F. Microcontact printing of axon guidance molecules for generation of graded patterns. Nat Protoc 2006;1:1322-8.

[297] Blawas A, Reichert W. Protein patterning. Biomaterials 1998;19:595-609.

[298] Kim M, Choi JC, Jung HR, Katz J, Kim MG, Doh J. Addressable micropatterning of multiple proteins and cells by microscope 
projection photolithography based on a protein friendly photoresist. Langmuir 2010;26:12112-8.

[299] Nakanishi J, Kikuchi Y, Takarada T, Nakayama H, Yamaguchi K, Maeda M. Spatiotemporal control of cell adhesion on a selfassembled monolayer having a photocleavable protecting group. Anal Chim Acta 2006;578:100-4.

[300] Adzima B, Tao Y, Kloxin C, DeForest C, Anseth K, Bowman C. Spatial and temporal control of the alkyne-azide cycloaddition by photoinitiated Cu(II) reduction. Nat Chem 2011;3:256-9.

[301] Doyle A, Wang F, Matsumoto K, Yamada K. One-dimensional topography underlies three-dimensional fibrillar cell migration.J Cell Biol 2009; $184: 481-90$.

[302] Bélisle J, Kunik D, Costantino S. Rapid multicomponent optical protein patterning. Lab Chip 2009;9:3580-5.

[303] Kolodziej CM, Maynard HD. Electron-beam lithography for patterning biomolecules at the micron and nanometer scale. Chem Mater 2012;24:774-80.

[304] Pesen D, Haviland D. Modulation of cell adhesion complexes by surface protein patterns. ACS Appl Mater Interfaces 2009;1: 543-8.

[305] Krsko P, McCann T, Thach TT, Laabs T, Geller H, Libera M. Lengthscale mediated adhesion and directed growth of neural cells by surface-patterned poly(ethylene glycol) hydrogels. Biomaterials 2009;30:721-9.

[306] Rundqvist J, Mendoza B, Werbin J, Heinz W, Lemmon C, Romer L, Haviland D, Hoh J. High fidelity functional patterns of an extracellular matrix protein by electron beam-based inactivation. J Am Chem Soc 2007;129:59-67.

[307] Salaita K, Wang Y, Mirkin C. Applications of dip-pen nanolithography. Nat Nanotechnol 2007;2:145-55.

[308] Wu CC, Reinhoudt D, Otto C, Subramaniam V, Velders A. Strategies for patterning biomolecules with dip-pen nanolithography. Small 2011;7:989-1002.

[309] Lee KB, Park SJ, Mirkin C, Smith J, Mrksich M. Protein nanoarrays generated by dip-pen nanolithography. Science 2002;295: 1702-5.

[310] Wilson DL, Martin R, Hong S, Cronin-Golomb M, Mirkin CA, Kaplan DL. Surface organization and nanopatterning of collagen by dip-pen nanolithography. Proc Natl Acad Sci U S A 2001;98:13660-4.

[311] Wadu-Mesthrige K, Amro N, Garno J, Xu S, Liu G. Fabrication of nanometer-sized protein patterns using atomic force microscopy and selective immobilization. Biophys J 2001;80:1891-9.

[312] Sekula S, Fuchs J, Weg-Remers S, Nagel P, Schuppler S, Fragala J, Theilacker N, Franzreb M, Wingren C, Ellmark P, Borrebaeck C, Mirkin C, Fuchs H, Lenhert S. Multiplexed lipid dip-pen nanolithography on subcellular scales for the templating of functional proteins and cell culture. Small 2008;4:1785-93.

[313] Agheli H, Malmström J, Larsson E, Textor M, Sutherland D. Large area protein nanopatterning for biological applications. Nano Lett 2006;6:1165-71.

[314] Malmström J, Christensen B, Jakobsen H, Lovmand J, Foldbjerg R, Sørensen E, Sutherland D. Large area protein patterning reveals nanoscale control of focal adhesion development. Nano Lett 2010;10:686-94

[315] Malmström J, Lovmand J, Kristensen S, Sundh M, Duch M, Sutherland D. Focal complex maturation and bridging on $200 \mathrm{~nm}$ vitronectin but not fibronectin patches reveal different mechanisms of focal adhesion formation. Nano Lett 2011;11:2264-71.

[316] Slater J, Frey W. Nanopatterning of fibronectin and the influence of integrin clustering on endothelial cell spreading and proliferation. J Biomed Mater Res Part A 2008;87:176-95.

[317] Kong H, Hsiong S, Mooney D. Nanoscale cell adhesion ligand presentation regulates nonviral gene delivery and expression. Nano Lett 2007:7:161-6.

[318] Lee KY, Alsberg E, Hsiong S, Comisar W, Linderman J, Ziff R, Mooney D. Nanoscale adhesion ligand organization regulates osteoblast proliferation and differentiation. Nano Lett 2004;4:1501-6.

[319] Koo L, Irvine D, Mayes A, Lauffenburger D, Griffith L. Co-regulation of cell adhesion by nanoscale RGD organization and mechanical stimulus. J Cell Sci 2002;115:1423-33.

[320] Maheshwari G, Brown G, Lauffenburger D, Wells A, Griffith L. Cell adhesion and motility depend on nanoscale RGD clustering. J Cell Sci 2000;113:1677-86

[321] George P, Doran M, Croll T, Munro T, Cooper-White J. Nanoscale presentation of cell adhesive molecules via block copolymer selfassembly. Biomaterials 2009;30:4732-7.

[322] Frith J, Mills R, Cooper-White J. Lateral spacing of adhesion peptides influences human mesenchymal stem cell behaviour. J Cell Sci 2012;125:317-27
[323] Wei C, Dong J. Direct fabrication of high-resolution threedimensional polymeric scaffolds using electrohydrodynamic hot jet plotting. J Micromech Microeng 2013;23:025017.

[324] Lam J, Segura T. The modulation of MSC integrin expression by RGD presentation. Biomaterials 2013;34:3938-47.

[325] Ochsenhirt SE, Kokkoli E, McCarthy JB, Tirrell M. Effect of RGD secondary structure and the synergy site PHSRN on cell adhesion, spreading and specific integrin engagement. Biomaterials 2006;27:3863-74.

[326] Benoit DSW, Anseth KS. The effect on osteoblast function of colocalized RGD and PHSRN epitopes on PEG surfaces. Biomaterials 2005;26:5209-20.

[327] Ebara M, Yamato M, Aoyagi T, Kikuchi A, Sakai K, Okano T. A novel approach to observing synergy effects of PHSRN on integrinRGD binding using intelligent surfaces. Adv Mater 2008;20: 3034-8

[328] Mardilovich A, Craig J, McCammon M, Garg A, Kokkoli E. Design of a novel fibronectin-mimetic peptide-amphiphile for functionalized biomaterials. Langmuir 2006;22:3259-64.

[329] Kisiel M, Martino M, Ventura M, Hubbell J, Hilborn J, Ossipov D. Improving the osteogenic potential of BMP-2 with hyaluronic acid hydrogel modified with integrin-specific fibronectin fragment. Biomaterials 2013;34:704-12.

[330] Elloumi I, Kobayashi R, Funabashi H, Mie M, Kobatake E. Construction of epidermal growth factor fusion protein with cell adhesive activity. Biomaterials 2006;27:3451-8

[331] Tibbitt M, Anseth K. Dynamic microenvironments: the fourth dimension. Sci Transl Med 2012;4, 160ps24/1-4.

[332] Lutolf M, Gilbert P, Blau H. Designing materials to direct stem-cell fate. Nature 2009;462:433-41.

[333] Kinney M, McDevitt T. Emerging strategies for spatiotemporal control of stem cell fate and morphogenesis. Trends Biotechnol 2013;31:78-84

[334] Vulic K, Shoichet M. Tunable growth factor delivery from injectable hydrogels for tissue engineering. J Am Chem Soc 2012;134: 882-5.

[335] Ashley G, Henise J, Reid R, Santi D. Hydrogel drug delivery system with predictable and tunable drug release and degradation rates. Proc Natl Acad Sci U S A 2013;110:2318-23.

[336] Kloxin A, Kasko A, Salinas C, Anseth K. Photodegradable hydrogels for dynamic tuning of physical and chemical properties. Science 2009;324:59-63.

[337] Wirkner M, Alonso J, Maus V, Salierno M, Lee T, García A, del Campo A. Triggered cell release from materials using bioadhesive photocleavable linkers. Adv Mater 2011:23:3907-10.

[338] Petersen S, Alonso J, Specht A, Duodu P, Goeldner M, del Campo A. Phototriggering of cell adhesion by caged cyclic RGD peptides. Angew Chem Int Ed 2008;47:3192-5.

[339] Wirkner M, Weis S, San Miguel V, Álvarez M, Gropeanu R, Salierno M, Sartoris A, Unger R, Kirkpatrick C, del Campo A. Photoactivatable caged cyclic RGD peptide for triggering integrin binding and cell adhesion to surfaces. ChemBioChem 2011;12:2623-9.

[340] Auernheimer J, Dahmen C, Hersel U, Bausch A, Kessler H. Photoswitched cell adhesion on surfaces with RGD peptides. J Am Chem Soc 2005; 127:16107-10.

[341] Milbradt A, Löweneck M, Krupka S, Reif M, Sinner EK, Moroder L, Renner C. Photomodulation of conformational states. IV. Integrinbinding RGD-peptides with (4-aminomethyl)phenylazobenzoic acid as backbone constituent. Biopolymers 2005;77: 304-13.

342] Schütt M, Krupka S, Milbradt A, Deindl S, Sinner E, Oesterhelt D, Renner C, Moroder L. Photocontrol of cell adhesion processes: model studies with cyclic azobenzene-RGD peptides. Chem Biol 2003:10:487-90.

[343] Todd SJ, Farrar D, Gough JE, Ulijn RV. Enzyme-triggered cell attachment to hydrogel surfaces. Soft Matter 2007;3:547-50.

[344] Liu B, Liu Y, Riesberg J, Shen W. Dynamic presentation of immobilized ligands regulated through biomolecular recognition. J Am Chem Soc 2010;132:13630-2.

[345] Chan E, Park S, Yousaf M. An electroactive catalytic dynamic substrate that immobilizes and releases patterned ligands, proteins, and cells. Angew Chem Int Ed 2008:47:6267-71.

[346] Lutolf M, Hubbell J. Synthetic biomaterials as instructive extracellular microenvironments for morphogenesis in tissue engineering. Nat Biotechnol 2005;23:47-55.

[347] Zisch AH, Ehrbar M. Cell-demanded release of growth factors. In: Ducheyne P, Healy K, Hutmacher D, Grainger DW, Kirkpatrick CI, editors. Comprehensive biomaterials, vol. 4. Amsterdam: Elsevier Sci; 2011. p. 463-73 
[348] Salinas C, Anseth K. The enhancement of chondrogenic differentiation of human mesenchymal stem cells by enzymatically regulated RGD functionalities. Biomaterials 2008;29:2370-7.

[349] Tsurkan M, Chwalek K, Levental K, Freudenberg U, Werner C. Modular StarPEG-heparin gels with bifunctional peptide linkers. Macromol Rapid Commun 2010;31:1529-33.

[350] Lee K, Silva E, Mooney D. Growth factor delivery-based tissue engineering: general approaches and a review of recent developments. J R Soc Interface 2011;8:153-70.

[351] Ehrbar M, Djonov V, Schnell C, Tschanz S, Martiny-Baron G, Schenk U, Wood J, Burri P, Hubbell J, Zisch A. Cell-demanded liberation of VEGF121 from fibrin implants induces local and controlled blood vessel growth. Circ Res 2004;94:1124-32.

[352] Sakiyama-Elbert SE. Development of growth factor fusion proteins for cell-triggered drug delivery. FASEB J 2001;15:1300-2.

[353] Schmoekel H, Weber F, Schense J, Grätz K, Schawalder P, Hubbell J. Bone repair with a form of BMP-2 engineered for incorporation into fibrin cell ingrowth matrices. Biotechnol Bioeng 2005;89: 253-62.

[354] Strehin I, Elisseeff J. Characterizing ECM production by cells encapsulated in hydrogels. Methods Mol Biol 2009;522:349-62.

[355] Noble J, Bailey M. Quantitation of protein. Methods Enzymol 2009;463:73-95.

[356] Dixon M. Quartz crystal microbalance with dissipation monitoring: enabling real-time characterization of biological materials and their interactions. J Biomol Tech 2008;19:151-8.

[357] Coad B, Lu Y, Meagher L. A substrate-independent method for surface grafting polymer layers by atom transfer radical polymerization: reduction of protein adsorption. Acta Biomater 2012;8:608-18

[358] Enemchukwu NO, García A. Peptide- and protein-modified surfaces. In: Ducheyne P, Healy K, Hutmacher D, Grainger DW Kirkpatrick CJ, editors. Comprehensive biomaterials, vol. 4. Amsterdam: Elsevier Sci; 2011. p. 145-59.

[359] Fägerstam L, Frostell-Karlsson A, Karlsson R, Persson B, Rönnberg I. Biospecific interaction analysis using surface plasmon resonance detection applied to kinetic, binding site and concentration analysis. J Chromatogr 1992;597:397-410.

[360] Nisbet D, Rodda A, Finkelstein D, Horne M, Forsythe J, Shen W. Surface and bulk characterisation of electrospun membranes: problems and improvements. Colloids Surf B 2009;71: $1-12$.

[361] Lee J, Lee JW, Schmidt C. Neuroactive conducting scaffolds: nerve growth factor conjugation on active ester-functionalized polypyrrole. J R Soc Interface 2009;6:801-10.

[362] Kingshott P, Andersson G, McArthur S, Griesser H. Surface modification and chemical surface analysis of biomaterials. Curr Opin Chem Biol 2011;15:667-76.

[363] Baio J, Cheng F, Ratner D, Stayton P, Castner D. Probing orientation of immobilized humanized anti-lysozyme variable fragment by timeof-flight secondary-ion mass spectrometry. J Biomed Mater Res Part A 2011;97:1-7.
[364] Xia N, May CJ, McArthur SL, Castner DG. Time-of-flight secondary ion mass spectrometry analysis of conformational changes in adsorbed protein films. Langmuir 2002;18:4090-7.

[365] Barnes C, Brison J, Michel R, Brown B, Castner D, Badylak S, Ratner B. The surface molecular functionality of decellularized extracellular matrices. Biomaterials 2011;32:137-43.

[366] Brown B, Barnes C, Kasick R, Michel R, Gilbert T, Beer-Stolz D, Castner D, Ratner B, Badylak S. Surface characterization of extracellular matrix scaffolds. Biomaterials 2010;31:428-37.

[367] Sawyer A, Weeks D, Kelpke S, McCracken M, Bellis S. The effect of the addition of a polyglutamate motif to RGD on peptide tethering to hydroxyapatite and the promotion of mesenchymal stem cell adhesion. Biomaterials 2005:26:7046-56.

[368] Chen PR, Chen MH, Lin FH, Su WY. Release characteristics and bioactivity of gelatin-tricalcium phosphate membranes covalently immobilized with nerve growth factors. Biomaterials 2005;26:6579-87.

[369] Oh S, Kim T, Lee J. Creating growth factor gradients in three dimensional porous matrix by centrifugation and surface immobilization. Biomaterials 2011;32:8254-60.

[370] Pakulska MM, Vulic K, Shoichet MS. Affinity-based release of chondroitinase $\mathrm{ABC}$ from a modified methylcellulose hydrogel. J Controlled Release 2013;171:11-6.

[371] Sharon J, Puleo D. Immobilization of glycoproteins, such as VEGF, on biodegradable substrates. Acta Biomater 2008;4:1016-23.

[372] Tam RY, Cooke MJ, Shoichet MS. A covalently modified hydroge blend of hyaluronan-methyl cellulose with peptides and growth factors influences neural stem/progenitor cell fate. J Mater Chem 2012:22:19402-11.

[373] Ho MH, Wang DM, Hsieh HJ, Liu HC, Hsien TY, Lai JY, Hou LT. Preparation and characterization of RGD-immobilized chitosan scaffolds. Biomaterials 2005;26:3197-206.

[374] Masuko T, Iwasaki N, Yamane S, Funakoshi T, Majima T, Minami A, Ohsuga N, Ohta T, Nishimura SI. Chitosan-RGDSGGC conjugate as a scaffold material for musculoskeletal tissue engineering. Biomaterials 2005;26:5339-47

[375] Massia S, Hubbell J. An RGD spacing of $440 \mathrm{~nm}$ is sufficient for integrin alpha $\mathrm{V}$ beta 3 -mediated fibroblast spreading and $140 \mathrm{~nm}$ for focal contact and stress fiber formation. J Cell Bio 1991;114:1089-100.

[376] Brandley BK, Schnaar RL. Tumor cell haptotaxis on covalently immobilized linear and exponential gradients of a cell adhesion peptide. Dev Biol 1989;135:74-86.

[377] Chollet C, Chanseau C, Brouillaud B, Durrieu M. RGD peptides grafting onto poly(ethylene terephthalate) with well controlled densities. Biomol Eng 2007;24:477-82.

[378] Clémence J, Ranieri J, Aebischer P, Sigrist H. Photoimmobilization of a bioactive laminin fragment and pattern-guided selective neuronal cell attachment. Bioconjugate Chem 1995;6:411-7.

[379] Barber T, Harbers G, Park S, Gilbert M, Healy K. Ligand density characterization of peptide-modified biomaterials. Biomaterials 2005;26:6897-905. 